\title{
Prevention of Significant Deterioration Permit Application for the Fueled Clad Fabrication System, the Radioisotope Power Systems Facility, and the Fuel Assembly Area
}

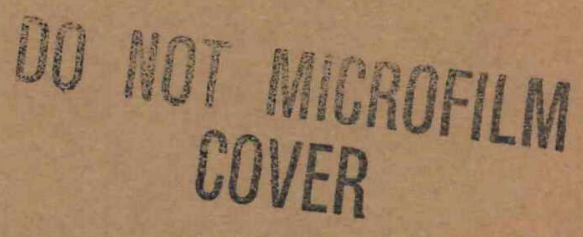

United States
Department of Energy
Fichland, Washington 


\section{DISCLAIMER}

This report was prepared as an account of work sponsored by an agency of the United States Government. Neither the United States Government nor any agency Thereof, nor any of their employees, makes any warranty, express or implied, or assumes any legal liability or responsibility for the accuracy, completeness, or usefulness of any information, apparatus, product, or process disclosed, or represents that its use would not infringe privately owned rights. Reference herein to any specific commercial product, process, or service by trade name, trademark, manufacturer, or otherwise does not necessarily constitute or imply its endorsement, recommendation, or favoring by the United States Government or any agency thereof. The views and opinions of authors expressed herein do not necessarily state or reflect those of the United States Government or any agency thereof. 


\section{DISCLAIMER}

Portions of this document may be illegible in electronic image products. Images are produced from the best available original document. 


\section{Prevention of Significant Deterioration Permit Application for the Fueled Clad Fabrication System, the Radioisotope Power Systems Facility, and the Fuel Assembly Area}

Date Published

August 1989

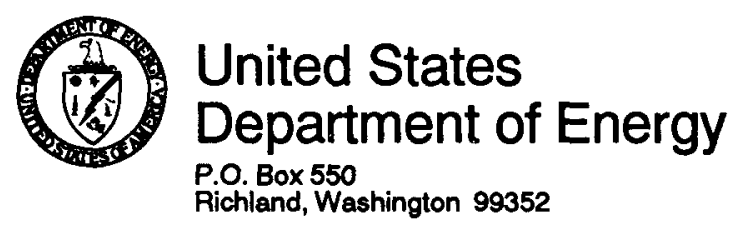




\section{CONTENTS}

Prevention of Significant Deterioration New Source Review for the Fueled Clad Fabrication System, the Radioisotope

Power Systems Facility, and the Fuel Assembly Area $\ldots \ldots \ldots \ldots \ldots \ldots \ldots$

\section{Prevention of Significant Deterioration New Source Review for Fueled Clad Facility System}

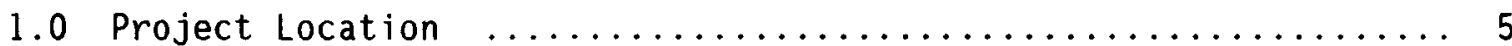

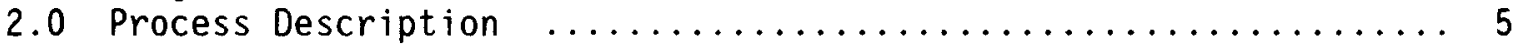

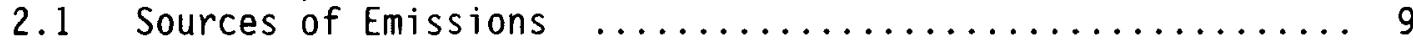

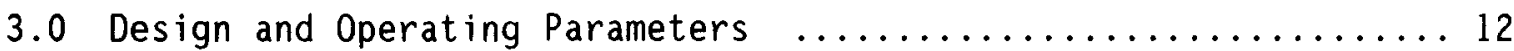

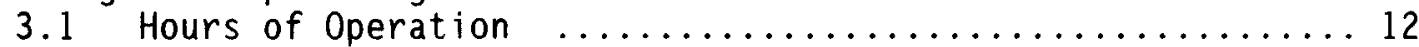

3.2 Normal and Maximum Production Rates $\ldots \ldots \ldots \ldots \ldots \ldots \ldots 12$

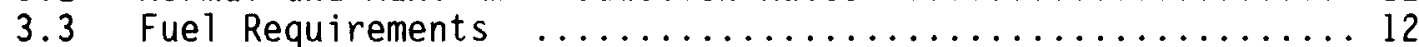

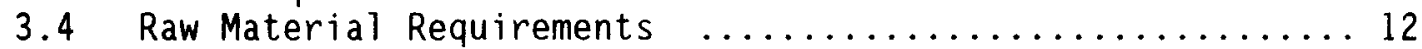

3.5 Emissions Control System ......................... 13

4.0 Emissions - Type and Quantity ........................ 14

4.1 Representative Emissions from the Existing Source ....... 14

4.2 Projected Actual Controlled Emissions ................ 14

4.3 Projected Potential Controlled Emissions ............. 16

5.0 Anticipated Construction Schedule $\ldots \ldots \ldots \ldots \ldots \ldots \ldots \ldots \ldots \ldots$

6.0 A Demonstration of Best Available Control

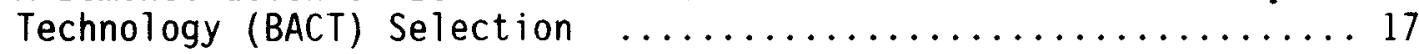

7.0 Analysis of Present Air Quality at the

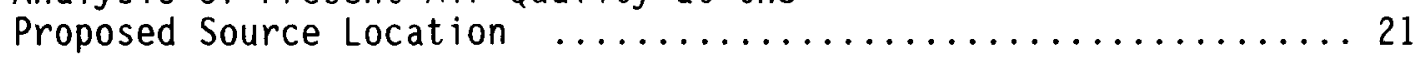

8.0 Analysis of the Proposed Source on Ambient Air Quality .......22

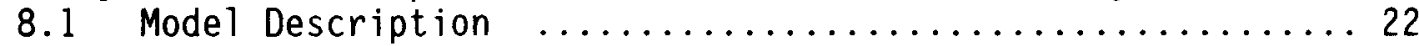

8.2 Results of Modeling Analysis $\ldots \ldots \ldots \ldots \ldots \ldots \ldots \ldots \ldots \ldots \ldots \ldots$

9.0 Demonstrate that Proposed Emissions Will Not Cause a Violation of State or National Ambient Air Quality Standards ........... 24

10.0 Demonstrate that Proposed Emissions Will Not Cause an Excursion Over PSD Increments for Particulate Matter and Sulphur Dioxide

11.0 Demonstrate that Proposed Emissions Will Not Impair Visibility in a Class I Area or Other Sensitive Areas ........ 25

12.0 Discuss the Proposed Project's Effects on Residential or Commercial Growth, Vehicular Traffic, Soils, Vegetation, Acid Deposition, and Any Other Air Quality Related Values ......... 25

References . 26 


\section{CONTENTS (continued) \\ Prevention of Significant Deterioration New Source Review for Radioisotope Power Systems Facility}

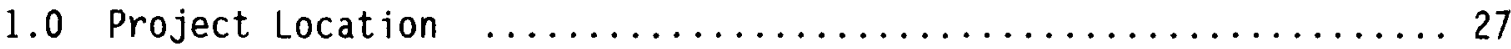

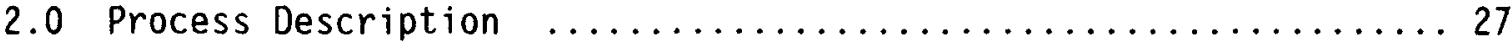

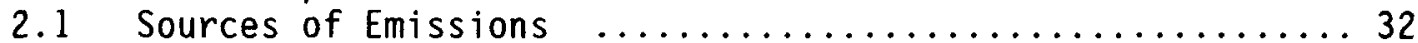

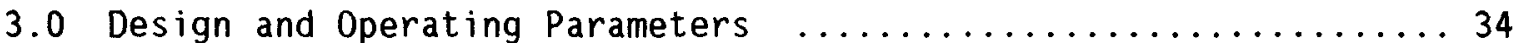

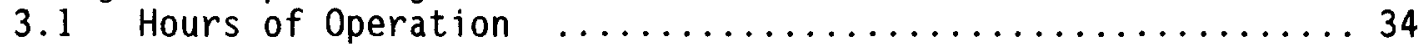

3.2 Normal and Maximum Production Rates ............... 34

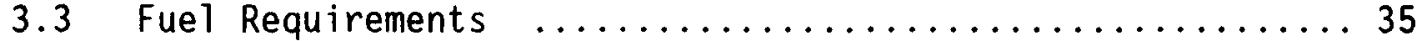

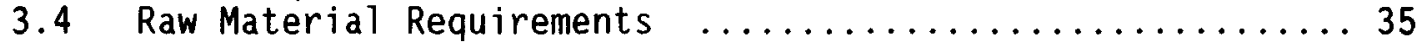

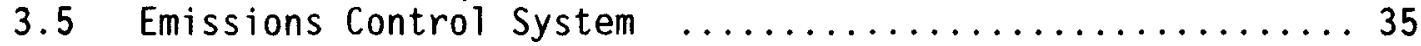

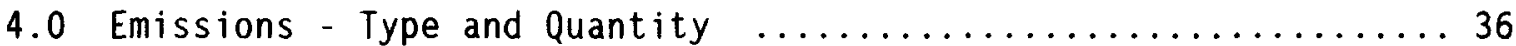

4.1 Representative Emissions from the

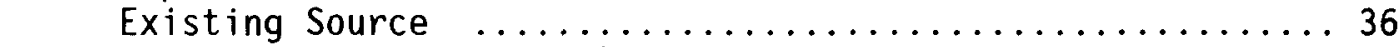

4.2 Projected Actual Controlled Emissions .............. 36

4.3 Projected Potential Controlled Emissions ............. 38

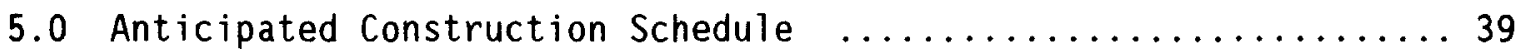

6.0 A Demonstration of Best Available Control

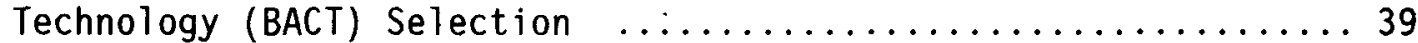

6.1 Control Alternatives ...................... 40

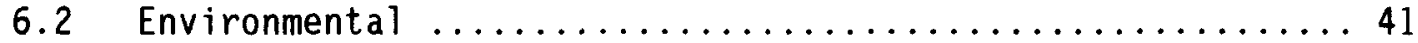

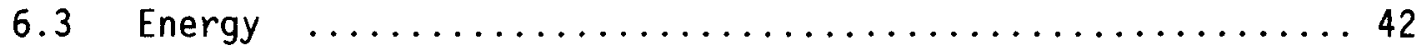

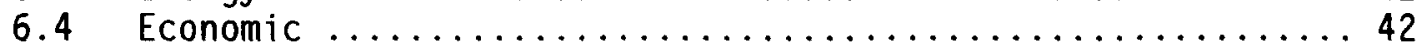

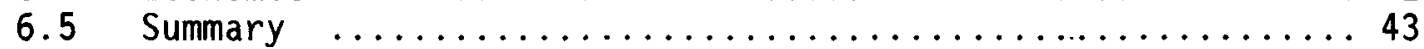

7.0 Analysis of Present Air Quality at the Proposed

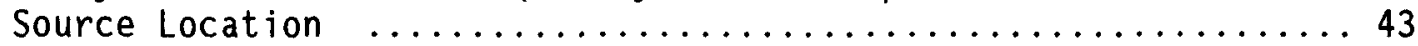

8.0 Analysis of the Proposed Source on Ambient Air Quality ......44

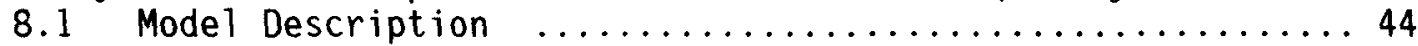

8.2 Results of Modeling Analysis $\ldots \ldots \ldots \ldots \ldots \ldots \ldots \ldots \ldots$

9.0 Demonstrate that Proposed Emissions Will Not Cause a Violation of State or National Ambient Air Quality Standards

10.0 Demonstrate that Proposed Emissions Will Not Cause an Excursion Over PSD Increments for Particulate Matter and Sulphur Dioxide

11.0 Demonstrate that Proposed Emissions Will Not Impair Visibility in a Class I Area or Other Sensitive Areas 


\section{CONTENTS (continued)}

12.0 Discuss the Proposed Project's Effects on Residential or Commercial Growth, Vehicular Traffic, Soils, Vegetation, Acid Deposition, and Any Other Air Quality Related Values ........ 46

References

\section{Prevention of Significant Deterioration New Source Review for Fuel Assembly Area}

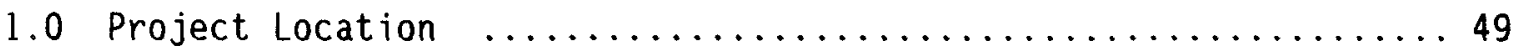

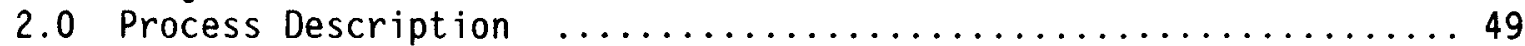

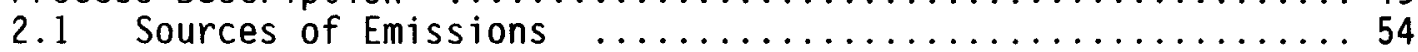

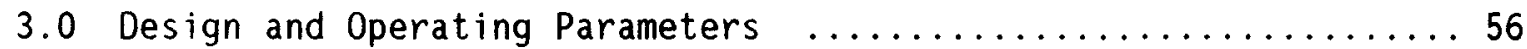

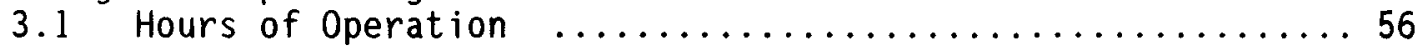

3.2 Normal and Maximum Production Rates $\ldots \ldots \ldots \ldots \ldots \ldots \ldots$

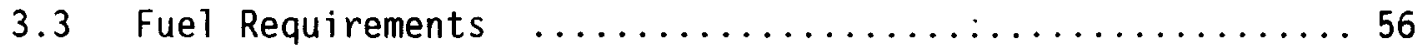

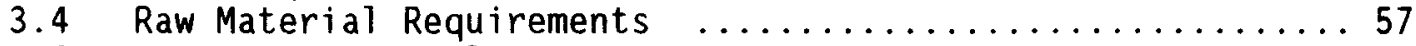

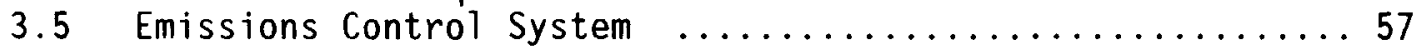

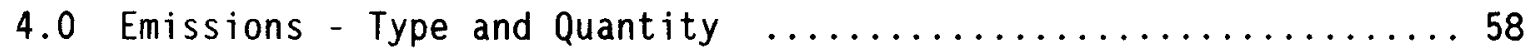

4.1 Representative Emissions from the Existing Source ........ 58

4.2 Projected Actual Controlled Emissions ............... 59

4.3 Projected Potential Controlled Emissions .............60

5.0 Anticipated Construction Schedule $\ldots \ldots \ldots \ldots \ldots \ldots \ldots \ldots \ldots \ldots \ldots \ldots \ldots$

6.0 A Demonstration of Best Available Control Technology

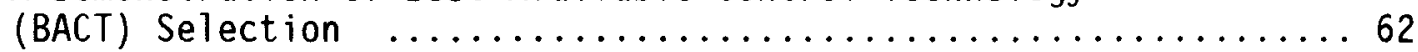

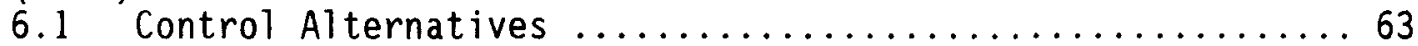

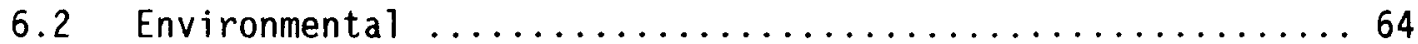

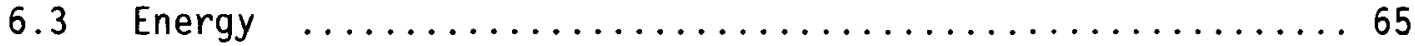

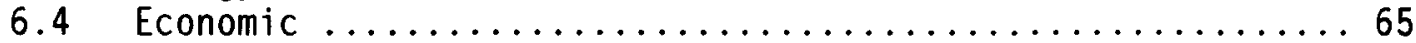

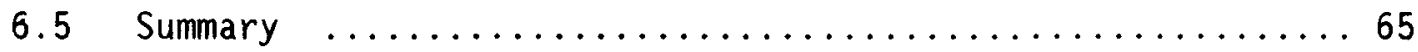

7.0 Analysis of Present Air Quality at the Proposed

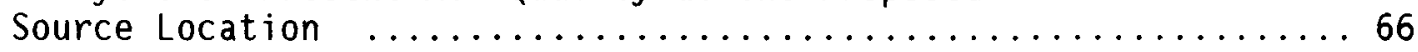

8.0 Analysis of the Proposed Source on Ambient Air Quality ......66

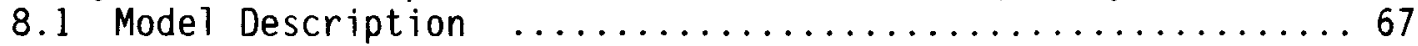

8.2 Results of Modeling Analysis $\ldots \ldots \ldots \ldots \ldots \ldots \ldots \ldots \ldots \ldots$

9.0 Demonstrate that Proposed Emissions Will Not Cause a Violation of State or National Ambient Air Quality Standards

10.0 Demonstrate that Proposed Emissions Will Not Cause an Excursion Over PSD Increments for Particulate Matter and Sulphur Dioxide 


\section{CONTENTS (continued)}

11.0 Demonstrate that Proposed Emissions Will Not Impair Visibility in a Class I Area or Other Sensitive Areas ........6 69

12.0 Discuss the Proposed Project's Effects on Residential or Commercial Growth, Vehicular Traffic, Soils, Vegetation, Acid Deposition, and Any Other

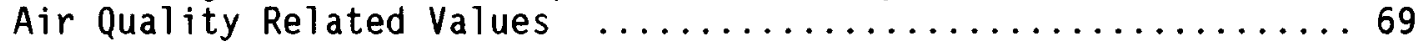

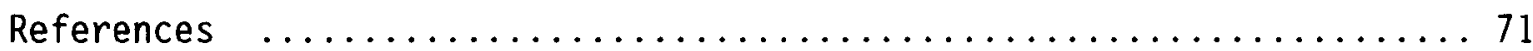




\section{LIST OF FIGURES}

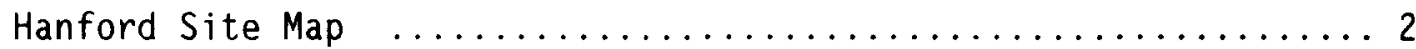

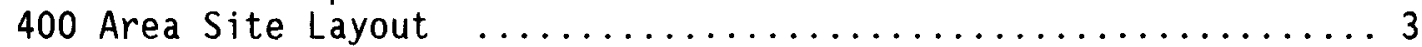

Fuels and Materials Examination Facility ................... 4

FMEF Hot Cells Located 10.7 Meters (35 Feet) Belowgrade

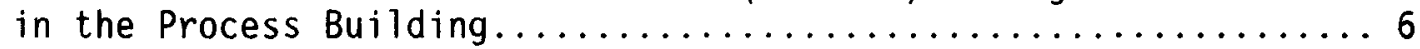

5 General Purpose Heat Source Module Assembly $\ldots \ldots \ldots \ldots \ldots \ldots \ldots 7$

6 Overall Process Flow Diagram for the Fueled Clad

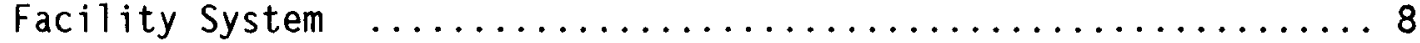

7 Fueled $\mathrm{Clad}$ Facility System Cell Atmosphere Systems ......... 10

8 Radioisotope Power Systems Facility Floor Plan -10.7-Meters

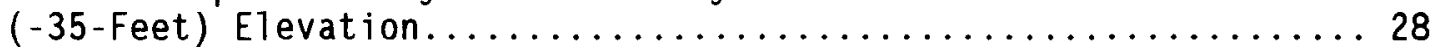

9 Radioisotope Power Systems Facility Floor Plan -5.2-Meters

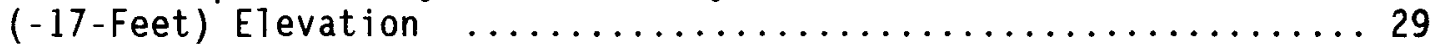

10 General Purpose Heat Source Radioisotope Thermoelectric

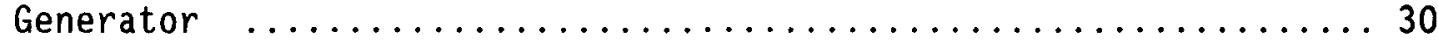

11 Overall Process Flow Diagram for Radioisotope Power Systems

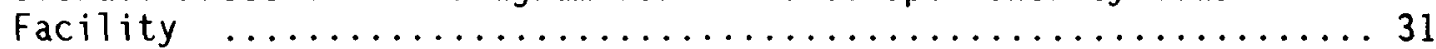

12 Radioisotope Power Systems Facility Cell Atmosphere Systems .... 32

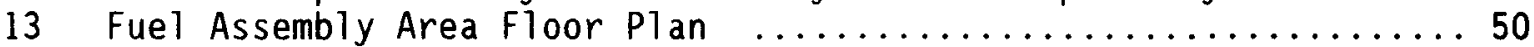

14 Overall Process Flow Diagram for Enriched Uranium Oxide Driver Fuel Fabrication

15 Overall Process Flow Diagram for Neptunium Target Pin Fabrication in the Fuel Assembly Area $\ldots \ldots \ldots \ldots \ldots \ldots \ldots \ldots . \ldots \ldots 2$

16 Fuel Assembly Area Zone I Exhaust Flow Diagram ............ 55 


\section{TABLES}

1-1 Controlled Particle Radionuclide Emission Rates (Actual)

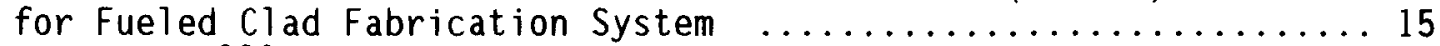

1-2 Input for $220 \mathrm{Rn}$ Emissions Calculations for Fueled Clad

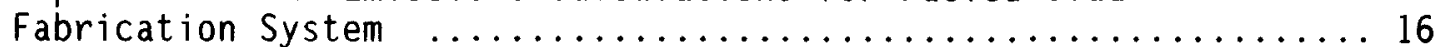

1-3 Controlled Radon Emissions (Actual) for Fueled Clad

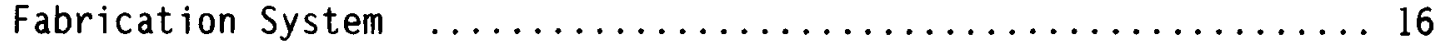

1-4 Controlled Particle Radionuclide Emission Rates (Potential)

for Fueled Clad Fabrication System ...................... 17

1-5 Controlled Radon Emissions (Potential) for Fueled Clad

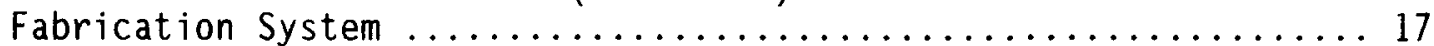

1-6 Fueled Clad Fabrication System Control Technology Survey

Results ........................................ 19

1-7 Offsite Dose Estimates for an Individual Receiving Maximum Exposure to Airborne Radiological Emissions from Fueled Clad

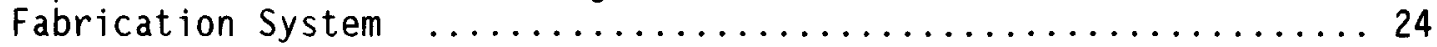

2-1 Controlled Particle Radionuclide Emission Rates (Actual) for Radioisotope Power Systems Facility ...................... 37

2-2 Input for $220 \mathrm{Rn}$ Emissions Calculations for Radioisotope

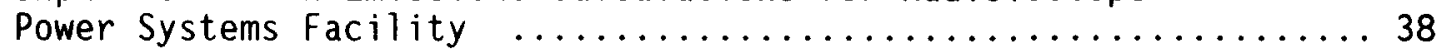

2-3 Controlled Particle Radionuclide Emission Rates (Potential) for Radioisotope Power Systems Facility .................... 39

2-4 Radioisotope Power Systems Facility Control Technology Survey Results ............................ 40

2-5 Controlled Radon Emissions (Potential) for Radioisotope

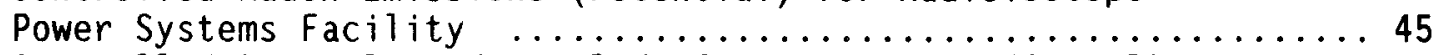

3-1 Controlled Particle Radionuclide Emission Rates (Actual) for Fuel Assembly Area ............................ 59

3-2 Input for $220 \mathrm{Rn}$ Emissions Calculations for Fuel Assembly Area ... 60

3-3 Controlled Particle Radionuclide Emission Rates (Actual)

for Fuel Assembly Area ........................... 60

3-4 Controlled Particle Radionuclide Emission Rates (Potential) for Fuel Assembly Area .............................61

3-5 Controlled Radon Emissions (Potential) for Fuel Assembly Area ... 62

3-6 Fuel Assembly Area Control Technology Survey Results .........63

3-7 Offsite Dose Estimates for an Individual Receiving Maximum Exposure to Airborne Radiological Emissions from Fuel Assembly Area 


\section{PREVENTION OF SIGNIFICANT DETERIORATION NEW SOURCE REVIEW FOR THE FUELED CLAD FABRICATION SYSTEM, THE RADIOISOTOPE POWER SYSTEMS FACILITY, AND THE FUEL ASSEMBLY AREA}

The following "New Source Review" is being submitted by the U.S. Department of Energy-Richland Operations Office (P.0. Box 550, Richland, Washington, 99352), pursuant to WAC 173-403-050 and in compliance with the Department of Ecology "Guide to Processing A Prevention Of Significant Deterioration (PSD) Permit" for three new sources of radionuclide emissions at the Hanford Site in Washington State (Figure 1). The three new sources, the Fueled Clad Fabrication System (FCFS), the Radioisotope Power Systems Facility (RPSF), and the Fuel Assembly Area (FAA), will be located in one facility, the Fuels and Materials Examination Facility (FMEF) of the 400 Area, as shown in Figure 2.

The FMEF was originally designed to provide for post-irradiation examination and fabrication of breeder reactor fuels. These FMEF missions were cancelled before the introduction of any fuel materials or any irradiated material. The current plans are to use the facility to fabricate power supplies for use in space applications and to produce Fast Flux Test Facility (FFTF) fuel and target assemblies. The FCFS and the RPSF will produce materials and assemblies for application in space. The FAA project will produce FFTF fuel and target assemblies.

The FCFS and the RPSF will share the same building, stack, and, in certain cases, the same floor space. Given this relationship, these systems will be dealt with separately to the extent possible. The FAA is a comparatively independent operation though it will share the FMEF complex, as shown in Figure 3 . 


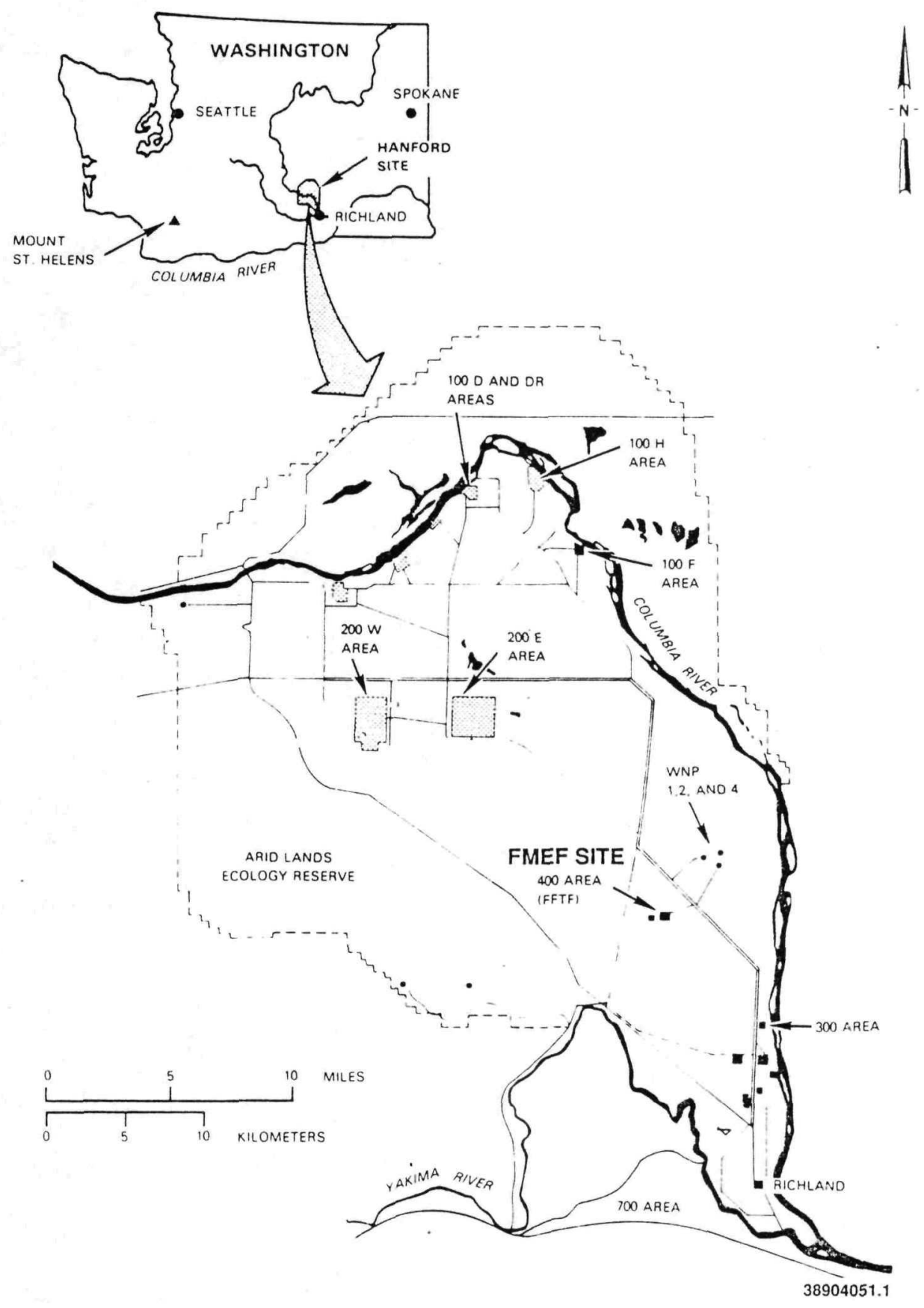

Figure 1. Hanford Site Map. 


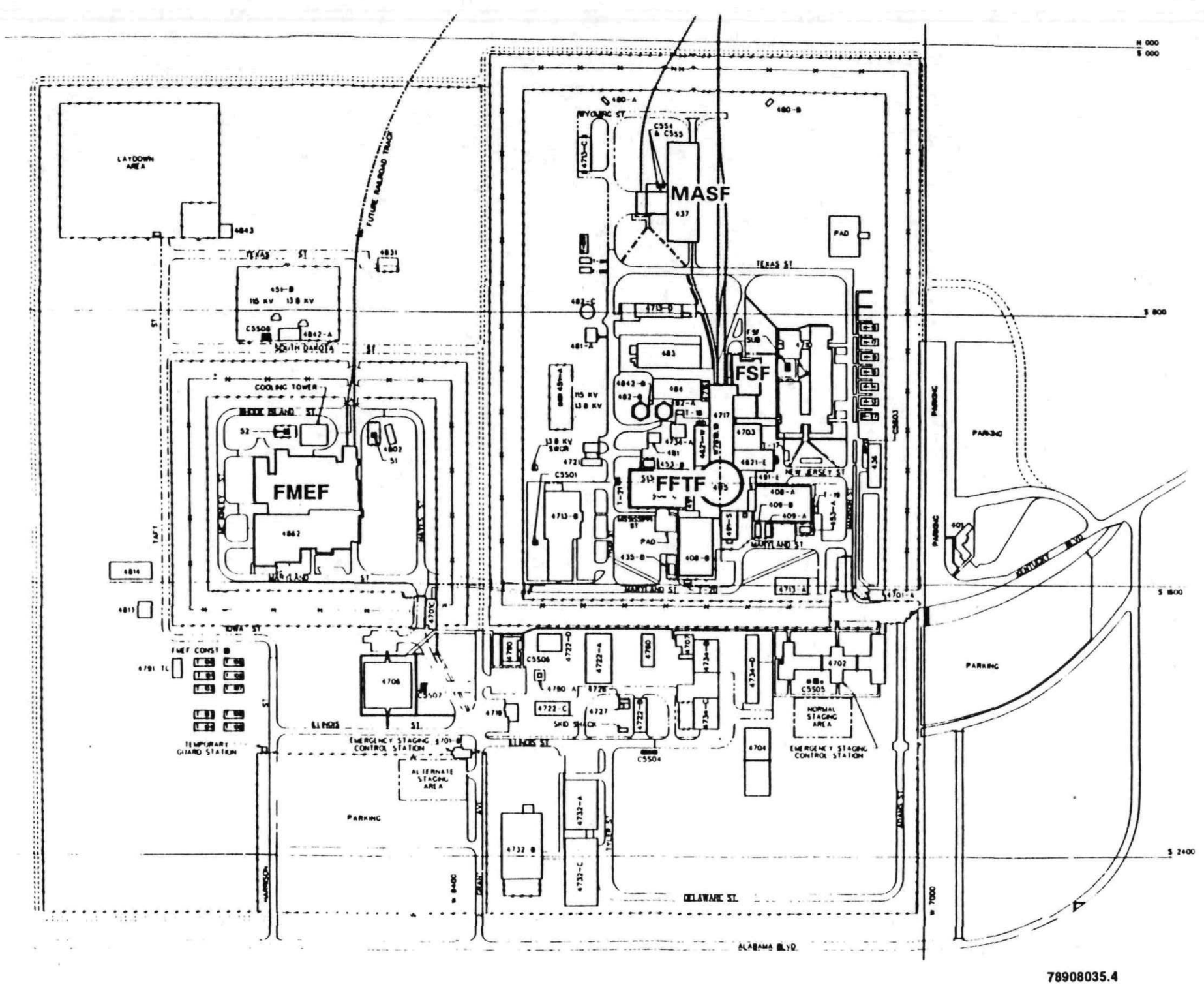

Figure 2. 400 Area Site Layout. 
DOE/RL $89-20$

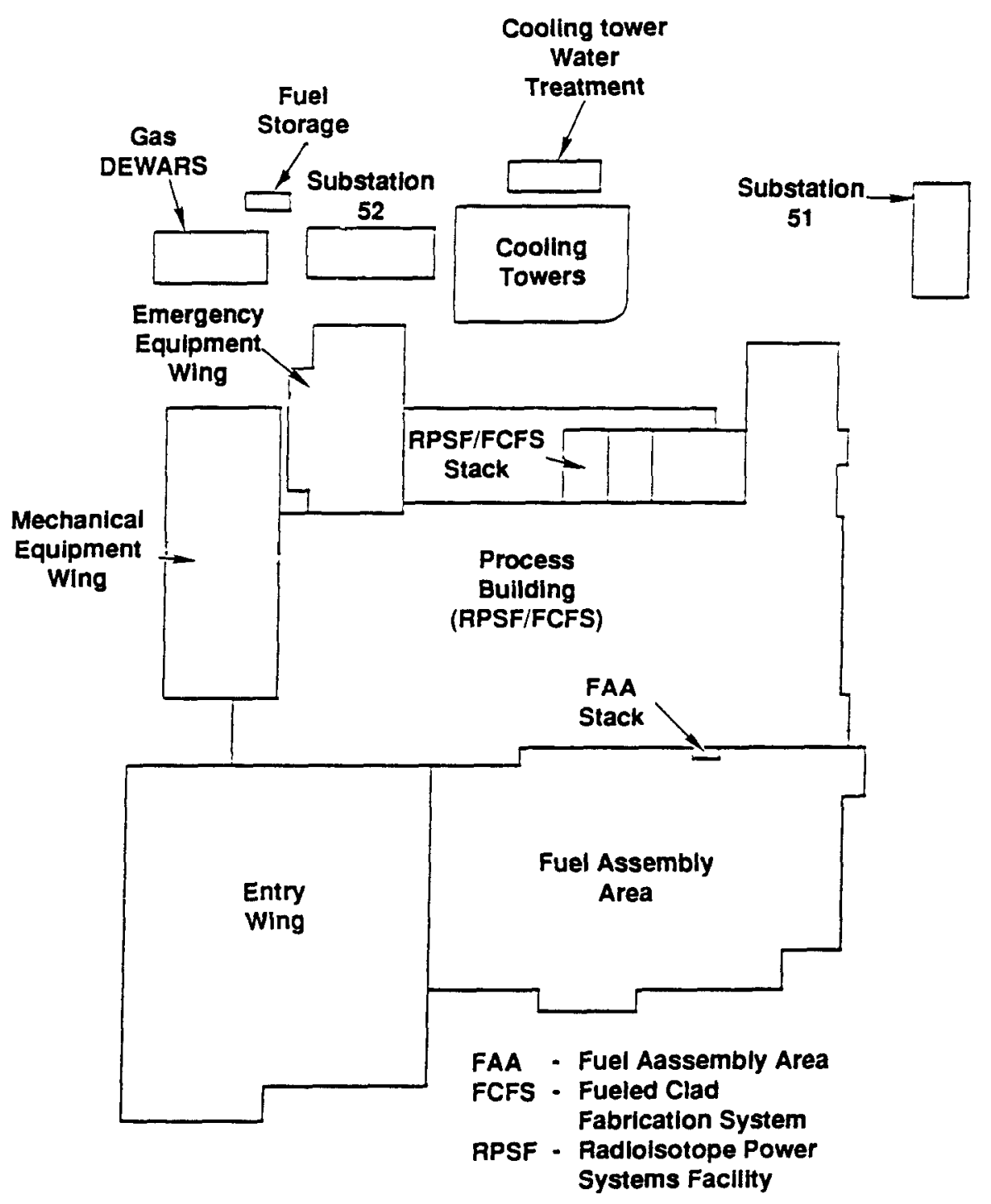

Figure 3. Fuels and Materials Examination Facility. 78908035.9 


\section{Prevention of Significant Deterioration \\ New Source Review for \\ Fueled Clad Facility System}

\subsection{PROJECT LOCATION}

The Fueled Clad Fabrication System (FCFS) will be located in the Fuels and Materials Examination Facility (FMEF) Process Building on the $-10.7-\mathrm{m}$ $(-35-\mathrm{ft})$ level. Figure 4 shows those sections of the FMEF to be used by the FCFS.

\subsection{PROCESS DESCRIPTION}

The FCFS will fabricate $238 \mathrm{PuO}_{2}$ pellets from powder and encapsulate them as fuel clads (FC) for use as heat sources in general purpose heat source (GPHS) modules. Figure 5 shows an FC in a GPHS module. The FCFS will have the capability to perform other plutonium oxide processing and encapsulation operations if needed. It will have a throughput capacity of $200 \mathrm{FCs}$ or approximately $30 \mathrm{~kg}$ (13.6 ib) of encapsulated plutonium dioxide per year. The cells to be used for $238 \mathrm{PuO}_{2}$ pellet encapsulation are shown in Figure 4. An overall process flow diagram is shown in Figure 6.

Plutonium dioxide powder will be received in rooms 524 and 526 , located $12.8 \mathrm{~m}(42 \mathrm{ft})$ abovegrade in the FMEF. A nondestructive assay will be performed on the containers of plutonium dioxide. The containers will then be stored in cel1 132 or 133.

Canisters of powder will be transferred from storage to cell 145 for processing. The canisters will then be cut open and sampled for chemical characterization. The bulk of the powder will be loaded into furnace boats and $\mathrm{placed}$ in a furnace. In the furnace, ${ }^{16} \mathrm{O}_{2}$ will replace ${ }^{17} \mathrm{O}_{2}$ and ${ }^{18} \mathrm{O}_{2}$ in the $238 \mathrm{PuO}_{2}$ powder. This process results in a significant reduction of the neutron emission rate, which is necessary for the use of the $238 \mathrm{PuO}_{2}$ in power sources. After oxygen exchange, the $238 \mathrm{PuO}_{2}$ powder will be bal1 milled, sieved, cold pressed, and granulated. The granules will be sintered into shards in an atmosphere containing oxygen, atomic weight 1b. Sixty percent of the granules will be sintered at $1100^{\circ} \mathrm{C}\left(2012^{\circ} \mathrm{F}\right)$, and $40 \%$ at $1600^{\circ} \mathrm{C}$ $\left(2912^{\circ} \mathrm{F}\right)$. After sintering, the shards will be sieved to separate the agglomerated shards and recombined in a ball mill dedicated to shard blending.

The resulting granules will be transferred from cell 145 to the hot pressing glovebox in room 141. The hot pressing ensures good control of pellet dimensions and microstructure. After hot pressing, the pellets will be transferred to cell 144 where they will be sintered in a dedicated production furnace at $1525^{\circ} \mathrm{C}\left(2777^{\circ} \mathrm{F}\right)$, in an atmosphere containing oxygen, atomic weight 16 . The pellets will then be vacuum heat-treated in a sintering furnace at $1500^{\circ} \mathrm{C}\left(2732^{\circ} \mathrm{F}\right)$. The principal reason for the final 


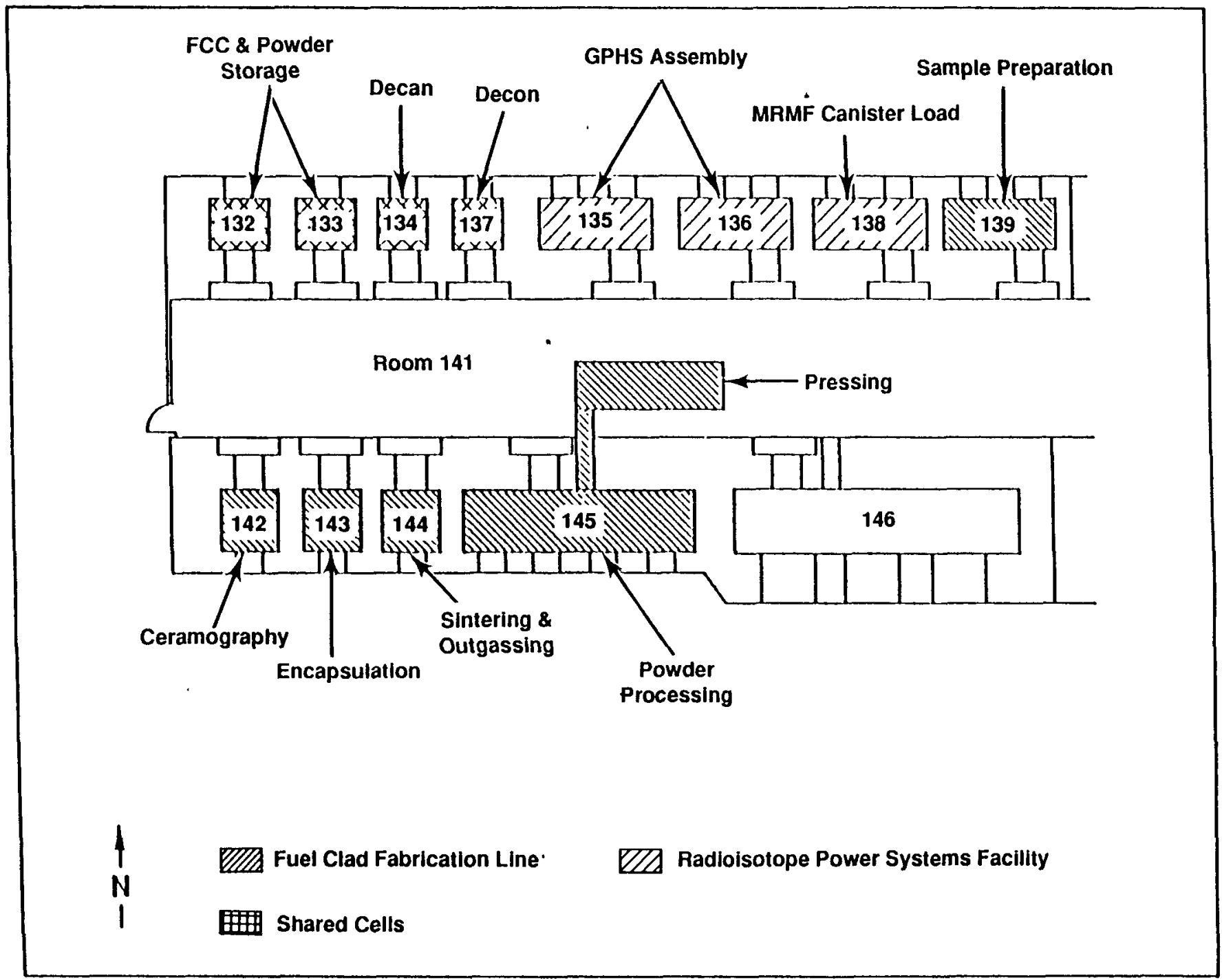

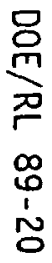

Figure 4. FMEF Hot Cells Located 10.7 Meters

(35 Feet) Belowgrade in the Process Building. 


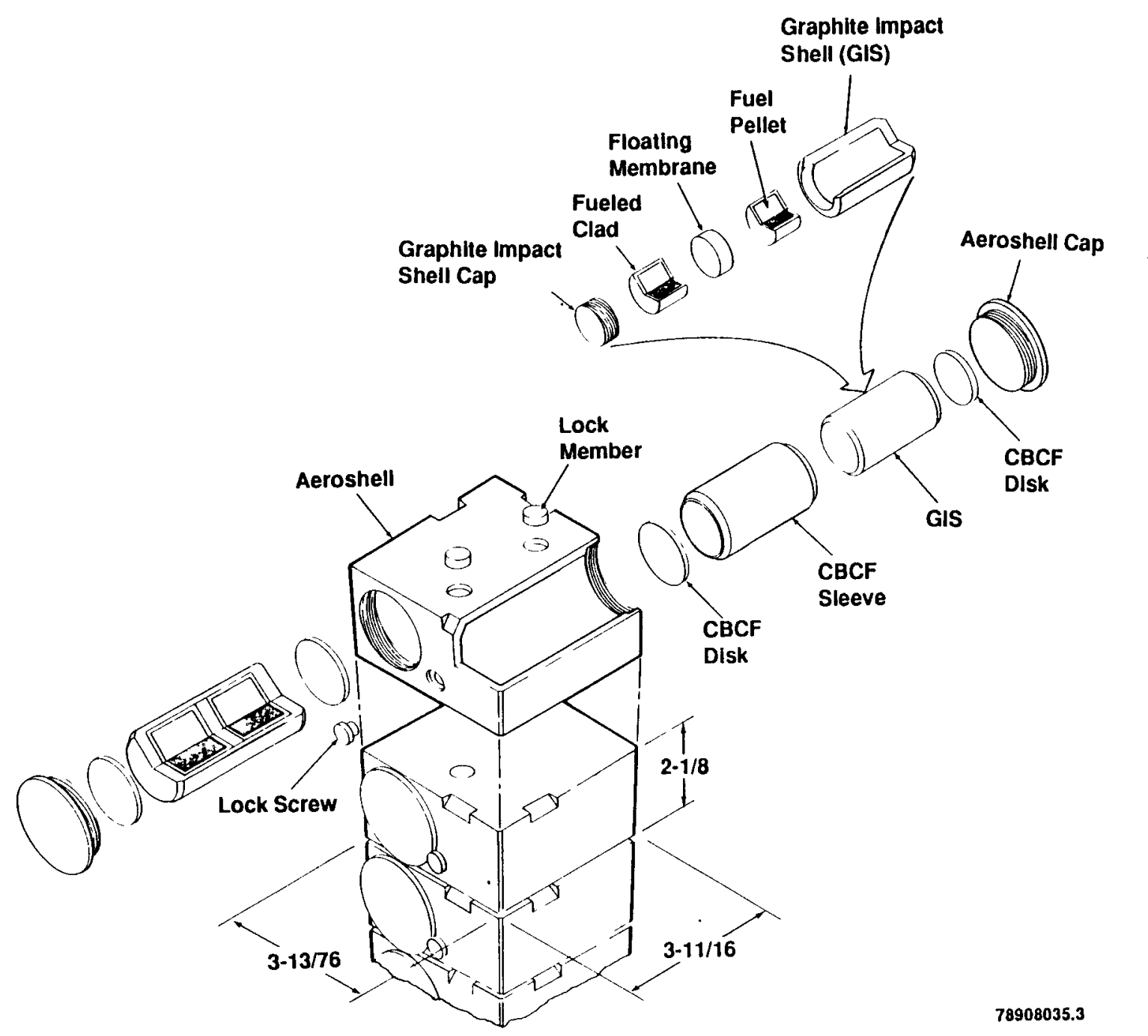

Figure 5. General Purpose Heat Source Module Assembly. 

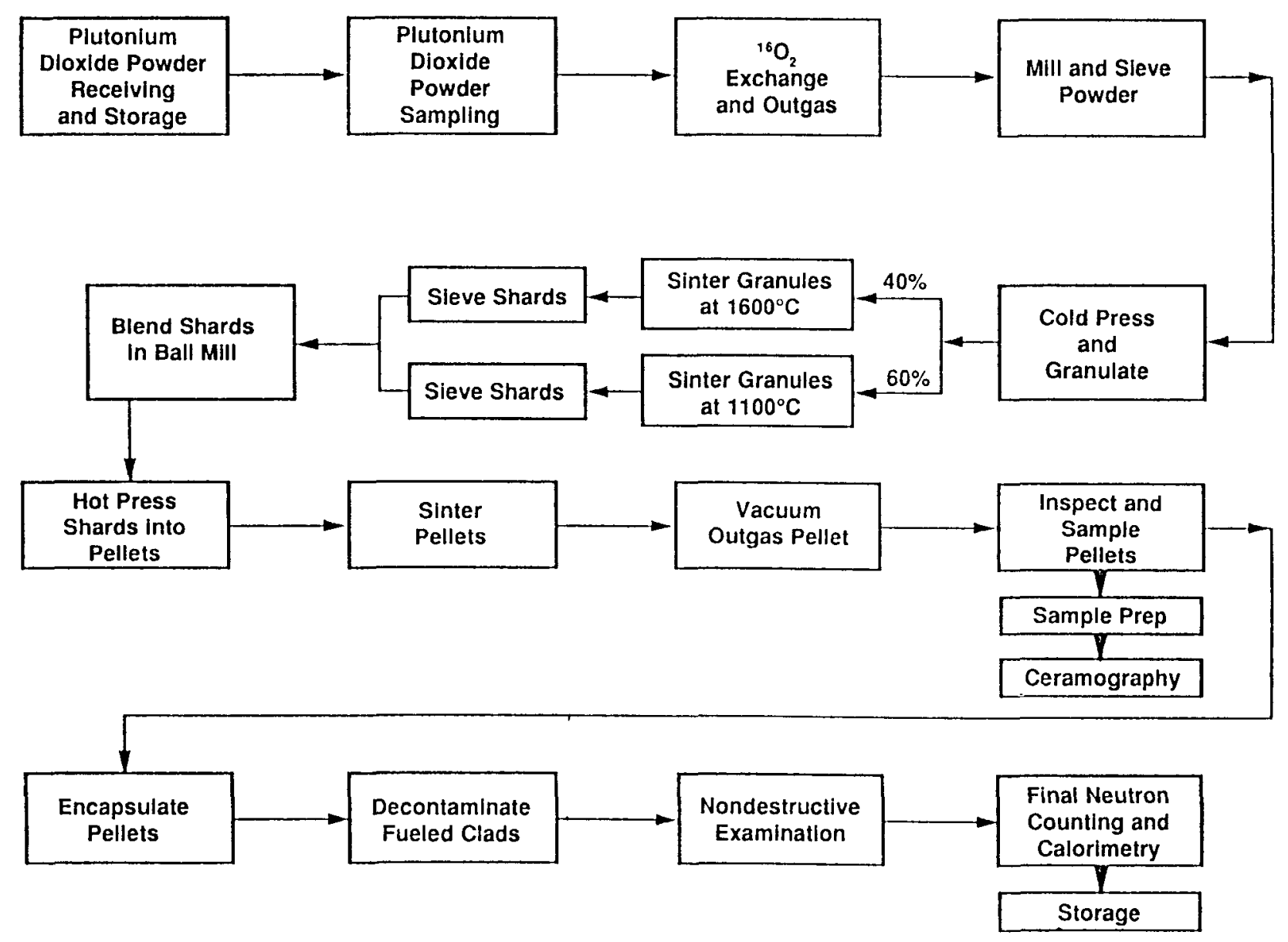

Figure 6. Overall Process Flow Diagram for the Fueled Clad Facility System. 
sintering and outgassing operations is to ensure that the fuel pellet will remain dimensionally stable at expected operating temperatures. The sintering operation also burns off carbon introduced onto the pellet in the hot pressing operation and restores stoichiometry of the pellets to $238 \mathrm{PuO}_{2}$. The outgassing operation further removes volatile impurities such as helium. After heat treatment, the fuel pellets will be sampled. The samples will be prepared in cell 139 by grinding, polishing, mounting, and etching. After sample preparation, the pellets will be characterized by ceramography in cel1 142 .

The remaining pellets will be transferred to cell 143 after the heat treatment operation. In cell 143, pellets will be loaded into iridium capsules and the capsules will be welded shut in a helium atmosphere. The FCs will then be transferred to cell 137 for decontamination and nondestructive examination. Nondestructive examination will include ultrasonic testing of the capsule welds and helium leak checks.

\subsection{SOURCES OF EMISSIONS}

The FCFS will be provided with ventilation Zones I, II, and III, and airlocks as required for zone separation in high-traffic access areas. Areas denoted Zone I will contain the radioactive materials being processed and will be separated from surrounding ventilation Zone II areas. Ventilation Zone III areas will be those support areas that bound ventilation Zone II. There will be a negative pressure gradient from Zone III to I so that any contaminants will flow into Zone I and through the facility emissions abatement systems. Al1 Zone I air flows out the FMEF (RPSF/FCFS shared) stack.

Releases of radioactive materials to the ventilation system will occur in Zone I and may occur in Zone II. Releases of radioactive materials to the ventilation system from Zone III are unlikely. The process activities previously described in Section 2.0 will take place in these zones. Figure 7 depicts FCFS cell atmosphere flow and indicates points of emission to the environment.

\section{Zone I}

Cells 132, 133, 137, 139, 142, 143, 144, 145, and the glovebox in room 141 will be part of the Zone I ventilation system. With the exception of cells 132 and 133 , these cells will be used in the processing of the plutonium dioxide powder into pellets and in the encapsulation of these pellets. Cells 132 and 133 will be used to store the plutonium dioxide powder. Because the plutonium dioxide powder will be contained in a canister, the potential for releases of radioactive materials to the ventilation system is small. The relative contributions of the processing steps to the radioactive releases are discussed below.

Cell 145 will be used for powder processing. Powder processing includes opening the canisters containing the powder, sampling the powder, transferring powder into furnace boats, performing the ${ }^{16} 0_{2}$ exchange, 


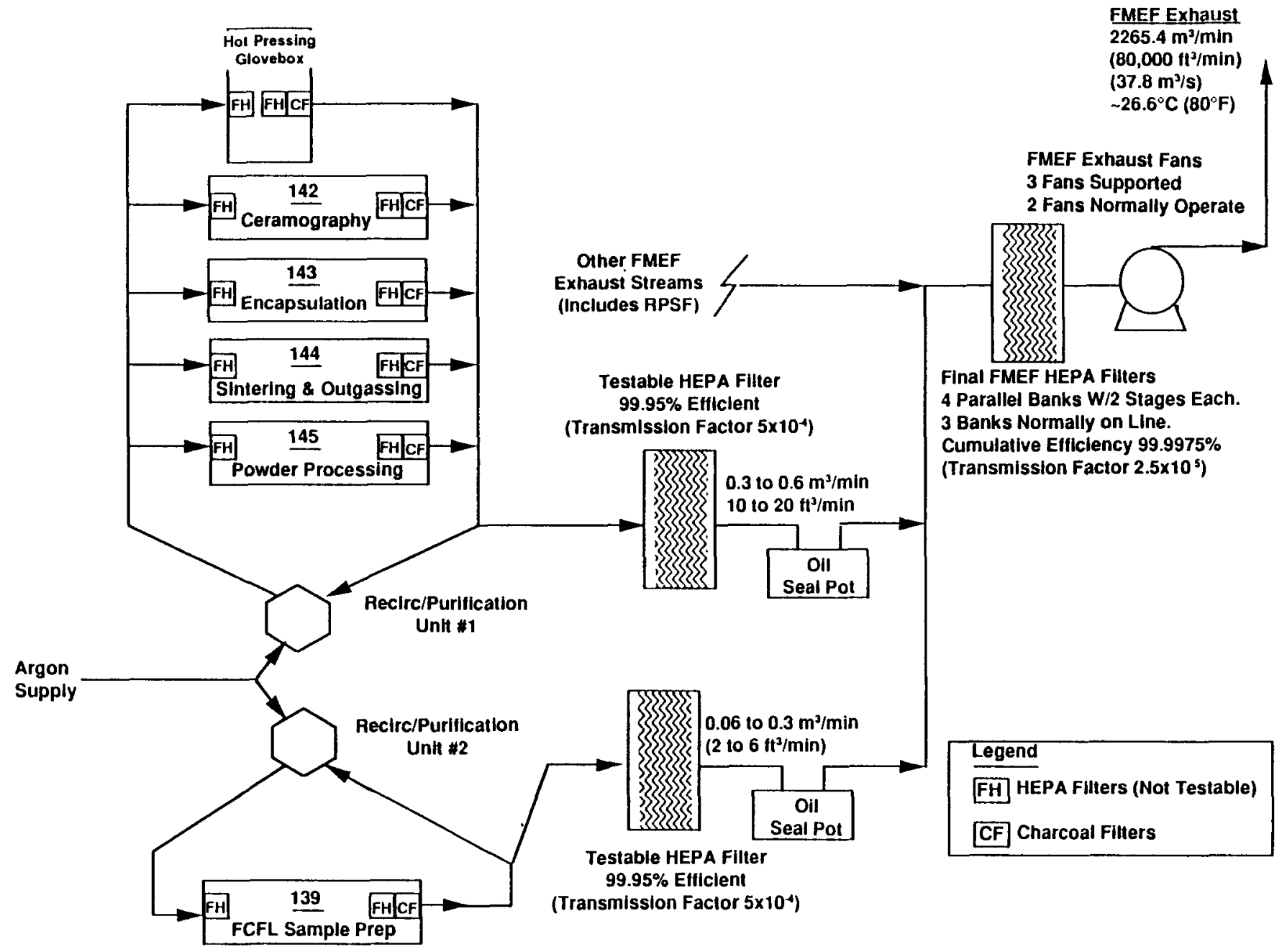

Figure 7. Fueled Clad Facility System Cell Atmosphere Systems. 
ball milling the powder, sieving the powder, cold pressing the powder, sintering the granules, sieving the shards, and ball milling the shards. These operations will produce the majority of the particulate radioactive materials that reach the ventilation system. Gaseous emissions from the ${ }^{16} \mathrm{O}_{2}$ furnace and the sintering furnace are not expected since plutonium dioxide is not volatile.

The glovebox in room 141 will be used for hot pressing the shards into pellets. Cell 144 will be used for sintering and vacuum heat treating the pellets. Powder will not be handled in cell 144 enclosures, nor will there be any operations (such as grinding) performed, which may result in the production of particulate matter. However, because the plutonium dioxide is not yet encapsulated, the release of particulate radioactive materials to the ventilation system is expected to be relatively moderate in comparison to other operations. Gaseous emissions from hot pressing and from the sintering and vacuum heat treating furnaces are not expected, because plutonium dioxide is not volatile.

Cell 139 will be used to prepare sample pellets for ceramography in cell 142. Sample preparation will include grinding, polishing, mounting, and etching. Grinding and polishing operations have the potential for the production of particulate matter; therefore, releases of particulate matter from cell 139 are expected. The potential for releases of radioactive materials during sample characterization by ceramography in cell 142 will be small.

In cell 143, pellets will be loaded into iridium cladding and the cladding will be welded shut. In cell 137, the FCs will be decontaminated. During pellet loading and decontamination, surface particulate contamination may become suspended. Releases are not expected to be nearly as great as during powder handling operations; therefore, the release of particulate radioactive materials to the ventilation system from these cells is expected to be small.

Following decontamination, nondestructive examination of $F C s$ will also be performed in cell 137. Because the plutonium dioxide pellets will be encapsulated in a cladding that has been decontaminated, the potential for releases of radioactive materials is small.

Zone II

Rooms 126, 127, 174, 149, 153, 148, 141, 152, and operating corridors 131,123 , and $125 \mathrm{~W}$ will be part of the Zone II ventilation system. Releases of radioactive materials to the Zone II ventilation system are not likely to occur because processing of radioactive materials will not occur in the Zone II rooms; the negative pressure gradient from Zone II to Zone I would carry any release to the Zone I ventilation system; and there are backdraft dampers acting as check-valves between Zone II and Zone III. 


\section{Zone III}

Zone III includes those areas surrounding the Zone II ventilation area. Releases of radioactive materials to the Zone III ventilation system are highly unlikely because of the negative pressure gradient between Zone III and Zone II and because radioactive materials will not be handled in the Zone III room.

\subsection{DESIGN AND OPERATING PARAMETERS}

\subsection{HOURS OF OPERATION}

The FCFS is intended to operate $8 \mathrm{~h} / \mathrm{d}, 5 \mathrm{~d} / \mathrm{wk}, 52 \mathrm{wk} / \mathrm{yr}$ (including maintenance downtime).

\subsection{NORMAL AND MAXIMUM PRODUCTION RATES}

Production rates are stated in terms of FCs. The normal production rate is $200 \mathrm{FC} / \mathrm{yr}$. The theoretical "maximum" production rate for $8 \mathrm{~h} / \mathrm{d}$, $5 \mathrm{~d} / \mathrm{wk}, 52 \mathrm{wk} / \mathrm{yr}$, is $307 \mathrm{FC} / \mathrm{yr}$. (The maximum production rate was developed assuming no need to shut down any plant process equipment for maintenance or any other reason for a period of one yr.)

\subsection{FUEL REQUIREMENTS}

The fuel used by FMEF and its enclosed activities, including FCFS, is electricity. The base load for FMEF and its utilities is estimated to be $10 \times 10^{6} \mathrm{~kW} / \mathrm{h}$ annually. The incremental load for FCFS is estimated to be $2.9 \times 10^{6} \mathrm{~kW} / \mathrm{h}$ annually.

\subsection{RAW MATERIAL REQUIREMENTS}

At a normal production rate of $200 \mathrm{FC} / \mathrm{yr}$, FCFS will use the following materials annually:

$0238 \mathrm{PuO}_{2}$ powder: $30 \mathrm{~kg}(66.1 \mathrm{lb})$

0 Iridium metal sheathing: $10 \mathrm{~kg}(22.0 \mathrm{lb})$ : used to sheath fuel pellets

- Iridium metal foil: $126 \mathrm{~g}(7.6 \mathrm{oz})$ : used during closure welding to shield the fuel pellet

0 Nitric acid: between 37.8 and $56.8 \mathrm{~L}(10$ and 15 gal): decontamination agent 
0 Deionized water: between 37.8 and $56.8 \mathrm{~L}$ (10 and 15 gal)

decontamination agent

o Aqua-Regia: less than 18.9 L (5 gal) used for weld etching.

\subsection{EMISSIONS CONTROL SYSTEM}

Because the radioactive airborne emissions from FCFS will consist primarily of particulate matter generated during the processing of the $238 \mathrm{PuO}_{2}$ powder (Section 2.1), the emissions control system must be capable of containing micrometer-and submicrometer-size particles.

As discussed in Section 2.1, the FCFS operations are provided with ventilation zones I, II, and III, with a negative pressure gradient from Zone III to Zone I, to provide maximum confinement of radioactive contamination. Zone I gloveboxes will be operated at $-0.50 \pm 0.25$ in. WG pressure relative to Zone II atmosphere. Zone I cells, with manipulators, will be operated at $-0.85 \pm 0.15 \mathrm{in}$. WG pressure relative to Zone II atmosphere. Zone II will be operated at greater than -0.10 in. \pm 0.05 in WG pressure relative to Zone III. Zone III will be operated at greater than -0.10 in. WG pressure relative to Zone IV (outside atmosphere).

Zone I ventilation areas in which the radioactive materials are processed use a recirculated argon atmosphere. Special sealed structures and structural penetrations are implemented to separate Zone I and Zone II areas. Zone I and Zone II exhausts are vented to separate primary high-efficiency particulate air (HEPA) filtration steps before being combined and routed to final filtration, consisting of three banks of HEPA filters, and subsequently discharged to the atmosphere. Zone III exhaust is ultimately routed along with other plant exhausts to the final filtration step and discharged to the atmosphere.

Provision of both primary and final particulate control measures, as described above, allows for high-efficiency removal of particulates and provides system redundancy in the event of a possible failure of one of the emission control units. In addition, the FCFS Zone I cells are equipped with non-testable HEPA filters on both the inlet and outlet flows to minimize the radionuclide contamination of the connected atmosphere control systems.

Final high-efficiency particulate filtration before discharge of the radionuclide contaminated gases to the atmosphere is a nuclear industry standard. Generally, two-stage filtration is use for this purpose.

Presently employed final filtration techniques in the nuclear industry include combination prefilter and HEPAs, deep-bed glass-fiber filters, and deep-bed sand filters. The best available radionuclide control technology (BARCT) assessment developed for this proposed project demonstrated that the prefilter and HEPA system provides the highest degree of removal efficiency (see Section 6.0). 


\subsection{EMISSIONS - TYPE AND QUANTITY}

\subsection{REPRESENTATIVE EMISSIONS FROM THE EXISTING SOURCE}

The FMEF was designed and constructed to produce production and test-fuel assemblies for the Liquid Metal Reactor program and provide a capability for examining fuels and materials following irradiation. These FMEF missions were cancelled before introducing fuel material or other irradiated material into the facility.

The only "emissions" from the FMEF stack have been from the heating, ventilation, and air conditioning (HVAC) system functioning to heat or cool the facility. The average temperature at the stack is $26.6^{\circ} \mathrm{C}\left(80^{\circ} \mathrm{F}\right.$.) The average stack flow rate is $2,265 \mathrm{~m}^{3} / \mathrm{min}\left(80,000 \mathrm{ft}^{3} / \mathrm{min}\right)$.

\subsection{PROJECTED ACTUAL CONTROLLED EMISSIONS}

The projected actual controlled emission rates of particulate radionuclides for the FCFS were calculated based on an annual $238 \mathrm{PuO}_{2}$ throughput of $30 \mathrm{~kg}(66.1 \mathrm{lb})$ and using a release adjustment factor (RAF) of $2.5 \times 10^{-10}$.

The RAF assumes that $1 \%$ (the release factor) of the throughput material will become entrained in the cell atmosphere and pass through the ventilation system. (This is an extremely conservative assumption because there are non-testable HEPA filters between the hot cells, gloveboxes, hoods, and enclosures and the ventilation system. The HEPAs are $99.97 \%$ efficient on installation. Therefore, for $1 \%$ of the entire throughput to become entrained in the ventilation system, over $100 \%$ of the entire throughput would have to be released.) The ventilation system is assumed to contain three HEPA filters in series, which is equivalent to a transmission factor of $2.5 \times 10^{-8}$. (It is understood that aggregate recoil particles from a source of alpha activity appear to penetrate HEPA filters much more effectively than would be expected on the basis of filter efficiency for similar sized stable aerosols. It is al so understood [McDowell et al. 1976] that where the aerosols are realistic in terms of what comes out of the facility, the recoil effect is not proven. In light of the possibility of the recoil effect, monitoring, appropriate filter changeouts, and other administrative controls will be implemented to ensure filter system integrity.) (As noted above, the hot cells, gloveboxes, hoods, and enclosures actually have an additional HEPA filter; however, this filter is not testable and the removal efficiency cannot be verified during operation. Therefore, no credit is taken for these filters in the dose calculations.) The RAF is the product of the release factor and the transmission factor. The projected actual controlled radioactive airborne particulate emissions releases for the FCFS are shown in Table 1-1. 
$\mathrm{DOE} / \mathrm{RL} 89-20$

Table 1-1. Controlled Particle Radionuclide Emission Rates (actual) for Fueled $\mathrm{Clad}$ Fabrication System ( $\mathrm{C} / \mathrm{yr}$ ) (Emissions at Stack).

Nuclide

$$
\begin{aligned}
& 236 \mathrm{Pu} \\
& 238 \mathrm{Pu} \\
& 239 \mathrm{Pu} \\
& 240 \mathrm{Pu} \\
& 241 \mathrm{Pu} \\
& 242 \mathrm{Pu}
\end{aligned}
$$

\section{Emission rate}

$2.79 \mathrm{E}-08$

$9.95 \mathrm{E}-05$

$3.14 \mathrm{E}-08$

$1.49 \mathrm{E}-08$

$1.15 \mathrm{E}-05$

$4.39 E-10$

The controlled emission rates of gaseous radionuclides $(220 \mathrm{Rn})$ for the FCFS were calculated conservatively from the total amount being generated within the fuel material being handled. (In reality, a large fraction of the $220 \mathrm{Rn}$ will decay before it leaves the fuel because ${ }^{220} \mathrm{Rn}$ has a half-life of only $55.6 \mathrm{~s})$ Because the vent rate from the cells is controlled at the lowest flow rate possible to protect the comparatively expensive argon environment, $220 \mathrm{Rn}$ is held up with the argon. The emission rate of $220 \mathrm{Rn}$, therefore, is equal to the initial $220 \mathrm{Rn}$ activity reduced by the factor 0.0032 to take into account decay during holdup. The factor 0.0032 is developed as follows:

The amounts of radon shown as released take into consideration the holdup in the argon filled cells before release to the exhaust system. These cells have a combined volume of about $5000 \mathrm{ft}^{3}$, with a combined total exhaust flow rate of $\mathrm{ft}^{3} / \mathrm{min}$. The ventilation removal rate is then $L V=\left(12 \mathrm{ft}^{3} / \mathrm{min}\right) /\left(5000 \mathrm{ft}^{3}\right)=0.0024 / \mathrm{min}$. Including the decay of the $220 \mathrm{Rn}$ gives a resultant factor of $0.0032=L v /[L(220)+L v]$ to correct for decay during holdup in the argon cells.

A small correction was also applied for decay in transit through the ventilation system. The duct diameter was assumed to be 3 in., giving a linear flow rate of $4.1 \mathrm{ft} / \mathrm{s}$ down the duct. The distance travelled to the main exhaust duct was assumed to be $10 \mathrm{ft}$, so that 0.97 was the decay correction. The number for $220 \mathrm{Rn}$ in Table 1-3 includes both the holdup and the decay factors.

The amount, then, of $220 \mathrm{Rn}$ released from the facility depends upon the initial radon activity (which is determined by the $236 \mathrm{Pu}$ impurity concentration, the preprocessing decay time of $236 \mathrm{Pu}$, and the residence time of $220 \mathrm{Rn}$ inside the facility before being emitted) multiplied by the above described decay factors. The specific maximum release rate data for these factors and that resulting rate are listed in Tables 1-2 and 1-3. 
Table 1-2. Input for 220 Rn Emissions Calculations for Fueled Clad Fabrication System.
Facility Pu Inventory:
Initial $238 \mathrm{Pu}$ purity:
$30.0 \mathrm{~kg}(66.1 \mathrm{lb}) \mathrm{Pu}$
Pre-processing decay time:
$10.0 \mathrm{p} / \mathrm{M}$
Facility residence time:
0.25 months
52.0 weeks

Table 1-3. Controlled Radon Emission Rates (Actual) for Fueled Clad Fabrication System ( $\mathrm{C} / \mathrm{yr}$ ) (Emissions at Stack).

$\frac{\text { Nuclide }}{220 \mathrm{Rn}} \quad \frac{\mathrm{Ci} / \mathrm{yr}}{99}$

\subsection{PROJECTED POTENTIAL CONTROLLED EMISSIONS}

Projected potential controlled emission rates are the emission rates that would result from operation of the facility at maximum capacity $24 \mathrm{~h} / \mathrm{d}, 365$ $\mathrm{d} / \mathrm{yr}$. The projected potential controlled emission rates for the FCFS have been calculated based on the data developed in sections $3.1,3.2$, and 4.2. To perform these calculations, the assumption was made that a linear relationship exists between the amount of throughput and the amount of emissions.

The projected potential controlled emission rate has been calculated from the controlled radionuclide emission rates 1 isted in Tables 1-1 and 1-3 using the following formula:

$(8,760 / 2,080)(307 / 200)($ controlled radionuclide emission rate $)=$ projected potential controlled emission rate.

The factor $8,760 / 2,080$ in the above equation adjusts the controlled particle radionuclide emission rates to $24 \mathrm{~h} / \mathrm{d}$ and $7 \mathrm{~d} / \mathrm{wk}$ operation. The controlled radionuclide emission rates are based on operation of the facility $8 \mathrm{~h} / \mathrm{d}$ and $5 \mathrm{~d} / \mathrm{wk}$ for $1 \mathrm{yr}$ (2,080 $\mathrm{hr}$ of operation). Operation of the facility $24 \mathrm{~h} / \mathrm{d}$ and $7 \mathrm{~d} / \mathrm{wk}$ for $1 \mathrm{yr}$ would result in $8,760 \mathrm{~h}$ of operation.

The factor $307 / 200$ in the above equation adjusts the production rate to maximum efficiency. The controlled radionuclide emission rates are based on a production rate of $200 \mathrm{FC} / \mathrm{yr}$. The $200 \mathrm{FC} / \mathrm{yr}$ production rate would result from plant operations at expected efficiency, $8 \mathrm{~h} / \mathrm{d}$ and $5 \mathrm{~d} / \mathrm{wk}$. Operations at 100\% efficiency, $8 \mathrm{~h} / \mathrm{d}$ and $5 \mathrm{~d} / \mathrm{wk}$ would result in a production rate of $307 \mathrm{FC} / \mathrm{yr}$. 
The projected potential controlled particulate radionuclide emission rates for the FCFS are listed in Table 1-4. The potential controlled gaseous radionuclide emission rate for the FCFS is stated in Table 1-5.

Table 1-4. Controlled Particle Radionuclide Emission Rate (Potential) for Fueled $\mathrm{Clad}$ Fabrication System ( $\mathrm{C} / \mathrm{yr}$ ) (Emission at Stack).

Nuclide

$$
\begin{aligned}
& 236 \mathrm{Pu} \\
& 238 \mathrm{Pu} \\
& 239 \mathrm{Pu} \\
& 240 \mathrm{Pu} \\
& 241 \mathrm{Pu} \\
& 242 \mathrm{Pu}
\end{aligned}
$$

Emission rate

$1.80 \mathrm{E}-07$

$6.43 \mathrm{E}-04$

$2.03 E-07$

$9.63 \mathrm{E}-08$

7.43 E- 05

$1.19 \mathrm{E}-08$

Table 1-5. Controlled Radon Emission Rates (Potential) for Fueled $\mathrm{Clad}$ Fabrication System ( $\mathrm{C} / \mathrm{yr}$ ) (Emission at Stack)

$$
\begin{array}{ll}
\text { Nuclide } & \frac{\mathrm{Ci} / \mathrm{yr}}{620 \mathrm{Rn}}
\end{array}
$$

\subsection{ANTICIPATED CONSTRUCTION SCHEDULE}

The following construction schedule is projected:

Start of design (conceptual)

Completion of design (definitive)

Start of major equipment procurement

Completion of major equipment procurement

Start of construction (pre-construction activities)

Completion of construction
October 1988

April 1990

November 1989

April 1991

October 1989

May 1991

\subsection{A DEMONSTRATION OF BEST AVAILABLE CONTROL TECHNOLOGY (BACT) SELECTION}

Radionuclides are the only regulated pollutants of concern projected to be emitted by the proposed source in significant quantities, as defined by Prevention of Significant Deterioration (PSD) regulations. Therefore, the demonstration of $B A C T$ has been 1 imited to impacts of ambient radionuclide concentrations, or a demonstration of BARCT. 
A BARCT is defined by WAC $-402-80-40$ as follows:

Technology which will result in a radionuclide emission limitation based on the maximum degree of reduction for radionuclides which would be emitted from any proposed stationary source or modification of a source which the permitting authority on a case-by-case basis, taking into account energy, environmental, and economic impacts and other costs, determines is achievable for such source or modification through application of production processes or available methods, systems, and techniques. In no event shall application of best available radionuclide technology result in emissions of radionuclides which would exceed the ambient annual standard limitation specified in this chapter.

The selection of the emissions control system described in Section 3.5 is supported as BARCT for the pollutants to be emitted by the FCFS by the following.

\section{Control Alternatives}

Radionuclide emissions from the FCFS are limited to particulate matter generated during the processing of $238 \mathrm{PuO}_{2}$ powder. Based on the handling operations that will be performed and the physical characteristics of the powder, suspended particulate matter is anticipated to be in the micrometerand submicrometer-size range.

In order to identify all possible emission controls for this process, a nuclear and cross-industry survey for high-efficiency particulate matter controls was conducted (Appendix A). Therefore, devices capable of collecting only large-diameter particles are not included in the survey. All of the controls identified have been previously applied in radiochemical processing operations. High-efficiency particulate controls in the industrial sector are limited to HEPA filters, used for cleanroom applications and packed fiber filters, for high-quality product gas filtration (essentially, high-efficiency mist eliminators [HEME]). Potential control devices identified in the surveys are presented in Table 1-6. Detailed process descriptions and evaluations are presented in Appendix B.

of the potential particulate controls identified in Table $1-6$, only the prefilter and HEPA can be applied to primary particulate control in this application. 
Table 1-6. Fueled Clad Fabrication System Control Technology Survey Results.

\section{Particulate Matter}

HEPA filter

Deep-bed sand filter

Deep-bed glass-fiber filter

High-efficiency mist eliminator

Prefilter
$99.97 \%$ for $0.3-\mu \mathrm{m}$ particles $99.95 \%$ for $0.3-\mu \mathrm{m}$ particles 99. $9 \%$ for $0.3-\mu \mathrm{m}$ particles $99.5 \%$ for $1-\mu \mathrm{m}$ particles $85 \%(\max )$ for $0.3-\mu \mathrm{m}$ particles

In the nuclear industry, prefilters are generally used in combination with HEPAs to remove the larger particles in the exhaust stream, thus increasing the service life of the HEPAs. Extremely large units, such as the deep-bed sand and deep-bed fiber filters cannot be considered as primary filters because adequate floor space is not available. Although the HEME is relatively small (about $0.9 \mathrm{~m}[3 \mathrm{ft}]$ in length), it is significantly less effective than the HEPA in its removal of small particles, it requires additional plumbing (for possible filter cleaning with a water-wash), and it is normally not used for dry room offgas systems. Therefore, a combination prefilter/HEPA assembly is considered the only applicable particulate control alternative based on performance and operating/physical constraints for primary FCFS exhaust treatment and is thus proposed as BARCT for this particular application. No further analysis of energy, environmental, or economic impacts is required because the control technology identified has been determined to be the technology that is both appropriate and allows the lowest emission rate of radionuclides. Any other control technology would not provide a comparable low environmental impact, regardless of energy or economic impact. The BARCT analysis will, therefore, be limited to the final filtration processes only.

After primary treatment, all the exhaust from the FCFS operations is combined and routed to a final filtration step before discharge through the main building stack. Final high-efficiency particle filtration before discharge of radionculide-contaminated gases to the atmosphere is a nuclear industry standard. Generally, two-stage filtration is used for this purpose. Presently employed final filtration techniques in the nuclear industry include combination prefilter and HEPAs, deep-bed glass-fiber filters, and deep-bed sand filters (Table 1-6). Deep-bed glass-fiber and sand filters are normally installed upstream of a final contact HEPA filter. Therefore, the alternative control systems for the final FCFS exhaust that will be evaluated include the following: 
Alternative 1 - deep-bed glass-fiber filter/one-stage HEPA

Alternative 2 - deep-bed sand filter/one-stage HEPA

Alternative 3 - two-stage HEPA

The following will present an evaluation of these final emission control a)ternatives based on environmental, energy, and economic impacts to demonstrate BARCT for the FCFS emissions.

\section{Environmental}

All of the three alternatives incorporate a HEPA filter as the secondstage control device. Studies have shown that the removal efficiency of a HEPA placed downstream of another high-efficiency particulate control device (such as a deep-bed sand filter or another HEPA) is lower than that of a single-stage HEPA (Zippler 1974). It is postulated that this is because of the extraction of the more readily collected particles in the initial filter (Moore and Fullam 1984). Sufficient data are not available to determine the effect that this would have on the overall removal efficiency of each alternative control system. For the purposes of this analysis, it is assumed that the second-stage HEPA performs identically for each system. Therefore, the overall efficiency is directly related to the removal efficiency of the first-stage unit. As shown in Table 1-6, alternative 3 (two-stage HEPA) would provide a somewhat higher performance than alternatives 2 and 1 . Because ground-level radionuclide impacts are directly dependent on emission rate (and thus removal efficiency), the implementation of alternative 3 would result in the lowest air quality impact.

All three alternatives use standalone dry processes. Hence, the only wastes associated with these systems would be the spent filters. Alternative 1 has the largest volume of waste to be disposed of (i.e., the sand) and therefore poses the greatest potential environmental impacts (landfill space and possible contamination) of the alternatives. Alternative 3 would produce less waste material than alternative 2 , although only relative quantities can be estimated at this time.

\section{Energy}

Energy requirements for the three alternatives are associated with operating a sufficiently large exhaust $f a n(s)$ to overcome the pressure drop of each system (as the final exhaust temperature of $26.7^{\circ} \mathrm{C}\left(80^{\circ} \mathrm{F}\right.$ ) is within the operating range of the filters). Based on the anticipated pressure drops of the initial control stage of each alternative (see Appendix $B$ ), alternative 2 (sand filter pressure drop $=11 \mathrm{in}$. WC) would have the highest energy impacts of the alternatives, followed by alternative 1 (fiber filter pressure drop $=8 \mathrm{in}$. $W C$ ) and alternative 3 (HEPA pressure drop $=4 \mathrm{in}$. $W C$ ). 
$\mathrm{DOE} / \mathrm{RL} 89-20$

\section{$\underline{E \text { Eonomic }}$}

Installed costs of the three alternatives are presented below, based on previously installed exhaust cleaning systems at various nuclear fuel reprocessing plants (Burchsted et al. 1976).

\author{
Alternative 1 (deep-bed fiber and HEPA) \\ Alternative 2 (deep-bed sand filter only) \\ Alternative 3 (two-stage HEPA)
}

\author{
Cost $\left(\$ / \mathrm{ft}^{3} / \mathrm{min}\right.$ \\ 30.34 \\ 46.88 (cost of additional \\ 7.43
}

These cost estimates show that alternative 3 costs only about $24 \%$ of alternative 1 and $16 \%$ of alternative 2 (percentage would be less if costs of HEPA were include in alternative 2). Although operating costs such as utilities, maintenance, operations, service life, and consumables are not available, it has been shown that alternative 2 has the highest utility cost (largest fan requirements) and higher overall operating costs than alternative 1 (Moore and Fullam 1984). Alternative 1 has the second highest utility cost and alternative 3 has the lowest utility cost. On the other hand, alternative 3 is expected to have higher maintenance costs than alternative 2 because of the frequency of filter changeouts.

\section{Summary}

Alternative 3 is considered to be the BARCT for the final FCFS exhaust. Its use of available proven control methods for reducing radionuclides is confirmed by comparing its effectiveness to the other available alternatives. It is the most cost effective alternative, having the lowest capital and operating costs. Alternative 3 also has the lowest energy consumption of the three systems evaluated.

\subsection{ANALYSIS OF PRESENT AIR QUALITY AT THE PROPOSED SOURCE LOCATION}

- Radionuclides are the only regulated pollutants of concern projected to be emitted by the proposed source in significant quantities, as "significant quantities" are defined by PSD regulations. Therefore, the analys is of present air quality at the proposed site has been limited to impacts of ambient radionuclide concentrations.

The following data were taken from PNL-6825, Hanford Site Environmental Report for Calendar Year 1988, (provided to the Department of Ecology on publication.) The AIRDOSE-EPA (Clean Air Act Code) computer code was used by PNL to develop the offsite dose data. 
Radiological airborne emissions from the proposed project site (400 Area) for calendar year 1988 were as follows:

$$
\begin{array}{ll}
{ }^{90} \mathrm{Sr} & 2.1 \mathrm{E}-05 \mathrm{Ci} \\
{ }^{131 \mathrm{I}} & 1.0 \mathrm{E}-05 \mathrm{Ci} \\
{ }^{41} \mathrm{Ar} & 3.7 \mathrm{E}+01 \mathrm{Ci}
\end{array}
$$

These radionuclides combine for an effective dose equivalent (whole body dose) to the maximally exposed offsite individual of $2 \mathrm{E}-04 \mathrm{mR}$. The same report states that the effective dose equivalent to the maximally exposed offsite individual from all Hanford Site operations air emissions is $0.3 \mathrm{mR}$. Thus, current air quality at the proposed project site is responsible for less than $0.1 \%$ of the total Hanford Site dose to the maximally exposed offsite individual.

These doses can be compared to regulatory limits set by WAC 402-80-50 and WAC 173-480-040. The cited regulations set a whole body dose 1 imit to the maximally exposed offsite individual of $25 \mathrm{mR} / \mathrm{yr}$. The average dose to the maximally exposed offsite individual from 400 Area airborne emissions in 1988 is less than $0.001 \%$ of the regulatory limit.

\subsection{ANALYSIS OF THE PROPOSED SOURCE ON AMBIENT AIR QUALITY}

Again, radionuclides are the only regulated pollutants of concern projected to be emitted by the proposed source in significant quantities, as significant is defined by PSD regulations. Therefore, the analys is of the impact of the emissions from the proposed source on ambient air quality has been limited to impacts of projected ambient radionuclide concentrations.

\subsection{MODEL DESCRIPTION}

The AIRDOSE-EPA (Clean Air Act Code) computer code was used to calculate the dose from FCFS to the maximally exposed offsite individual.

Meteorological data input to the AIRDOSE-EPA code include mixing height, rainfall rate, average air temperature, vertical temperature gradient, wind direction frequency, wind speed, and atmospheric stability. This information was obtained from the data base compiled by the Hanford Meteorological Station (HMS). The HMS data on airspeed, direction, and temperature are collected at a $125-\mathrm{m}(410-\mathrm{ft})$ tower located on the Hanford site between the 200 East and 200 West Areas, and at a second tower at the 400 Area. Wind speed and direction are based on hourly data collected at the 400 Area meteorological tower 10-m (32.8-ft) level during the years 1983 to 1987 . Atmospheric stability was estimated from the temperature gradient between the 9.1 -m and $61-\mathrm{m}(30-\mathrm{ft}$ and $200-\mathrm{ft})$ levels at the HMS for the same period using standard methods of the 
U.S. Nuclear Regulatory Commission (NRC). Air temperature and mixing height are also 5-yr averages of hourly data. Temperature is measured at the tower $61-m(200-f t)$ level, and mixing height data are collected by onsite acoustic sounders.

Joint frequency data, as reported by the HMS, are modified for input into AIRDOSE-EPA by conversion to true average and reciprocal average wind speeds for each direction and stability class. The meteorological data are then used to calculate $X / Q$ values for each radionuclide, which are also a function of radiological half-life and dry deposition velocity. For purposes of this calculation, deposition velocities are assigned as follows: $1.0 \times 10^{-3} \mathrm{~m} / \mathrm{s}$ for all particulate materials, $1.0 \times 10^{-2} \mathrm{~m} / \mathrm{s}$ for iodine isotopes, and zero for all gases.

Source Terms: Projected annual releases from FCFS as presented in Tables 1-1 and 1-3.

Release Height: The FMEF stack height is $36 \mathrm{~m}(117 \mathrm{ft})$.

Inhalation Rate: $8,500 \mathrm{~m}^{3} / \mathrm{yr}\left(300,173 \mathrm{ft}^{3} / \mathrm{yr}\right)$.

Maximally Exposed Individual: Doses were estimated for an individual 1iving $8.7 \mathrm{~km}$ (5.4 mi) south of the 427 Building.

Meteorology: The HMS data and onsite meteorological data, as discussed above.

\subsection{RESULTS OF MODELING ANALYSIS}

As stated in Section 7.0, total 1988 airborne radiological emissions from the Hanford Site resulted in $0.3 \mathrm{mR}$ whole body dose to the maximally exposed offsite individual. Table 1-7 shows that the projected doses from FCFS controlled airborne radiological emissions to the maximally exposed offsite individual are $1.5 \times 10^{-3} \mathrm{mR}$ to the whole body. The airborne radiological emissions from FCFS will then constitute $5.0 \times 10^{-3}$ of the whole body dose to the maximally exposed offsite individual from airborne radiological emissions from all Hanford Site operations, based on 1988 data.

The natural background radiation dose for the Tri-Cities area of Washington State is estimated to be $300 \mathrm{mR}$. The projected dose from the FCFS would be $5.0 \times 10^{-6}$ of natural ambient radiation. 
Table 1-7. Offsite Dose Estimates for an Individual Receiving Maximum Exposure to Airborne Radiological Emissions from Fueled Clad Fabrication System (mR)

Whole body

Other $\quad 220 \mathrm{Rn}+\mathrm{D} \quad$ Other nuclides

\begin{tabular}{|c|c|c|}
\hline $220 \mathrm{RI}$ & nuclides & Total \\
\hline $.0 \mathrm{E}-04$ & $7.0 E-04$ & $1.5 E-03$ \\
\hline
\end{tabular}

\subsection{DEMONSTRATE THAT PROPOSED EMISSIONS WILL NOT CAUSE A VIOLATION OF STATE OR NATURAL AMBIENT AIR QUALITY STANDARDS}

Both WAC 402-80-50 and WAC 173-480-040 state the following:

The WDOE ambient standard requires that emissions of radionuclides to the air shall not cause a dose equivalent of more than $25 \mathrm{mrem} / \mathrm{y}$ to the whole body or $75 \mathrm{mrem} / \mathrm{y}$ to a critical organ of any member of the public.

National ambient air quality standards for U.S. Department of Energy (DOE) facilities are stated in 40 CFR 61.92 as follows:

Emissions of radionuclides to air from DOE facilities shall not exceed those amounts that cause a dose equivalent of $25 \mathrm{mrem} / \mathrm{y}$ (to the whole body or $75 \mathrm{mrem} / \mathrm{y}$ to the critical organ of any member of the public.

If the projected airborne radionuclide doses from FCFS, as listed in Table 1-7, to the maximally exposed offsite individual are added to the historic releases for 1988, it is clear that FCFS emissions will not cause a violation of either State or Federal standards.

\subsection{DEMONSTRATE THAT PROPOSED EMISSIONS WILL NOT CAUSE AN EXCURSION OVER PSD INCREMENTS FOR PARTICULATE MATTER AND SULFUR DIOXIDE}

No sulfur dioxide will be emitted by the FCFS; therefore the PSD sulfur dioxide increments are not applicable.

Because the proposed project will not meet significant emission levels for particulate matter as defined by 40 CFR 52.21 , no air quality impact analyses are required for particulate matter. 


\subsection{DEMONSTRATE THAT PROPOSED EMISSION WILL NOT IMPAIR VISIBILITY IN A CLASS I AREA OR OTHER SENSITIVE AREAS}

Because the proposed source will not be constructed within $10 \mathrm{~km}$ $(6.2 \mathrm{~km})$ of a Class I Area, 40 CFR 52.21 states that demonstrations of visibility impact are not required.

\subsection{DISCUSS THE PROPOSED PROJECT'S EFFECTS ON RESIDENTIAL OR COMMERCIAL GROWTH, VEHICULAR TRAFFIC, SOILS, VEGETATION, ACID DEPOSITION AND ANY OTHER AIR QUALITY RELATED VALUES}

The proposed project will have no impact on residential or commercial growth or vehicular traffic because the proposed project will be located on the Hanford Site, a Federal Government public exclusion area.

The following, taken.from the Hanford Site Environmental Report for Calendar Year 1988 (Jacquish 1989), describes the Hanford Site area soil and vegetation monitoring program and states the results of that program for 1988.

Surface soil and rangeland vegetation samples were collected at a number of locations during 1988, both on and off the Hanford Site. The purpose of sampling was to detect the possible build-up of radionuclides from the deposition of-airborne effluents released from Hanford facilities. Samples were collected at nonagricultural, relatively undisturbed sites so that natural deposition and build-up processes would be represented.

An assessment of radionuclide contributions from Hanford operations was made by comparing results from samples collected 1) on Site with those collected off Site 2) around the site perimeter with those collected at distant locations, and 3) downwind (primarily east and south of the Site) with those collected from generally upwind and distant locations. In addition, results obtained from each location in 1988 were compared to results obtained from the same location in previous years. Evaluations of 1988 results provided no indication of trends or increases in the concentrations of radionuclides in the offsite environment that could be attributed to Hanford operations.

A detailed description of the results of this study can be found in Chapter 4.5 of the publication cited.

In light of these study results, an increase of emissions on the order of magnitude discussed $\left(10^{-3}\right)$ indicates that the proposed project will have little measurable effect on soils or vegetation in the area. 


\section{REFERENCES}

Burchsted et a1. 1976, Nuclear Air Cleaning Handbook-Design, Construction, and Testing of High-Efficiency Air Cleaning Systems for Nuclear Application, C.A. Burchsted, J.E. Kahn, and A.B. Fuller, ERDA-76-21, Oak Ridge National Laboratory, Oak Ridge, Tennessee.

Jacquish, R.E. 1989, Hanford Site Environmental Report for Calendar Year 1988, PNL-6825, Pacific Northwest Laboratory, Richland, Washington.

McDowell et al. 1976, Penetration of HEPA Filters by Alpha Recoil Aerosols, W.J. McDowe11, and F.G. Seeley (Oak Ridge National Laboratory), and M. T. Ryan (University of Lowe11, Massachusetts), 14th ERDA Air Cleaning Conference, Sun Valley, Idaho, August 11-13, 1976.

Moore, E.B. and H.T. Fullam 1984, Control Technology for Radioactive Emissions to the Atmosphere at U.S. Department of Energy Facilities, PNL-4621-Final, Pacific Northwest Laboratory, Richland, Washington.

Zippler, D.B. 1974, "Evaluation of Multistage Filtration to Reduce Sand Filter Exhaust Activity," Proceedings of the 13th AEC Nuclear Air Cleaning Conference, Vol. 1, San Francisco, California, March 1975, pp. $609-619$. 


\section{Prevention of Significant Deterioration \\ New Source Review for \\ Radioisotope Power Systems Facility}

\subsection{PROJECT LOCATION}

The Radioisotope Power System Facility (RPSF) will be located in the Fue 1 and Materials Examination Facility (FMEF) Process Building on the -5.2-m $(-17-\mathrm{ft})$ and $-10.7-\mathrm{m}(-35-\mathrm{ft})$ levels. Figures 8 and 9 detail those sections of the FMEF to be used by the RPSF.)

\subsection{PROCESS DESCRIPTION}

The RPSF will join encapsulated plutonium oxide fuel pellets (fuel clads) with graphite aeroshells to form general purpose heat source (GPHS) modules (Figure 5). The GPHS modules will be grouped into various numbers and configurations to produce heat source assemblies (HSA). The HSAs will then be used in either radioisotope thermoelectric generators (RTG) (Figure 10) or dynamic isotope power systems (DIPS). The RTGs will be assembled in the RPSF. The DIPSs will assembled at another site. An overall process flow diagram is depicted in Figure 11.

Fuel clads (FC) may be accepted from manufacturing sites other-than FCFS. Those FCs shipped from other manufacturing sites will be removed from their shipping canisters in cell 134 and will be decontaminated in cell 137. These steps will not be performed for the FCs manufactured at the FMEF by the FCFS.

Assembly of the GPHS modules will take place in cells 135 and 136 of the RPSF. A sintered metal vent on four FCs will be activated and two FCs will be inserted into a graphite sleeve. Two graphite sleeves will be inserted into the aeroshell to produce a GPHS module. The assembled GPHS modules will be transferred to cell 138 where they will be loaded into storage canisters. Two GPHS modules will be loaded into each canister and the canister will be welded shut. Each storage canister will be equipped with an isolation valve and a tubing connector. The storage canisters will be transferred to room 229 where carbon monoxide and carbon dioxide contaminants are removed by successive evacuation and back filling of the storage container with argon. (A beneficial side effect of this process is a slight reduction of the $\mathrm{PuO}_{2}$ to about $\mathrm{PuO}_{1.97^{\circ}}$ ) The storage canisters will then be stored in room 229 until they are required for power source assembly.

Before assembly of the HSAs and the RTGS, the GPHS modules must be removed from their storage canisters. This operation will be performed in the decanning chamber in room 226A. The GPHS modules will be assembled 


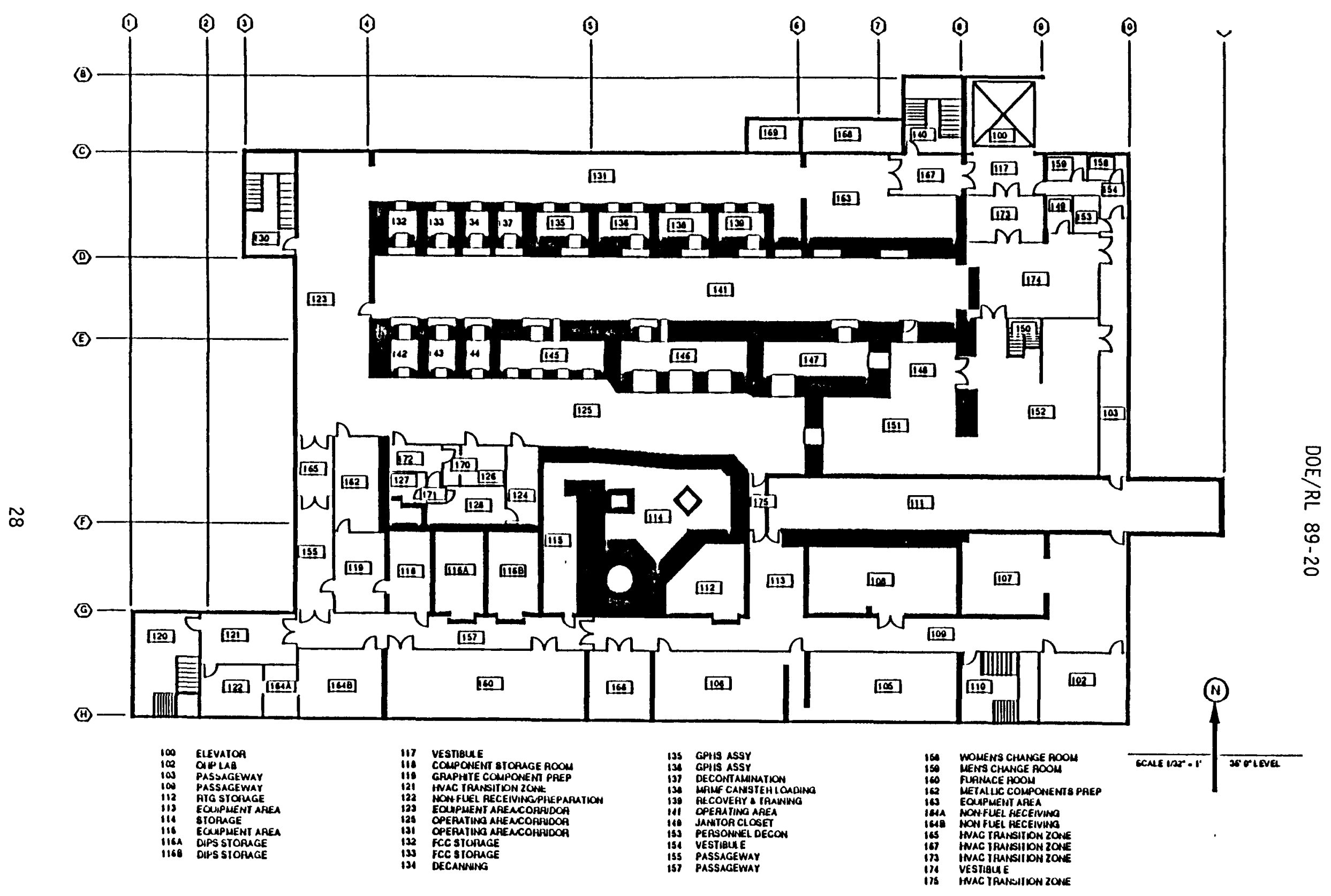

Figure 8. Radioisotope Power Systems Facility

Floor Plan -10.7-Meters (-35-Feet) Elevation. 

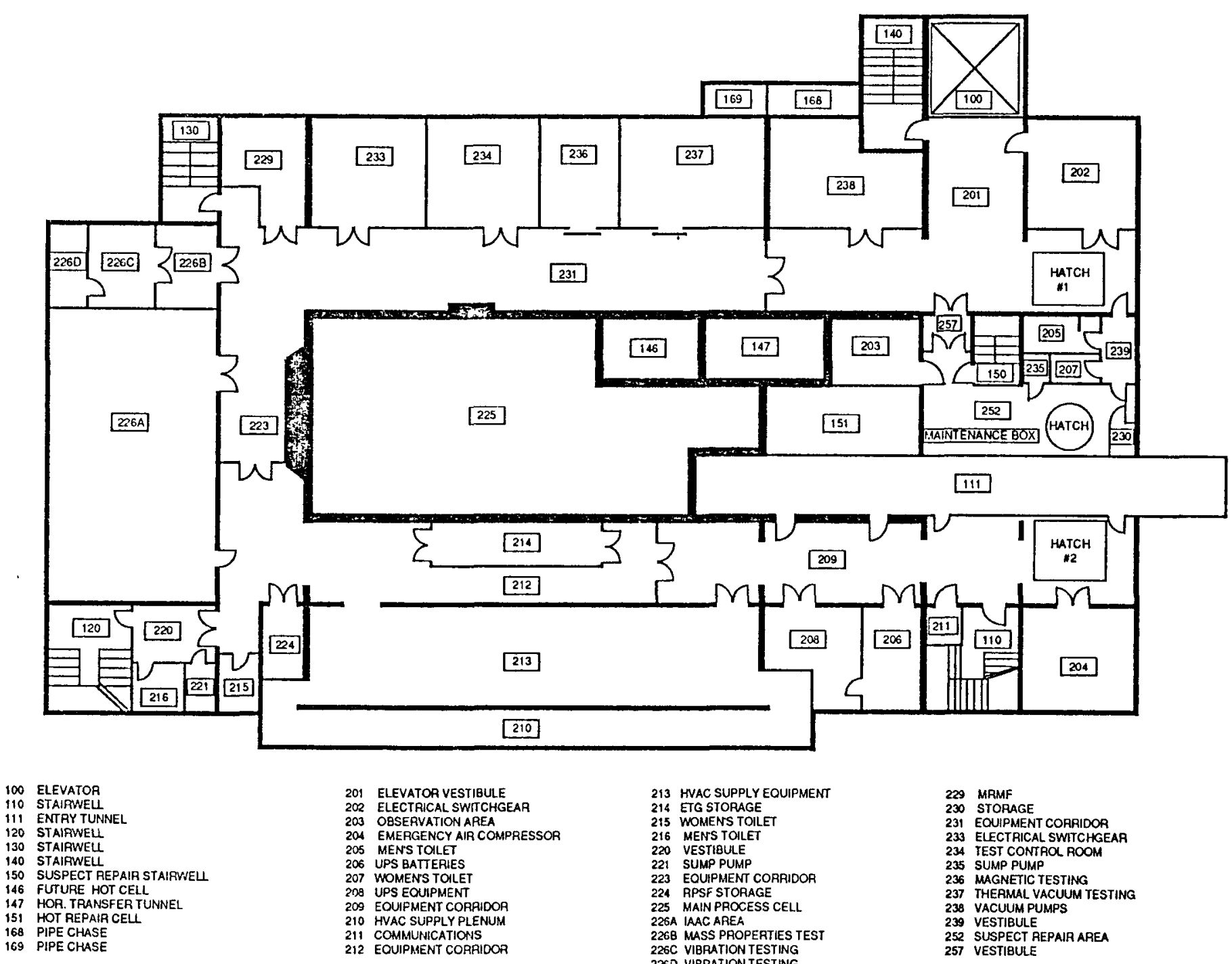

213 HVAC SUPPLY EOUIPMENT

215 WOMENS TOIL

216 MENS TOILET

221 SUMP PUMP

223 EQUPPMENT CORAIDOF

225 MAIN PROCESS CELL

226A IAAC AREA

2260 MASS PROPERTIES TES

226D VIBRATION TESTING

229 MRMF

231 EOUIPMENT CORRIDOR

234 TEST CONYAOL ROOM

235 SUMP PUMP

236 MAGNETIC TESTING

237 THERMAL VACUUM TESTING

239 VESTIBULE

252 SUSPECT REPAIR AREA

VIBRATION TES
AMPUFIEFS

Figure 9. Radioisotope Power Systems Facility Floor Plan -5.2-Meters (-17-Feet) Elevation. 


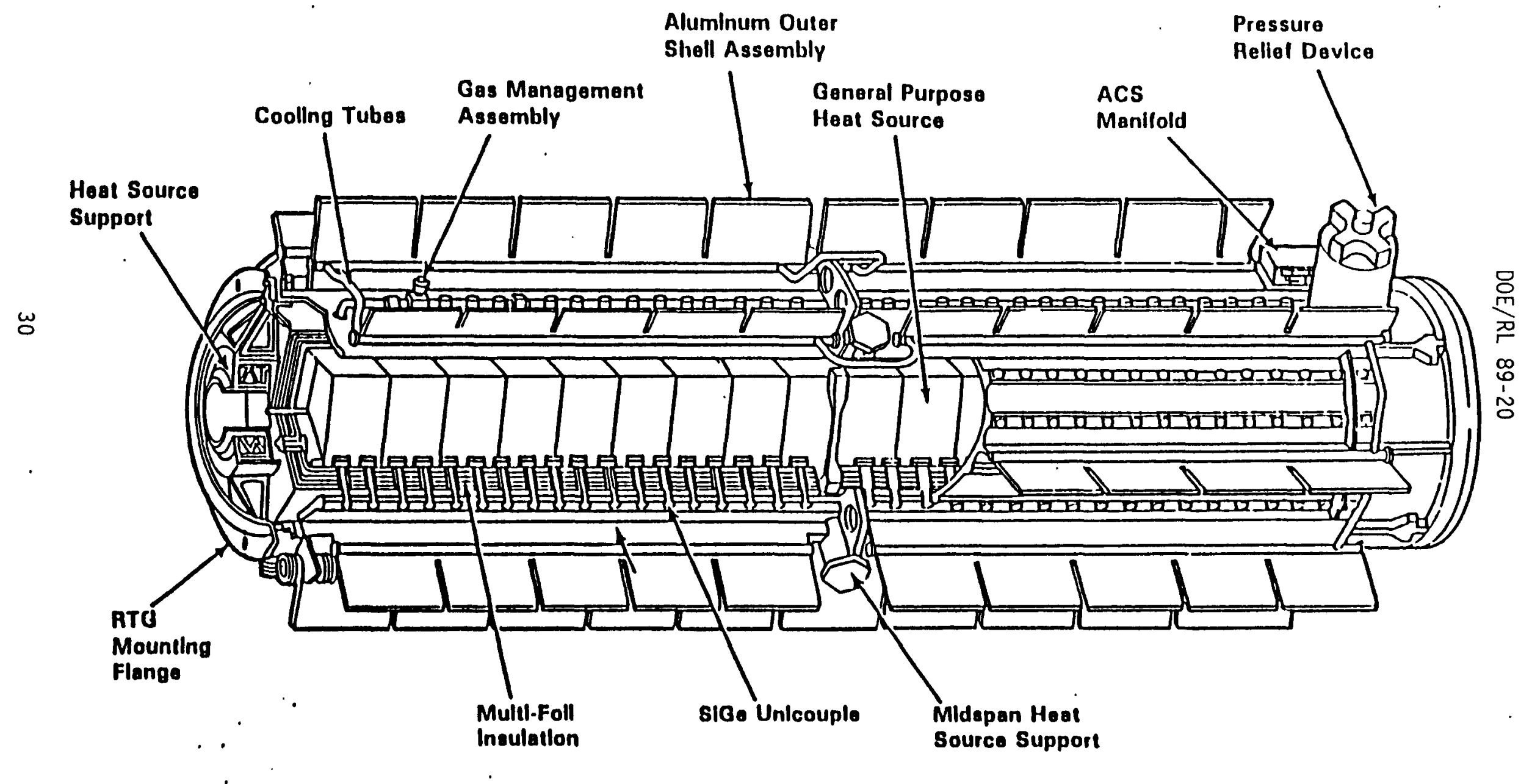

Figure 10. General Purpose Heat Source Radioisotope Thermoelectric Generator. 


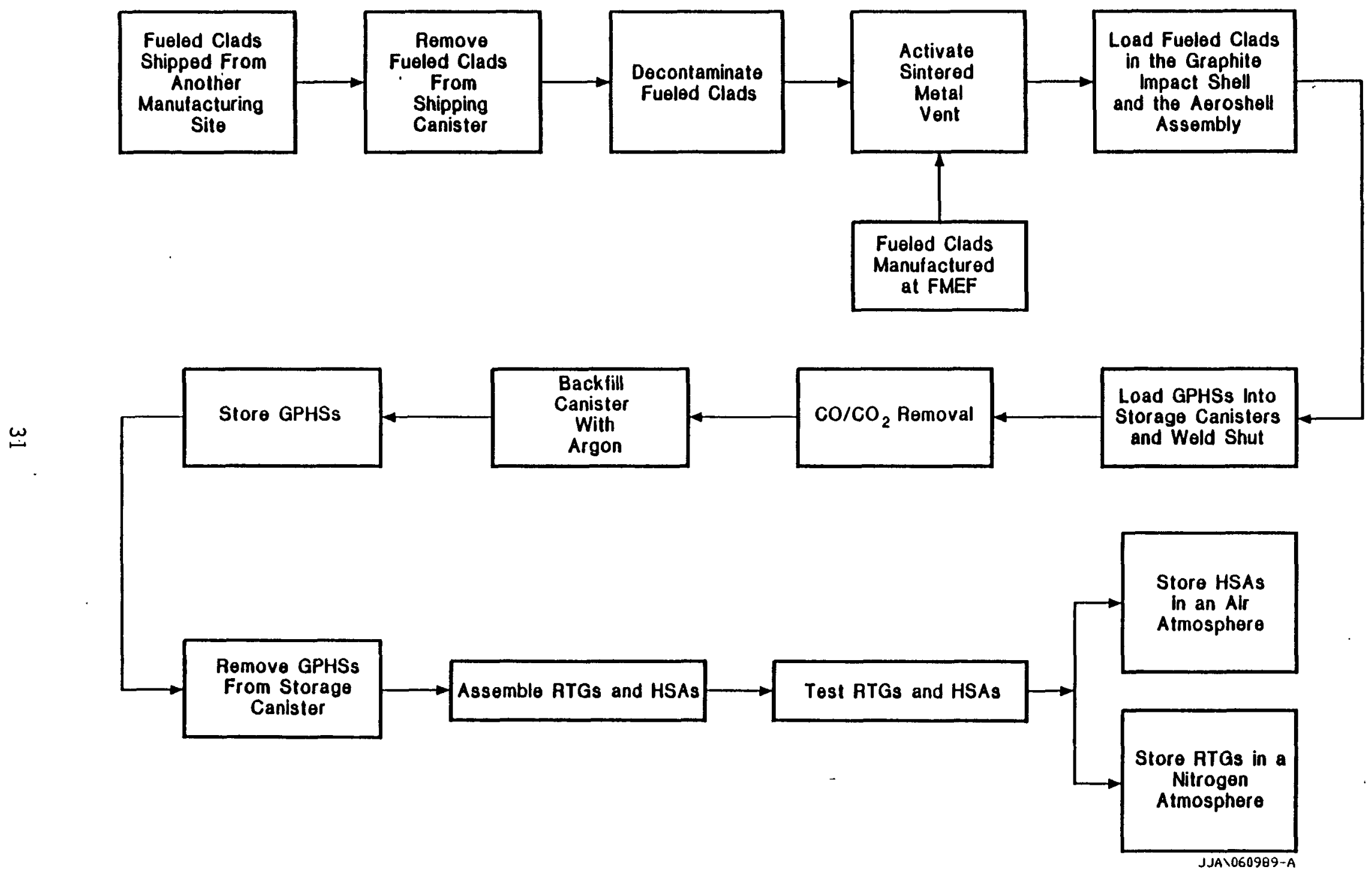

Figure 11. Overall Process Flow Diagram for Radioisotope Power Systems Facility. 
into HSAs and RTGs inside the inert atmosphere assembly chambers located in room 226A. Three inert atmosphere assembly chambers are planned to accommodate the variety of HSAs and RTGs to be produced in the RPSF. The chambers will contain an argon environment and each will have an argon purification system to control oxygen and moisture.

Following assembly, the HSAs and RTGs will be tested as required by the specifications for that power source. The RPSF will have vibration testing, mass properties testing, magnetic properties testing, radiation mapping, and thermal vacuum testing capabilities.

Vibration testing will be provided in room $226 \mathrm{C}$ to subject the completed power sources to random, transient, and shock vibration loads along three discrete axial directions. Mass properties testing will be performed in room 226B. A computer-controlled floating spin table with load cells will be used to determine the center of gravity for the power source. The weight of the power source will also be determined. The magnetic field for the power source will be measured and, if necessary, adjusted in room 236. Radiation mapping will be performed with portable instrumentation in the FMEF shipping and receiving area using instruments capable of measuring neutron flux, neutron energy spectra, gamma flux, and gamma energy spectra. Thermal vacuum testing to determine the performance of the power source in simulated space conditions will be performed in room 237 .

The completed HSAs and RTGS will be stored in the RPSF until they are ready to be used by the customer. Instrumentation to alarm off-normal conditions will be provided to monitor the RTGS and HSAs during storage. The RTGs will be stored in room 112 . Room 112 will have a nitrogen atmosphere to minimize the deleterious effects of oxygen, carbon dioxide, and carbon monoxide on the thermoelectric components. The HSAS will be stored in rooms $116 \mathrm{~A}$ and $116 \mathrm{~B}$ until shipped off site to be joined with the generator systems. Rooms $116 \mathrm{~A}$ and $116 \mathrm{~B}$ will have an air atmosphere.

\subsection{SOURCES OF EMISSIONS}

The RPSF will be provided with ventilation Zones I, II, and III. Areas denoted Zone I will contain the radioactive materials being processed and will be separated from surrounding ventilation Zone II areas. Ventilation Zone III areas will be those support areas that bound ventilation Zone II. There will be a negative pressure gradient from Zone III to I so that any contaminants will flow into Zone I and through the facility emissions abatement systems. All Zone I air flows out the FMEF (RPSF/FCFS shared) stack.

Releases of radioactive materials to the ventilation system will occur in Zone I and may occur in Zone II. Releases of radioactive materials to the ventilation system from Zone III are unlikely. Figure 12 depicts RPSF cell air flow and indicates points of emission to the air. The RPSF activities taking place in each cell are summarized below. 


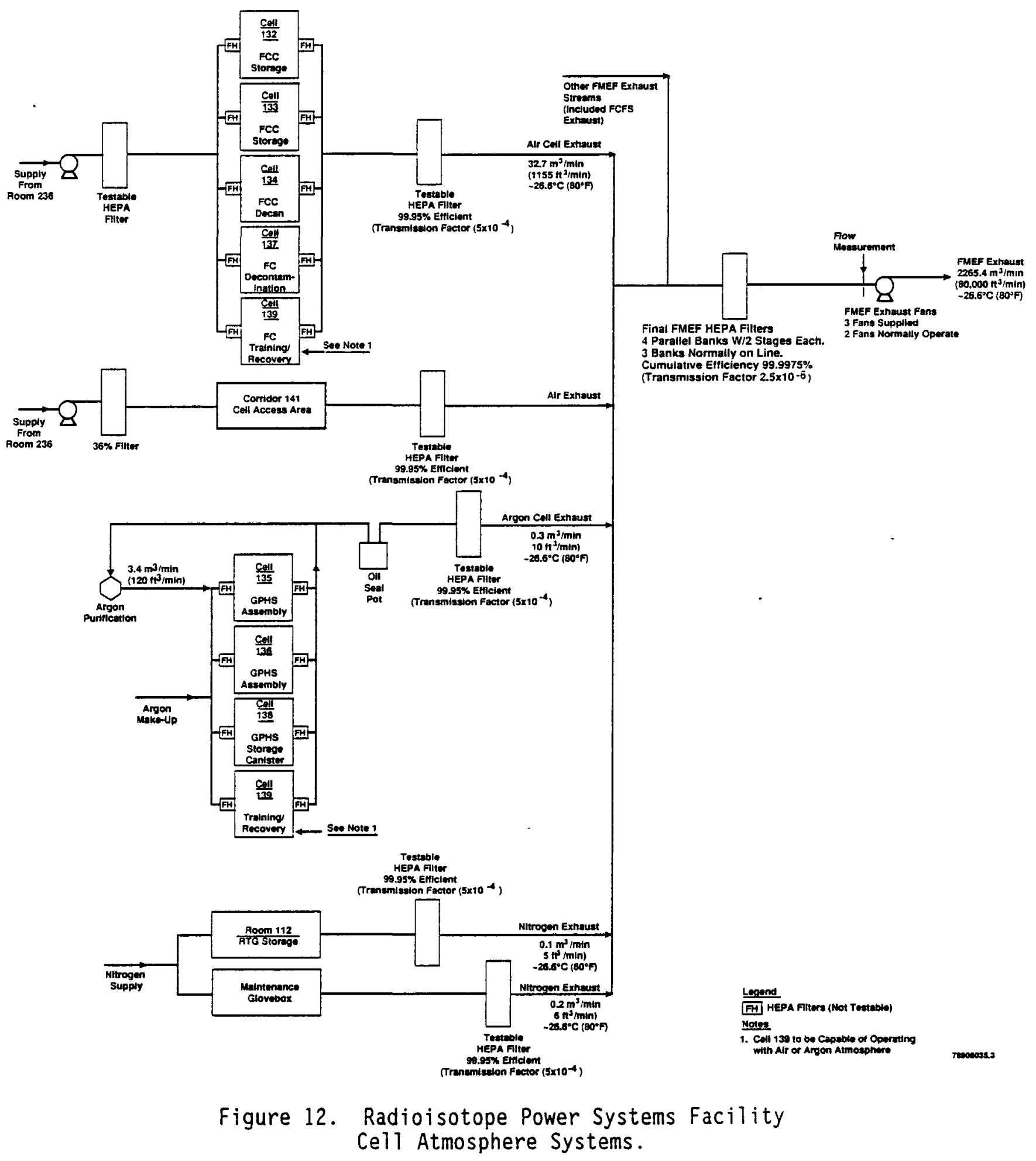




\section{1 .1 Zone 1}

Cells 132, 133, 134, 135, 136, 137, and 138 will be part of the Zone I ventilation system. These enclosures will be used to assemble the FCs into GPHS modules. One percent of the plutonium dioxide contaminating the surface of the $F C S$ is assumed to be released to the ventilation system during the assembly process.

The exhausts from the inert atmosphere assembly chambers, room 112 , the room 229 vacuum pumps, and the room 237 thermal vacuum chambers will contain inert gases. These areas will be connected to the Zone I exhaust because of a concern for breathing air safety rather than radionuclide control.

\subsubsection{Zone II}

Rooms 123, 125, 131, 141, and 163 will be part of the Zone II ventilation system. Releases of radioactive materials to the Zone II ventilation system are not likely to occur because of the pressure differential between Zone I and Zone II and because there are backdraft dampers (acting as check-valves) between Zone II and Zone III.

\subsubsection{Zone III}

Zone III includes those areas surrounding the Zone II ventilation area. Releases of radioactive materials to the Zone III ventilation system are highly unlikely because of the negative pressure differential and because no radioactive material will be stored or prociessed in Zone III. (Radioactive materials in transport containers will pass through Zone III to Zones I and II.)

\subsection{DESIGN AND OPERATING PARAMETERS}

\subsection{HOURS OF OPERATION}

The RPSF is intended to operate $8 \mathrm{~h} / \mathrm{d}, 5 \mathrm{~d} / \mathrm{wk}, 52 \mathrm{wk} / \mathrm{yr}$ (including maintenance downtime).

\subsection{NORMAL AND MAXIMUM PRODUCTION RATES}

Production rates are stated in terms of GPHS modules. The normal production rate is 240 modules/yr. The theoretical "maximum" production rate is 384 modules/yr. (The maximum production rate was developed assuming no need to shut down any plant process equipment for maintenance, or any other reason whatsoever, for a period of $1 \mathrm{yr}$. ) 


\subsection{FUEL REQUIREMENTS}

The fuel used by FMEF and its enclosed activities, including RPSF, is electricity. The base load for FMEF and its utilities is estimated to be $10^{6} \mathrm{~kW} / \mathrm{h}$ annually. The incremental load for RPSF is estimated to be $2.25 \times 10^{6} \mathrm{~kW} / \mathrm{h}$ annually.

\subsection{RAW MATERIAL REQUIREMENTS}

The RPSF will not fabricate a product from raw material. The RPSF will assemble GPHS modules using FCs fabricated by the FCFS or at another location and graphite aeroshells fabricated outside the FMEF complex.

As stated in Section 3.2, the RPSF will have the capability to produce 240 GPHS modules annually at normal operating levels. Each GPHS module contains four FCs in one graphite aeroshell. Thus, to maintain production levels at the normal rate would require 960 FCs and 240 graphite aeroshells.

Additionally, the following agents will be used as described and are therefore considered raw materials.

- Methylene chloride: degreasing agent; less than $1892 \mathrm{~L} / \mathrm{yr}$ (500 gal/yr)

$0 \quad$ Ethyl alcohol: degreasing agent; less than $1892 \mathrm{~L} / \mathrm{yr}$ (500 gal/yr)

- Deionized water: decontamination agent; less than $1892 \mathrm{~L} / \mathrm{yr}$ ( $500 \mathrm{gal} / \mathrm{yr})$

- Nitric acid: decontamination agent; less than $189 \mathrm{~L} / \mathrm{yr}$ (50 gal/yr)

o Hydrofluoric acid: decontamination agent: less than $189 \mathrm{~L} / \mathrm{yr}$ (50 gal/yr)

o Borden's Resinox SC-1008: graphite adhesive: less than $0.9 \mathrm{~L} / \mathrm{yr}$ (1 qt/yr)

\subsection{EMISSIONS CONTROL SYSTEM}

Because the radioactive airborne emissions from RPSF will consist primarily of particulate matter generated during the assembly of GPHS modules (Section 2.1), the emissions control system must be capable of containing micrometer- and submicrometer-size particles.

As discussed in Section 2.1, the RPSF operations are provided with ventilation Zones I, II, and III with a negative pressure gradient from Zone III to Zone I to provide maximum confinement of radioactive contamination. Zone I will be operated at $-1.00 \pm 0.25$ in. WG pressure relative to outside atmosphere. Zone II will be operated at $-0.25 \pm 0.05 \mathrm{in}$. WG pressure relative to outside atmosphere. Zone III will be operated at $-0.10 \pm 0.05$ in. WG pressure relative to outside atmosphere. 
Zone I ventilation areas in which the GPHS modules are assembled use a recirculated argon atmosphere, while the remaining Zone I hot cells use an air atmosphere. Special sealed structures and structural penetrations are implemented to separate Zone I and Zone II areas. Zone I and Zone II exhausts are vented to separate primary high-efficiency particulate air (HEPA) filtration steps before being combined and routed to final filtration consisting of three banks of HEPA filters and subsequently discharged to he atmosphere. Zone III exhaust is ultimately routed along with other plant exhausts to the final HEPA filtration step and discharged to the atmosphere.

Provision of both primary and final particulate control measures as described above, allows for high-efficiency removal and provides system redundancy in the event of a possible failure of one of the emission control units. In addition, the RPSF Zone I cells are equipped with non-testable HEPA filters on both the inlet and outlet flows to minimize the radionuclide contamination of the connected atmosphere control systems.

Final high-efficiency particulate filtration before discharge of the radionuclide-contaminated gases to the atmosphere is a nuclear industry standard. Generally, two-stage filtration is used for this purpose. Presently employed final filtration techniques in the nuclear industry include combination prefilter and HEPAs, deep-bed glass-fiber filters, and deep-bed sand filters. The best available radionuclide control technology (BARCT) assessment developed for this proposed project demonstrated that the prefilter and HEPA system provides the highest degree of removal efficiency (see Section 6.0).

\subsection{EMISSIONS - TYPE AND QUANTITY}

\subsection{REPRESENTATIVE EMISSIONS FROM THE EXISTING SOURCE}

The FMEF was designed and constructed to produce production- and testfuel assemblies for the Liquid Metal Reactor program and provide a capability for examining fuels and materials following irradiation. These FMEF missions were cancelled before introducing fuel material or other irradiated material into the facility.

The only emissions from the RPSF/FCFS stack have been from the HVAC system functioning to heat or cool the facility. The average temperature at the stack is $26.6^{\circ} \mathrm{C}\left(80^{\circ} \mathrm{F}\right)$. The average stack flow rate is $2,265 \mathrm{~m}^{3} / \mathrm{min}$ $\left(80,000 \mathrm{ft}^{3} / \mathrm{min}\right)$.

\subsection{PROJECTED ACTUAL CONTROLLED EMISSIONS}

The controlled release rates for radionuclides from the RPSF were calculated based on an annual throughput of 960 FCs. Since the FCs have been decontaminated for shipping purposes, the surface contamination is estimated to be only $8.6 \times 10^{-6} \mathrm{Ci} / \mathrm{yr}$. (Shipping requirements are no more than 
$20,000 \mathrm{dpm} / \mathrm{FC}$. There are $4.5 \times 10^{-13} \mathrm{Ci} / \mathrm{dpm}$, and there are $\left.960 \mathrm{FCs}.\right)$ A Release Adjustment Factor (RAF) of $2.5 \times 10^{-10}$ was then applied to the $8.6 \times 10^{-6} \mathrm{Ci} / \mathrm{yr}$.

The RAF assumes that 1 percent (the "release factor") of the $\mathrm{PuO}_{2}$ powder contaminating the capsule surfaces will become entrained in the cell atmosphere and pass into the ventilation system. (This is an extremely conservative assumption because there are non-testable HEPA filters between the gloveboxes and the ventilation system. The HEPAs are $99.97 \%$ efficient upon installation. Therefore, for $1 \%$ of the entire throughput to become contained in the ventilation system, over $100 \%$ of the entire throughput would have to be released.) The ventilation system is assumed to contain three HEPA filters in series, which is equivalent to a transmission factor of $2.5 \times 10^{-8}$. (It is understood that aggregate particles from a source of alpha activity appear to penetrate HEPA filters much more effectively than would be expected on the basis of filter efficiency for similar sized stable aerosols. It is also understood [McDowell et al. 1976] that where the aerosols are realistic in terms of what comes out of the facility, the recoil effect is not proven. In light of the possibility of the recoil effect, monitoring, appropriate filter changeouts, and other administrative controls will be implemented to ensure filter system integrity.) The RAF is the product of the release factor and the transmission factor. For purposes of the dose calculation, the RPSF is assumed to contain only three HEPA filters in series. The gloveboxes, hoods, and enclosures actually have an additional HEPA filter, however this filter is not testable, and the removal efficiency cannot be verified during operation. Therefore, no credit is taken for these HEPA filters in the dose calculations. The particulate radionuclide emission rates for the RPSF are shown below in Table 2-1.

Table 2-1. Controlled Particle Radionuclide Emission rates

(Actual) for Radioisotope Power Systems Facility ( $\mathrm{i} / \mathrm{yr}$ )

(Emissions at Stack).

Nuclide

$$
\begin{aligned}
& 236 \mathrm{Pu} \\
& 238 \mathrm{Pu} \\
& 239 \mathrm{Pu} \\
& 240 \mathrm{Pu} \\
& 241 \mathrm{Pu} \\
& 242 \mathrm{Pu}
\end{aligned}
$$

Emission rate

$5.58 E-19$

$1.99 \mathrm{E}-15$

$6.27 E-19$

$2.98 \mathrm{E}-19$

$2.30 \mathrm{E}-16$

$8.77 \mathrm{E}-21$

The controlled emission rates of gaseous radionuclides ( $220 \mathrm{Rn})$ for the RPSF were conservatively calculated from the total amount being generated within the fuel material being handled. In reality, a large fraction of the $220 \mathrm{Rn}$ will decay before it leaves the fuel because it has a half-life of only $55.6 \mathrm{~s}$. Because the vent rate from the cells is controlled at the lowest flow rate possible to protect the comparatively expensive argon environment, 
$220 \mathrm{Rn}$ is held up with the argon. The emission rate of $220 \mathrm{Rn}$, therefore, is equal to the initial $220 \mathrm{Rn}$ activity reduced by the factor 0.0032 to take into account decay during holdup. The factor 0.0032 is developed as follows:

The amounts of radon shown as released take into consideration the holdup in the argon filled cells before release to the exhaust system. These cells have a combined volume of about $5000 \mathrm{ft}^{3}$, with a combined total exhaust flow rate of $12 \mathrm{ft}^{3} / \mathrm{min}$. The ventilation removal rate is then $L V=\left(12 \mathrm{ft}^{3} / \mathrm{min}\right) /\left(5,000 \mathrm{ft}^{3}\right)=0.0024 / \mathrm{min}$. Including the decay of the $220 \mathrm{Rn}$ gives a resultant factor of $0.0032=\mathrm{LV} /[\mathrm{L}(220)+\mathrm{LV}]$ to correct for decay during holdup in the argon cells.

A small correction was also applied for decay in transit through the ventilation system. The duct diameter was assumed to be 3 in., giving a linear flow rate of $4.1 \mathrm{ft} / \mathrm{s}$ down the duct. The distance travelled to the main exhaust duct was assumed to be $10 \mathrm{ft}$, so that 0.97 was the decay correction.

The RPSF is assumed to handle $145 \mathrm{~kg}(319.6 \mathrm{lb})$ of $238 \mathrm{PuO}_{2}$ per year. For conservatism, the inventory during the year is assumed to equal an entire year's production.

The amount of $220 \mathrm{Rn}$ release from the facility depends upon the initial radon activity (which is determined by the $236 \mathrm{Pu}$ impurity concentration, the preprocessing decay time of $236 \mathrm{Pu}$, and the residence time of $220 \mathrm{Rn}$ inside the facility before being emitted) multiplied by the above described decay factors. The specific maximum release rate data for these factors are listed below, in Table 2-2.

\section{Table 2-2. Input for $220 \mathrm{Rn}$ Emissions (Actual)} Calculations for RPSF.

Facility plutonium inventory: Initial $236 \mathrm{Pu}$ impurity:

Pre-processing decay time:

Facility residence time:
$145.0 \mathrm{~kg}(319.6 \mathrm{lb}) 238 \mathrm{PuO}_{2}$ $2.0 \mathrm{p} / \mathrm{M}$

6.0 month

52.0 week

Based on the above, the actual controlled random emission rate for the RPSF equals $275 \mathrm{Ci} / \mathrm{yr}$.

\subsection{PROJECTED POTENTIAL CONTROLLED EMISSIONS}

The following discussion and analysis provides releases from theoretical production rates. The RPSF is being designed for a production rate of 240 GPHS modules/yr.

The factor $384 / 240$ in the above equation, adjusts the production rate to maximum efficiency. The controlled particle radionuclide emission rates are based on a production rate of 240 GPHS modules per year. The $240 \mathrm{GPHS}$ modules per year production rate would result from plant operations at 
expected efficiency, and $5 \mathrm{~d} / \mathrm{wk}$. Operations at $100 \%$ efficiency, $8 \mathrm{~h} / \mathrm{d}$ and $5 \mathrm{~d} /$ wk would result in a production rate of 384 GPHS modules per year.

The projected potential controlled particulate radionculide emission rates for the RPSF are shown below in Table 2-3. The projected potential controlled gaseous radionuclide emission rate for the RPSF follows Table 2-3.

- Table. 2-3 Controlled Particle Radionuclide Emission Rates (Potential) ( $\mathrm{C} i / \mathrm{yr}$ ) (Emissions at Stack)

Nuclide

$$
\begin{aligned}
& 236 \mathrm{Pu} \\
& 238 \mathrm{Pu} \\
& 239 \mathrm{Pu} \\
& 240 \mathrm{Pu} \\
& 241 \mathrm{Pu} \\
& 242 \mathrm{Pu}
\end{aligned}
$$

Based on the above, the controlled potential radon emission rate for the RPSF is $1852 \mathrm{Ci} / \mathrm{yr}$.

\section{Emission rate}

$3.75 E-18$

$1.34 E-14$

$4.22 E-18$

$2.00 E-18$

$1.55 \mathrm{E}-15$

$5.90 E-20$

\subsection{ANTICIPATED CONSTRUCTION SCHEDULE}

The following schedule is projected:

Start of design (conceptual)

Completion of design (definitive)

Start of major equipment procurement

Completion of major equipment procurement

Start of construction (pre-construction

activities)

Completion of construction
December 1987

September 1991

October 1989

January 1992

January 1990

April 1992

\subsection{A DEMONSTRATION OF BEST AVAILABLE CONTROL TECHNOLOGY (BACT) SELECTION}

Radionuclides are the only regulated pollutants of concern projected to be emitted by the proposed source in significant quantities, as defined by prevention of significant deterioration (PSD) regulations. Therefore, the demonstration of BACT has been limited to impacts of ambient radionuclide concentrations, or a demonstration of best available radionuclide control technology (BARCT). 
A BARCT is defined by WAC $-480-60$ as follows:

Technology which will result in a radionuclide emission limitation based on the maximum degree of reduction for radionuclides which would be emitted from any proposed stationary source or modification of a source which the permitting authority on a case-by-case basis, taking into account energy, environmental, and economic impacts and other costs, determines is achievable for such source or modification through application of production processes or available methods, systems, and techniques. In no event shall application of best available radionuclide technology result in emissions of radionuclides which would exceed the ambient annual standard limitation specified in this chapter.

The selection of the emissions control system described in Section 3.5 is as BARCT for the pollutants to be emitted by the RPSF as supported by the discussion in the following sections.

\subsection{CONTROL ALTERNATIVES}

Radionuclide emissions from the RPSF are limited to particulate matter entrained in cell and room exhausts from the handling and decontamination of iridium-encapsulated FC, as discussed in Section 2.0. Because of the anticipated nature of this source (i.e., very low quantities of micrometerand submicrometer-sized particulate matter), only high-efficiency particulate matter controls were investigated through a literature search of industrial and nuclear applications (Appendix A). Mechanical dust collectors used in many industrial applications for the removal of large particulates were not considered for the survey. Potential control devices identified in the surveys are presented in Table 2-4. Detailed process descriptions and evaluations are presented in Appendix B.

Of the potential particulate controls identified in Table 2-6, only the prefilter and HEPA can be applied to primary particulate control in this application.

Table 2-4. Radioisotope Power Systems Facility Control Technology Survey Results.

Particulate matter

HEPA filter

Deep-bed sand filter

Deep-bed glass-fiber filter

High-efficiency mist eliminator

Prefilter
$99.97 \%$ for $0.3-\mu \mathrm{m}$ particles

$99.95 \%$ for $0.3-\mu \mathrm{m}$ particles

$99.9 \%$ for $0.3-\mu \mathrm{m}$ particles

$99.5 \%$ for $1-\mu \mathrm{m}$ particles

$85 \%(\max )$ for $0.3-\mu \mathrm{m}$ particles 
In the nuclear industry, prefilters are generally used in combination with HEPAs to remove the larger particles in the exhaust stream, thus increasing the service life of the HEPAs. Extremely large units, such as the deep-bed sand and deep-bed fiber filters cannot be considered as primary filters because adequate floor space is not available. Although the highefficiency mist eliminator (HEME) is relatively small (about $0.9 \mathrm{~m} \mathrm{[3} \mathrm{ft}$ ] in length), it is significantly less effective than the HEPA in its removal of sma11 particles, it requires additional plumbing (for possible filter cleaning with a water-wash) and it is normally not used for dry room offgas systems. Therefore, a combination prefilter/HEPA assembly is considered the only applicable particulate control alternative based on performance and operating/physical constraints for primary RPSF exhaust treatment, and is thus proposed as BARCT for this particular application. No further analysis of energy, environmental, or economic impacts is required because the control technology identified has been determined to be the technology that is both appropriate and that allows the lowest emission rate of radionuclides. Another control technology would not provide a comparable low environmental impact, regardless of energy or economic impact. The BARCT analys is will be limited therefore to the final filtration processes only.

After primary treatment, all the exhaust from the RPSF operations is combined and routed to a final filtration step before discharge through the main building stack. Final high-efficiency particle filtration before discharge of radionculide-contaminated gases to the atmosphere is a nuclear industry standard. Generally, two-stage filtration is used for this purpose. Presently employed final filtration techniques in the nuclear industry include combination prefilter and HEPAs, deep-bed glass-fiber filters, and deep-bed sand filters (Table 2-4). Deep-bed glass-fiber and sand filters are normally installed upstream of a final contact HEPA filter. Therefore, the alternative control systems for the final RPSF exhaust that will be evaluated are the following:

Alternative 1 - deep-bed glass-fiber filter/one-stage HEPA

Alternative 2 - deep-bed sand filter/one-stage HEPA

Alternative 3 - two-stage HEPA

The following will present an evaluation of these final emission control alternatives based on environmental, energy, and economic impacts to demonstrate BARCT for the RPSF emissions.

\subsection{ENVIRONMENTAL}

Each of the three alternatives incorporates a HEPA filter as the secondstage control device. Studies have shown that the removal efficiency of a HEPA placed downstream of another high-efficiency particulate control device (such as a deep-bed sand filter or another HEPA) is lower than that of a single-stage HEPA (Zippler 1974). It is postulated that this is because of the extraction of the more readily collected particles in the initial filter 
(Moore and Fullam 1984). Sufficient data are not available to determine the effect that this would have on the overall removal efficiency of each control system. For the purposes of this analysis, it is assumed that the secondstage HEPA performs identically for each system. Therefore, the overall efficiency is directly related to the removal efficiency of the first-stage unit. As shown in Table 2-4, alternative 3 (two-stage HEPA) would provide somewhat higher performance than alternatives 2 and 1 . Because ground-level radionuclide impacts are directly dependent on emission rate (and thus removal efficiency), the implementation of alternative 3 would result in the lowest air quality impact.

A11 three alternatives use standalone dry processes. The only wastes associated with these systems would be the spent filters. Alternative 1 has the largest volume of waste to be disposed (i.e., the sand) and therefore poses the greatest potential environmental impact (landfill space and possible contamination) of the alternatives. Alternative 3 would produce less waste material than alternative 2 , although only relative quantities can be estimated at this time.

\subsection{ENERGY}

Energy requirements for the three alternatives are associated with operating a sufficiently large exhaust fan(s) to overcome the pressure drop of each system (since the final exhaust temperature of $26.6^{\circ} \mathrm{C}\left[80^{\circ} \mathrm{F}\right]$ is within the operating range of the filters). Based on the anticipated pressure drops of the initial control stage of each alternative (see Appendix B), alternative 2 (sand filter pressure drop $=11$ in. WC) would have the highest energy impact of the alternatives, followed by alternative 1 (fiber filter pressure drop $=8 \mathrm{in}$. WC) and alternative 3 (HEPA pressure drop $=4 \mathrm{in}$. WC).

\subsection{ECONOMIC}

Installed costs of the three alternatives are presented below, based on previously installed exhaust cleaning systems at various nuclear fuel reprocessing plants (Burchsted et a1. 1976):

\section{$\underline{\operatorname{Cost}(\$ / \mathrm{ft} / \mathrm{min})}$}

Alternative 1 (deep-bed fiber and HEPA)

Alternative 2 (deep-bed sand filter only)

Alternative 3 (two-stage HEPA)
30.34

46.88 (cost of additional

7.43

These cost estimates show that alternative 3 costs only about $24 \%$ of alternative 1 and $16 \%$ of alternative 2 (percentage would be less if costs of HEPA were include in alternative 2). Although operating costs such as utilities, maintenance, operations, service life, and consumables are not available, it has been shown that alternative 2 has the highest utility cost (largest fan requirements) and higher overall operating costs than 
alternative 1 (Moore and Fullam 1984). Alternative 1 has the second highest utility cost and alternative 3 has the lowest utility cost. On the other hand, alternative 3 is expected to have higher maintenance costs than alternative 2 because of the frequency of filter changeouts.

\subsection{SUMMARY}

Alternative 3 is considered to be the BARCT for the final RPSF exhaust. Its use of available, proven control methods for reducing radionuclides is confirmed by comparing its effectiveness to the available alternatives. It is the most cost effective alternative, having the lowest capital and operating costs. Alternative 3 also has the lowest energy consumption of the three systems evaluated.

\subsection{ANALYSIS OF PRESENT AIR QUALITY AT THE PROPOSED SOURCE LOCATION}

Radionuclides are the only regulated pollutants of concern projected to be emitted by the proposed source in significant quantities, as defined by PSD regulations. Therefore, the analysis of present air quality at the proposed source location has been limited to impacts of ambient radionuclide concentrations.

The following data was taken from PNL-6825, Hanford Site Environmental Report for Calendar Year 1988 (Jacquish 1989), a copy of which is provided to the Department of Ecology on publication. The AIRDOSE-EPA (Clean Air Act Code) computer code was used by PNL to develop the offsite dose data.

Radiological airborne emissions for 1988 from the proposed project site (400 Area) for calendar year 1988 were as follows:
$90 \mathrm{Sr}$
$2.1 \mathrm{E}-05 \mathrm{Ci}$
131 I
$1.0 \mathrm{E}-05 \mathrm{Ci}$
${ }^{41} \mathrm{Ar}$
$3.7 \mathrm{E}+01 \mathrm{Ci}$

These radionuclides combine for an effective dose equivalent (whole body dose) to the maximally exposed offsite individual of $2 \times 10^{-4} \mathrm{mR}$. The same report states that the effective dose equivalent to the maximally exposed offsite individual from all Hanford Site operations air emissions is $0.3 \mathrm{mR}$. Thus, current air quality at the proposed project site is responsible for less than $0.1 \%$ of the total Hanford Site dose to the maximally exposed offsite individual.

These doses can be compared to regulatory limits set by WAC 402-80-50 and WAC 173-480-040. The cited regulations set a whole body dose limit to the maximally exposed offsite individual of $25 \mathrm{mR}$ per year. The average dose to the maximally exposed offsite individual from 400 Area airborne emissions in 1988 , is less than $0.001 \%$ of the regulatory limit. 


\subsection{ANALYSIS OF THE PROPOSED SOURCE ON AMBIENT AIR QUALITY}

Again, radionuclides are the only regulated pollutants of concern projected to be emitted by the proposed source in significant quantities, as significant is defined by PSD regulations. Therefore, the analys is of the impact of the emissions from the proposed source on ambient air quality has been limited to impacts of projected ambient radionuclide concentrations.

\subsection{MODEL DESCRIPTION}

The AIRDOSE-EPA (Clean Air Act Code) computer code was used to calculate the dose from RPSF to the maximally exposed offsite individual.

Meteorological data input to the AIRDOSE-EPA code include mixing height, rainfall rate, average air temperature, vertical temperature gradient, wind direction frequency, wind speed, and atmospheric stability. This information was obtained from the data base compiled by the Hanford Meteorological Station (HMS). The HMS data on airspeed, direction, and temperature are collected at a $124.9-\mathrm{m}(410-\mathrm{ft})$ tower located on the Hanford Site between the 200 East and 200 West Areas, and at a second tower at the 400 Area. Wind speed and direction are based on hourly data collected at the 400 Area meteorological tower 10-m (32.8-ft) level during the years 1983 to 1987 . Atmospheric stability was estimated from the temperature gradient between the $9.1-\mathrm{m}$ $(30-\mathrm{ft})$ and $60.9-\mathrm{m}(200-\mathrm{ft})$ levels at the HMS for the same period using standard methods of the US Nuclear Regulatory Commission. Air temperature and mixing height are also 5-yr averages of hourly data. Temperature is measured at the tower $61-\mathrm{m}(200-\mathrm{ft})$ level, and mixing height data are collected by onsite acoustic sounders.

Joint frequency data, as reported by the HMS, are modified for input into AIRDOSE-EPA by conversion to true average and reciprocal average wind speeds for each direction and stability class. The meteorological data are then used to calculate $x / Q$ values for each radionuclide, which are also a function of radiological half-life and dry deposition velocity. For purposes of this calculation, deposition velocities are assigned as follows: $1.0 \times 10^{-3} \mathrm{~m} / \mathrm{s}$ for all particulate materials, $1.0 \times 10^{-2} \mathrm{~m} / \mathrm{s}$ for iodine isotopes, and zero for all gases.

Source Terms: Projected annual releases from RPSF as presented in Table 2-1.

Release Height: The FCFS/RPSF stack height is $36 \mathrm{~m}(117 \mathrm{ft})$.

Inhalation Rate: $8,500 \mathrm{~m}^{3} / \mathrm{yr}\left(300,173 \mathrm{ft}^{3} / \mathrm{yr}\right)$.

Maximally Exposed Individual: Doses were estimated for an individual living $8.7 \mathrm{~km}(5.4 \mathrm{mi})$ south of the 427 Building.

Meteorology: The HMS data and onsite meteorological data, as discussed above. 


\subsection{RESULTS OF MODELING ANALYSIS}

As stated in Section 7.0, total 1988 airborne radiological emissions from the Hanford Site resulted in $0.3 \mathrm{mR}$ whole body dose to the maximally exposed offsite individual. Table 2-5 shows that the projected doses from RPSF controlled airborne radiological emissions to the maximally exposed offsite individual are $2.2 \times 10^{-3} \mathrm{mR}$ (radon) to the whole body. The airborne radiological emissions from RPSF will constitute $7.3 \times 10^{-3}$ of the whole body dose to the maximally exposed offsite individual resulting from airborne radiological emissions from all Hanford Site operations, based on 1988 data.

The natural background radiation dose for the Tri-Cities area of Washington State is estimated to be $300 \mathrm{mR}$. The projected dose from the RPSF would be $7.3 \times 10^{-6}$ of natural ambient radiation.

Table 2-5. Offsite Dose Estimates for an Individual Receiving

Maximum Exposure to Airborne Radiological Emissions from Radioisotope Power Systems Facility (mR).

Whole body

$\begin{array}{lcccccr}220 & \begin{array}{c}\text { Other } \\ \text { nuclides }\end{array} & \text { Total } & \begin{array}{c}220 \mathrm{Rn}+\mathrm{D} \\ \text { (pulmonary lung) }\end{array} & \begin{array}{c}\text { Other nuclides } \\ \text { (bone surface) }\end{array} & \text { Total } \\ \overline{2.2} \mathrm{E}-03 & 1.4 \mathrm{E}-14 & 2.2 \mathrm{E}-03 & 8.9 \mathrm{E}-03 & 1.8 \mathrm{E}-13 & 8.9 \mathrm{E}-03\end{array}$

\subsection{DEMONSTRATE THAT PROPOSED EMISSIONS WILL NOT CAUSE A VIOLATION OF STATE OR NATIONAL AMBIENT AIR QUALITY STANDARDS.}

Both WAC 402-80-50 and WAC 173-480-040 state:

The WDOE ambient standard requires that emissions of radionuclides to the air shall not cause a dose equivalent of more than $25 \mathrm{mrem} / \mathrm{y}$ to the whole body or $75 \mathrm{mrem} / \mathrm{y}$ to a critical organ of any member of the public.

National ambient air quality standards for U.S. Department of Energy (DOE) facilities are stated in 40 CFR 61.92 as follows:

Emissions of radionuclides to air from DOE facilities shall not exceed. those amounts that cause a dose equivalent of $25 \mathrm{mrem} / \mathrm{y}$ to the whole body or $75 \mathrm{mrem} / \mathrm{y}$ to the critical organ of any member of the public.

If the projected airborne radionuclide doses from RPSF, as 1 isted in Table 2-6, to the maximally exposed offsite individual are added to the 
historic releases for 1988 , it is clear that RPSF emissions will not cause a violation of either state or federal standards.

\subsection{DEMONSTRATE THAT PROPOSED EMISSIONS WILL NOT CAUSE AN EXCURSION OVER PSD INCREMENTS FOR PART ICULATE MATTER AND SULFUR DIOXIDE}

No sulfur dioxide will be emitted by the RPSF; therefore the PSD sulfur dioxide increments are not applicable.

Because the proposed project will not meet significant emission levels for particulate matter as defined by 40 CFR 52.21, no air quality impact analyses are required for particulate matter.

\subsection{DEMONSTRATE THAT PROPOSED EMISSIONS WILL NOT IMPAIR VISIBILITY IN A CLASS I AREA OR OTHER SENSITIVE AREAS}

Because the proposed source will not be constructed within $10 \mathrm{~km}$ ( $6.2 \mathrm{mi})$ of a Class I Area, 40 CFR 52.21 states that demonstrations of visibility impact are not required.

\subsection{DISCUSS THE PROPOSED PROJECT'S EFFECTS ON RESIDENTIAL OR COMMERCIAL GROWTH, VEHICULAR TRAFFIC, SOILS, VEGETATION, ACID DEPOSITION AND ANY OTHER AIR QUALITY RELATED VALUES.}

The proposed project will have no impact on residential or commercial growth or vehicular traffic because the proposed project will be located on the Hanford Site, a Federal Government public exclusion area.

The following, taken from the Hanford Site Environmental Report for Calendar Year 1988 (Jacquish 1989) describes the Hanford Site area soil and vegetation monitoring program and states the results of that program for 1988.

Surface soil and rangeland vegetation samples were collected at a number of locations during 1988, both on and off the Hanford Site. The purpose of sampling was to detect the possible build-up of radionuclides from the deposition of airborne effluents released from Hanford facilities. Samples were collected at nonagricultural, relatively undisturbed sites so that natural deposition and build-up processes would be represented. An assessment of radionuclide contributions from Hanford operations was made by comparing results from samples collected 1) on Site with those collected off Site, 2) around the site perimeter with those collected at distant locations, and 3 ) downwind (primarily east and south of the Site) with those collected from generally upwind and distant locations. In addition, results obtained from each location in 1988 were compared 
to results obtained from the same location in previous years. Evaluations of 1988 results provided no indication of trends or increases in the concentrations of radionuclides in the offsite environment that could be attributed to Hanford operations.

A detailed description of the results of the this study can be found in Chapter 4.5 of the publication cited.

In light of the PNL study results cited above, an increase of emissions (radon) on the order of magnitude being discussed $\left(10^{-3}\right)$ indicates that the proposed project will have no measurable effect on soils or vegetation in the area. 


\section{REFERENCES}

Burchsted et a1. 1976, Nuclear Air Cleaning Handbook--Design, Construction, and Testing of High-Efficiency Air Cleaning Systems for Nuclear Application, C.A. Burchsted, J.E. Kahn, and A.B. Fuller, ERDA-76-21, Oak Ridge National Laboratory, Oak Ridge, Tennessee.

Jacquish, R.E. 1989, Hanford Site Environmental Report for Calendar Year 1988, PṆL-6825, Pacific Northwest Laboratory, Richland, Washington.

McDowell et al. 1976, Penetration of HEPA Filters by Alpha Recoil Aerosols, W.J. McDowe11, and F.G. Seeley (Oak Ridge National Laboratory), and M. T. Ryan (University of Lowe11, Massachusetts), 14th ERDA Air Cleaning Conference, Sun Valley, Idaho, August 11-13, 1976.

Moore, E.B. and H.T. Fullam 1984, Control Technology for Radioactive Emissions to the Atmosphere at U.S. Department of Energy Facilities, PNL-4621-Final, Pacific Northwest Laboratory, Richland, Washington.

Zippler, D.B. 1974, "Evaluation of Multistage Filtration to Reduce Sand Filter Exhaust Activity," Proceedings of the 13th AEC Nuclear Air Cleaning Conference, Vol. 1, San Francisco, California, March 1975, pp. 609-619. 


\section{Prevention of Significant Deterioration \\ New Source Review for \\ Fuel Assembly Area}

\subsection{PROJECT LOCATION}

The Fuel Assembly Area (FAA) will be located in Building 4862 of the Fuels and Materials Examination Facility (FMEF) (Figure 3). Figure 13 depicts the layout of the FAA within Building 4862 .

\subsection{PROCESS DESCRIPTION}

The FAA will fabricate and store enriched uranium oxide driver fuel and neptunium oxide target pins for the Fast Flux Test Facility (FFTF). At a later date, mixed uranium plutonium oxide (MOX) fuel may be processed within FAA. The production of MOX fuel will use basically the same process as the enriched uranium, which will be the initial fuel processed. The following process description refers only to enriched uranium, though it is applicable to MOX.

A process flow diagram for the production of the enriched uranium oxide driver fuel is shown in Figure 14. A process flow diagram for the neptunium target pin fabrication and storage is shown in Figure 15.

\section{Enriched Uranium Oxide Driver Fuel Fabrication}

Shipments of powder and pellets will be received in standard shipping containers. The containers will be unloaded and transferred to the high bay area (room 101) and stored until they can be unloaded. From room 101, the containers will be transferred to rooms 104, 107, or 109 for unloading.

Inside the container will be a sealed fuel shipping canister, which contains the powder or pellets. The fuel shipping canisters will be removed from the containers. Within each canister will be up to four cans, each containing approximately $1 \mathrm{~kg}(2.2 \mathrm{lb})$ fissile powder, or two cans, each containing approximately $2.5 \mathrm{~kg}(5.5 \mathrm{lb})$ fissile pellets. The cans will be removed, surveyed, cleaned, and processed through nondestructive assay. The cans will then be transferred to room 110 for storage.

The first major process step will be powder conditioning and pressing. Within the pressing enclosures in room 110, powder and binder will be weighed and blended; blended powder will be preslugged; slugs will be granulated; and granules and binder will be weighed, blended, and repackaged in cans for storage or transfer to the next operation. The granule-binder mixture will then be pelletized and transferred to the sintering/debind enclosure. Three single-cavity presses will be available for performing the preslugging and pelletizing. 


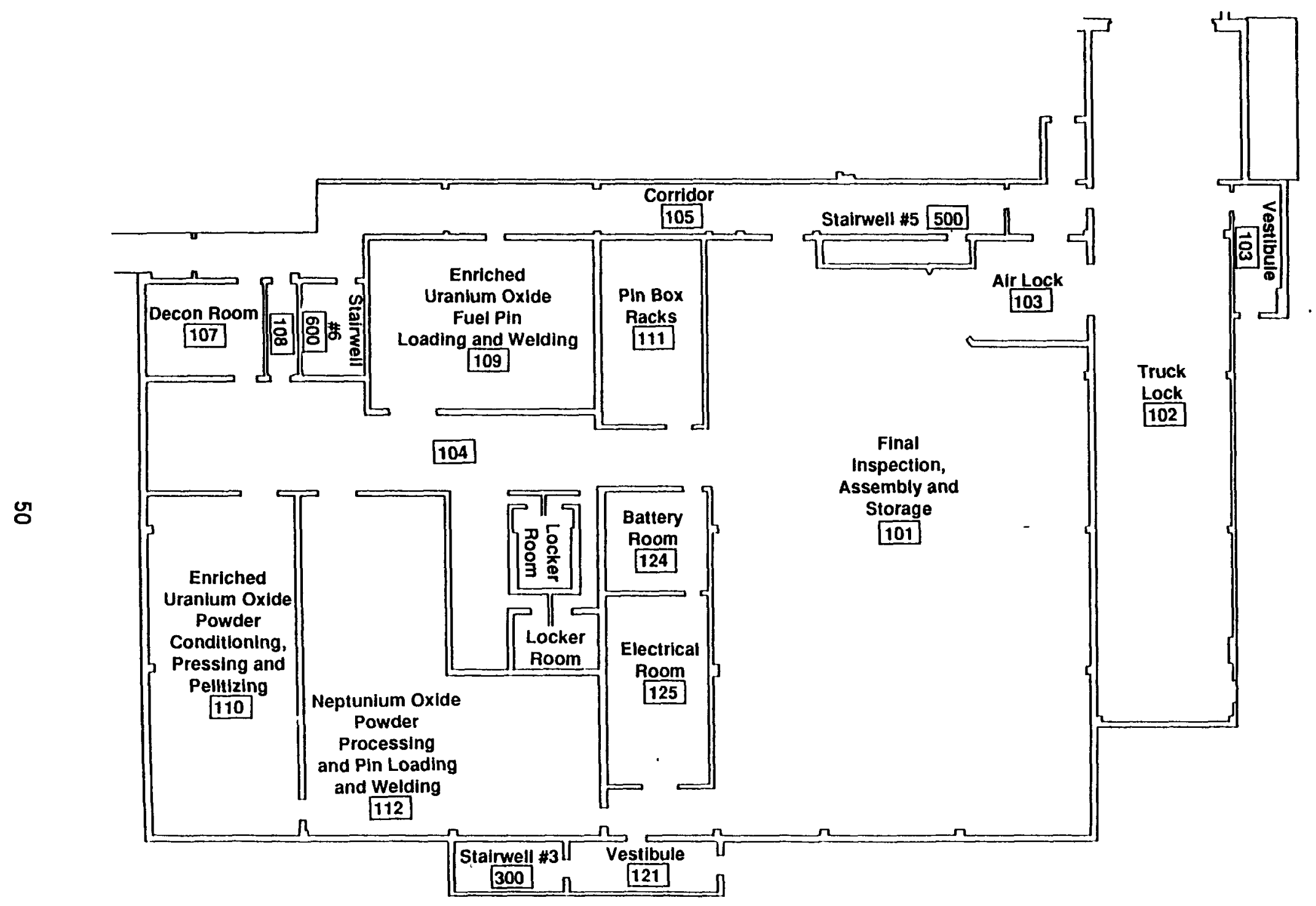

Figure 13. Fuel Assembly Area Floor Plan. 


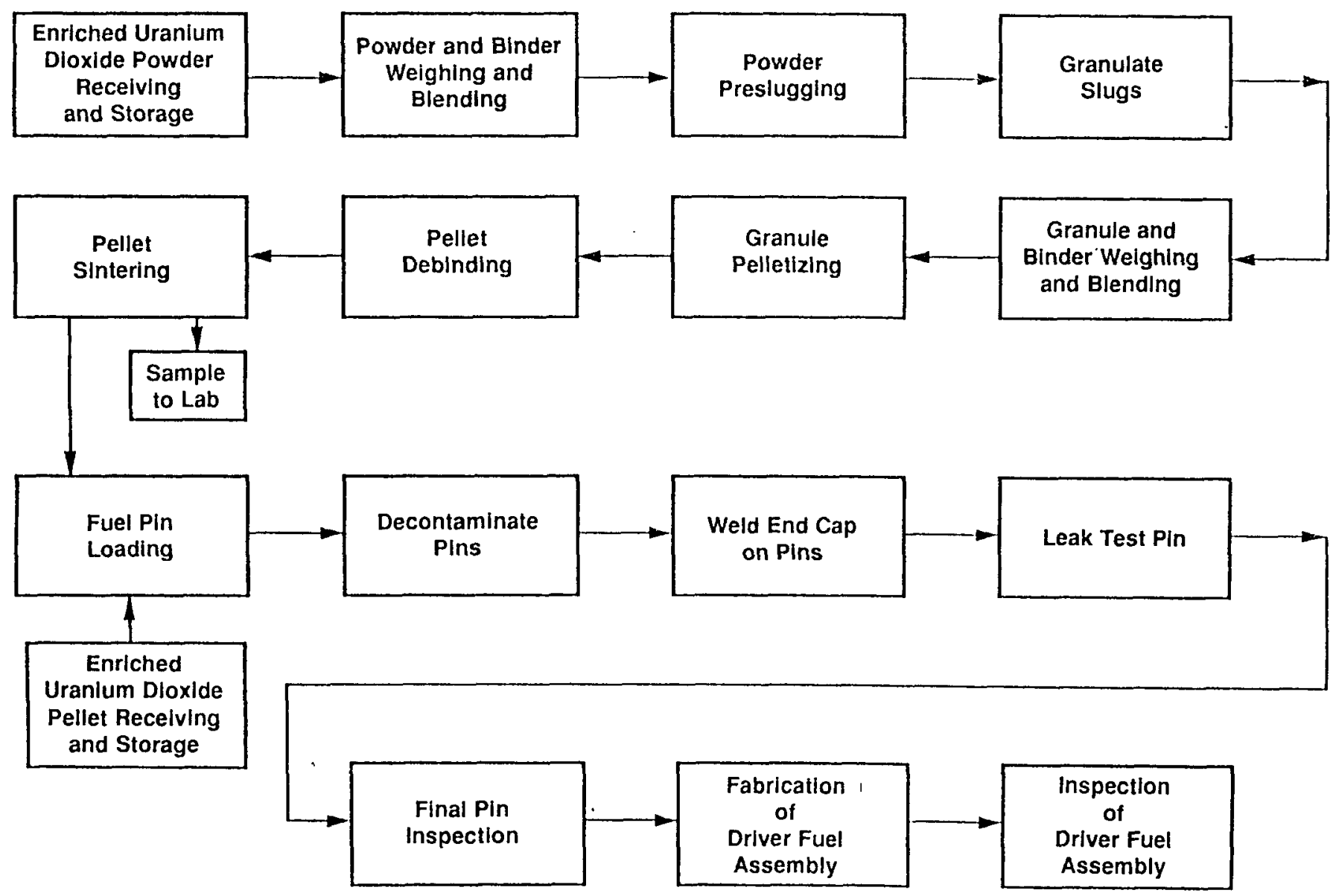

Figure 14. Overall Process Flow Diagram for Enriched Uranium Oxide Driver Fuel Fabrication. 

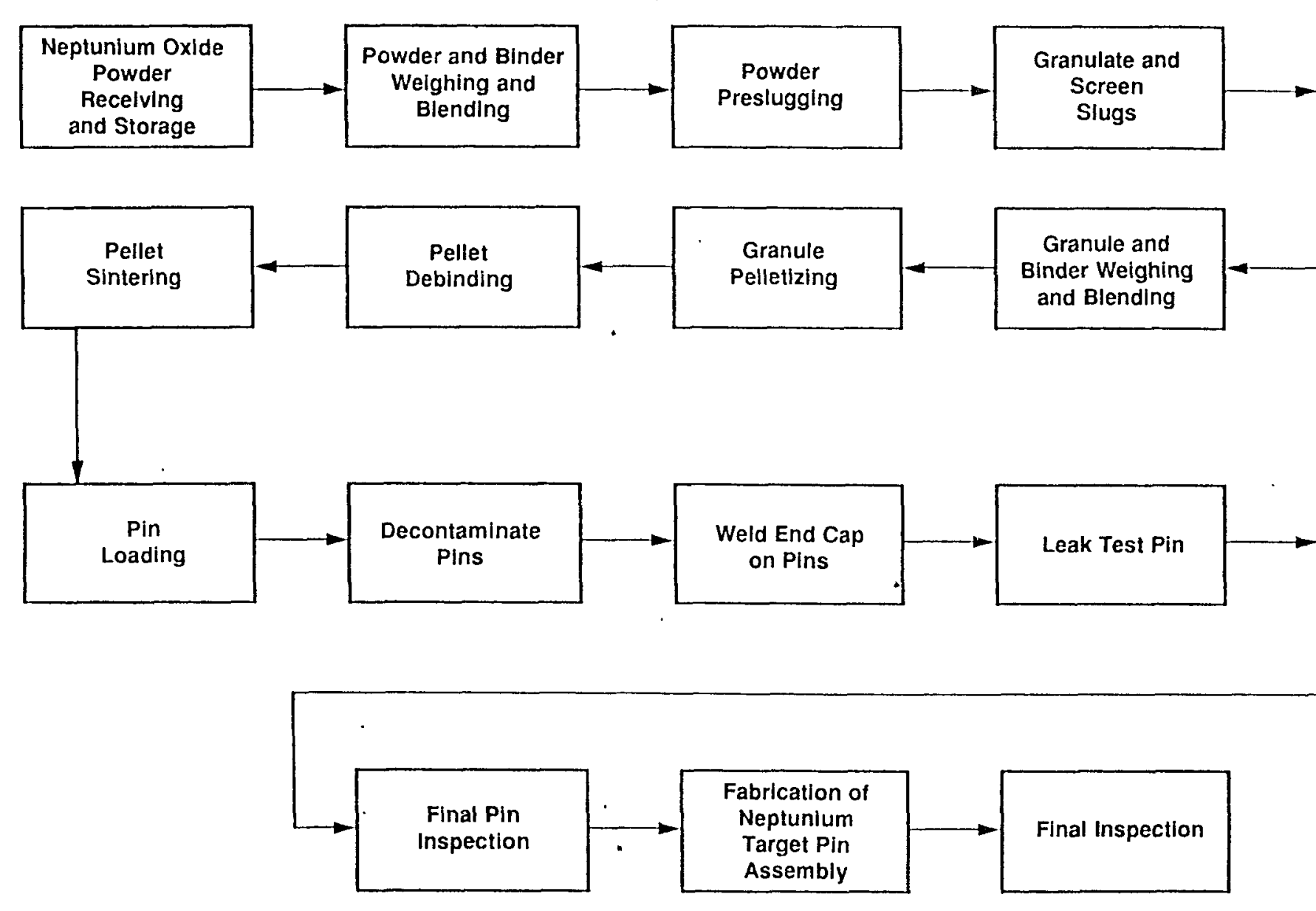

78908035.13

Figure 15. Overall Process Flow Diagram for Neptunium Target Pin Fabrication in the Fuel Assembly Area. 
Within the sintering/debind enclosure in room 110 , the pellets will be loaded into a furnace for debinding and will then be loaded into a second furnace for sintering. Once the pellets have been removed from the sintering furnace, some of the pellets will be sent to a laboratory for analysis. The remaining pellets will be repackaged in cans and returned to storage in room 110 .

Pellets will be transferred from storage to the fuel pin loading glovebox in room 109. At this station, the fuel pellets will be visually inspected, the fuel annulus verified, the fuel column assembled, and the fuel column and other pin internal components loaded into the fuel cladding. After loading, the top end of the fuel pin cladding will be cleaned to reduce gross contamination and the end of the cladding will be sealed and surveyed. The loaded pins will then be placed in a pin box for transfer to room 107 . In room 107, the pin will undergo further decontamination. The decontaminated pins will be resealed, placed into the pin box, and returned to room 109 for end cap final closure weld.

There the pins will be placed in an evacuation chamber and the temporary plug will be removed. The chamber will be evacuated and backfilled until all of the air has been replaced with helium fill-gas. The chamber will then be opened to the weld enclosure and the tag gas capsule and top end cap will be inserted and the top end cap welded to the cladding. The pins will then be removed from the welding enclosure and taken to the leak test enclosure, also located in room 109. The pins will then either be transferred to room 111 for storage or processed through final inspection.

Final inspection operations will be performed in room 101, and will include tag gas rupture, $X$-radiography, fuel enrichment verification, pin workmanship, final visual inspection, end cap drill, and wire wrap.

When pins are ready for assembly into the driver fuel, they will be taken to the final assembly table in room 101 . Here, the individual pins will be assembled into pin bundles (217 pins/bundle). The pin bundles will then be inspected. After inspection, the pin bundles will be transferred to the assembly pit where the direct-handling subassembly will be lowered over the pin bundle. The pin bundle will then be returned to the assembly table and the duct welded to the shield inlet assembly. The weld will be examined and a final wipe of the assembly will be taken. Final inspection of the driver fuel assembly will include an air flow test and weight and center of gravity measurements. After all standard inspection and measurements are performed, the assembly will be returned to the storage pit or prepared for shipment.

\section{Neptunium Oxide Target Pin Fabrication}

The neptunium oxide will be received and stored within the Target Pin Fabrication Line in. room 112. If necessary, the powder will be milled and screened to meet feed powder specifications. The powder will be mixed with binder in a blender and will then be preslugged in a cold press. The slugs will be granulated and screened. The resulting granules will be mixed with binder in a blender, and will then be pressed into pellets. The pellets 
will be transferred to a furnace for debinding and then to a second furnace for sintering. After sintering, the pellets will be inspected for conformance to specifications. The pellets conforming with specifications will be stored temporarily before being sent to target pin fabrication. Pellets not meeting specifications will be ground into powder to be used to make new pellets.

From temporary storage, cans of pellets will be transferred to the pin loading enclosure of room 112. The pellets will be removed from the cans and loaded into the pin. The pin will then be decontaminated at the loading station. After decontamination has been completed, the pin will be transported to the welding station in room 112 for the final closure weld. The assembled pins will be leak tested before storage. Final operations on the pins will be performed in room 101, and will include tag gas rupture, weld $X$-radiography, inspection, pin workmanship, and final visual inspection.

When pins are ready for fabrication into neptunium target pin assemblies, they will be taken to the target final assembly station in room 101 . Here, the individual pins will be inserted into pin bundles. The assembled neptunium pin bundles will then be stored in room 101 storage pit.

\subsection{SOURCES OF EMISSIONS}

The FAA will be provided with ventilation Zones I, II, III, IV, and airlocks, as required, for zone separation in high-traffic access areas. Areas denoted Zone I will contain the unencapsulated radioactive materials being processed and will be separated from surrounding ventilation Zone II areas. Ventilation Zone II areas will process encapsulated radioactive materials and will bound Zone I. Ventilation Zone III will comprise "a" and "b" areas. Ventilation Zone IIIa areas will bound Zone II and will be those areas in which encapsulated radioactive materials are handled. Ventilation Zone IIIb areas will be buffer zones and will not contain radioactive materials.

There will be a negative pressure gradient from Zone III to I so that any contaminants will flow into Zone $I$ and through the facility emissions abatement systems. All Zone I air flows out the FAA stack. Figure 16 depicts FAA cell air flow and indicates points of emission to the air.

\section{Zone I}

Gloveboxes in rooms 109,110 , and 112 and open-face hoods in rooms 107 , 109 , and 112 will be part of the Zone I ventilation system. These enclosures will be used in the processing of uranium dioxide and neptunium oxide powder into pellets and in the encapsulation of these pellets into pins, as described in Section 2.0, above. Releases of radioactive materials to the ventilation system will occur in Zone I. 


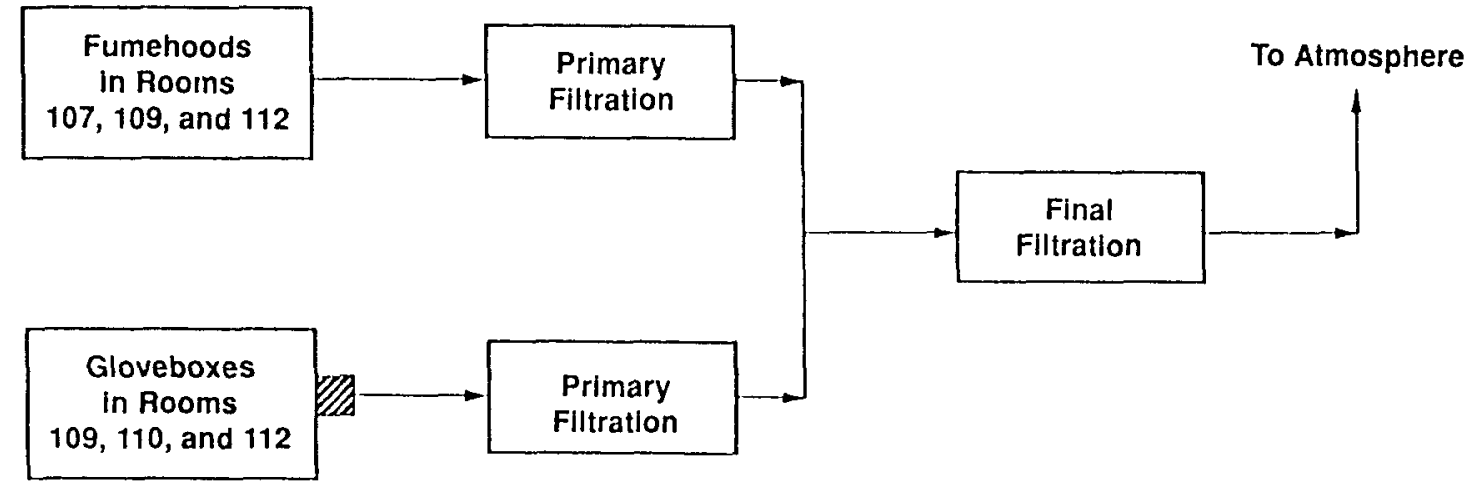

G

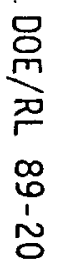

WII Non-Testable HEPA - One Filter is Located on Outlet of Each Glovebox.

78908035.14

Figure 16. Fuel Assembly Area Zone I Exhaust Flow Diagram. 


\section{Zone II}

Rooms $104,107,109,110$, and 112 will be part of the Zone II ventilation system. Releases of radioactive materials to the Zone II ventilation system are not likely to occur because the processing of unencapsulated radioactive materials will be performed only in Zone I areas and because of the pressure differential between Zone II to Zone I.

\section{Zone III}

Rooms 101, 274, and 279 and shall be Zone IIIa. Rooms 271, 276, 277, and 278 and corridors 105 and 272 shall be Zone IIIb. Releases of radioactive materials to the Zone III ventilation system are highly unlikely because they will not contain any unencapsulated radioactive materials.

\section{Zone IV}

Rooms 124, 125, and 102 will be at atmospheric pressure and will thus be considered part of Zone IV. Releases of radioactive materials will not take place in Zone IV because no radioactive materials will be handled in those areas.

\subsection{DESIGN AND OPERATING PARAMETERS}

\subsection{HOURS OF OPERATION}

The FAA is intended to operate $8 \mathrm{~h} / \mathrm{d}, 5 \mathrm{~d} / \mathrm{wk}, 44 \mathrm{wk} / \mathrm{yr}$ (not including maintenance downtime.)

\subsection{NORMAL AND MAXIMUM PRODUCTION RATES}

Production rates are stated in terms of fuel pins. The normal production rate is approximately 11,000 fuel pins per year. The theoretical "maximum" production rate is approximately 13,000 fuel pins per year. (The maximum production rate was developed assuming no need to shut down any plant process equipment for maintenance or any other reason whatsoever for a period of 1 $y r$.

\subsection{FUEL REQUIREMENTS}

The fuel to be used by the FAA is electricity. The projected average annual usage is 175 kVA. 


\subsection{RAW MATERIAL REQUIREMENTS}

At a production rate of approximately 11,000 enriched uranium oxide fuel pins per year, and approximately $575^{237} \mathrm{~Np}$ pins per year, the FAA will use the following materials:

- Enriched $\mathrm{UO}_{2}$ powder $\left(\mathrm{EUO}_{2}\right): 1850 \mathrm{~kg}(4,078 \mathrm{lb})$

- $237 \mathrm{~Np}$ oxide powder: $115 \mathrm{~kg}(254 \mathrm{lb})$

- Alcohol: $38 \mathrm{~L} / \mathrm{yr}(10 \mathrm{gal} / \mathrm{yr})$ or less: used as a solvent

- Butyl sterate: approximately $50 \mathrm{~kg} / \mathrm{yr}(110 \mathrm{lb} / \mathrm{yr})$ : used as a fuel binder

- Sterotex: approximately $50 \mathrm{~kg} / \mathrm{yr}(110 \mathrm{lb} / \mathrm{yr})$ : used as a fuel binder

o Zinc stearate: approximately $50 \mathrm{~kg} / \mathrm{yr}(110 \mathrm{lb} / \mathrm{yr})$ : used as a fuel binder

- Carbowax: approximately $50 \mathrm{~kg} / \mathrm{yr}(110 \mathrm{lb} / \mathrm{yr})$ : used as a fue 1 binder

\subsection{EMISSIONS CONTROL SYSTEM}

Because the radioactive airborne emissions from FAA will consist primarily of particulate matter generated during the processing of $\mathrm{EUO}_{2}$ and $237 \mathrm{~Np}$ oxide powders (Section 2.1), the emissions control system must be capable of containing micrometer-and submicrometer-size particles.

As discussed in Section 2.1, the FAA operations are provided with ventilation Zones I, II, and III with negative pressure gradient from Zone III to Zone I, to provide maximum confinement of radioactive contamination. All powder handling operations will take place in Zone I gloveboxes. Zone I gloveboxes shall be operated at -0.55 to $-0.75 \mathrm{in}$. WG pressure relative to outside atmosphere. Zone II shall be operated at -0.20 to $-0.30 \mathrm{in}$. WG pressure relative to outside atmosphere. Zone IIla radiological operating and equipment areas shall be operated at -0.05 to -0.15 in. WG pressure relative to outside atmosphere. Zone IIIb shall be operated at -0.05 to $-0.10 \mathrm{in}$. WG pressure relative to outside atmosphere, Zone IV.

Zone I ventilation areas draw air from the surrounding Zone II rooms. Figure 17 shows FAA Zone I exhaust flow. Zone II ventilation areas use a recirculated air atmosphere. Special sealed structures and structural penetrations are implemented to separate Zone I and Zone II areas. Zone I and Zone II exhausts are vented to separate primary filtration steps before being combined and routed to final filtration and subsequentiy discharged to 
the atmosphere. Some Zone III exhaust is routed directly to Zone II areas to supply ventilation air to Zone II. The remainder of Zone III exhaust is ultimately routed along with other plant exhausts to a single final filtration step and discharged to the atmosphere.

The exhaust from the FAA process operations will be provided with both primary and final particulate control measures as described above. This allows for high-efficiency removal and provides system redundancy in the event of a failure of one of the emission control units. In addition, the gloveboxes (Zone I) are equipped with nontestable HEPA filters on both the inlet and outlet flows to minimize the radionuclide contamination of the connected atmosphere control systems. The fumehoods in rooms 107, 109, and 112 will not be equipped with non-testable HEPAs because the distance to the testable HEPAs is relatively short.

After primary treatment, all the exhaust from FAA operations is combined and routed to a final filtration step before discharge through the main building stack. Final, high-efficiency particulate filtration before discharge of the radionuclide contaminated gases to the atmosphere is a nuclear industry standard. Generally, two-stage filtration is used for this purpose. Presently employed final filtration techniques in the nuclear industry include combination prefilter and HEPAs, deep-bed glass-fiber filters, and deep-bed sand filters. The best available radionuclide control technology (BARCT) assessment developed for this proposed project demonstrated that the prefilter and HEPA system provides the highest degree of removal efficiency.

\subsection{EMISSIONS - TYPE AND QUANTITY}

\subsection{REPRESENTATIVE EMISSIONS FROM THE EXISTING SOURCE}

The FAA, as part of the FMEF complex, was designed and constructed to produce production reactor fuels for the Liquid Metal Reactor program. The current FAA building was to house the secure automated fabrication (SAF) fuel production line. The SAF mission was cancelled in 1986, with the facility $96 \%$ complete. No activity or radioactive materials have been introduced into the FAA facility. The only "emissions" from the FAA stack have been from the HVAC system functioning to heat or cool the facility. The average temperature at the stack is $25.6^{\circ} \mathrm{C}\left(78^{\circ} \mathrm{F}\right)$. The average stack flow rate is $199.6 \mathrm{~m}^{3} / \mathrm{min}\left(7,050 \mathrm{ft}^{3} / \mathrm{min}\right)$. 


\subsection{PROJECTED ACTUAL CONTROLLED EMISSIONS}

The projected actual controlled emission rates of particulate radionuclides for the FAA were calculated based on an annual MOX throughput of $100 \mathrm{~kg}(220 \mathrm{lb})$, an annual enriched uranium oxide throughput of $1850 \mathrm{~kg}$ $(4,078 \mathrm{lb})(220 \mathrm{lb})$, an annual $\mathrm{Np}-237$ oxide throughput of $115 \mathrm{~kg}$ (253.5 1b) and using a release adjustment factor (RAF) of $2.5 \times 10^{-10}$. Though the MOX fuel and enriched uranium fuel will not be processed simultaneously, complete annual campaigns for both fuels were used as source terms in order to permit the changeover from one fuel to the other.

The RAF assumes that $1 \%$ (the release factor) of the throughput material will become entrained in the cell atmosphere and pass through the ventilation system. (This is an extremely conservative assumption because there are non-testable HEPA filters between the gloveboxes and the ventilation system. The HEPAs are $99.97 \%$ efficient upon installation. Therefore, for $1 \%$ of the entire throughput to become entrained in the ventilation system, over $100 \%$ of the entire throughput would have to be released.) The ventilation system is assumed to contain three HEPA filters in series, which is equivalent to a transmission factor of $2.5 \times 10^{-8}$. It is also understood (McDowell et al. 1976) that where the aerosols are realistic in terms of what comes out of the facility, the recoil effect is not proven. In light of the possibility of the recoil effect, monitoring, appropriate filter changeouts, and other administrative controls will be implemented to ensure filter system integrity. (As noted above, the gloveboxes actually have an additional HEPA filter; however, because this filter is non-testable and the removal efficiency cannot be verified during operation, no credit is taken for these filters in the dose calculations.) The RAF is the product of the release factor and the transmission factor. The actual projected controlled radioactive airborne particulate emissions releases for the FAA are shown in Table 3-1.

Table 3-1. Controlled Particle Radionuclide Emission Rates

(Actual) for Fuel Assembly Area (Emissions at Stack).

\section{Nuclide}

$$
\begin{aligned}
& 232 \mathrm{U} \\
& 234 \mathrm{U} \\
& 235 \mathrm{U} \\
& 236 \mathrm{U} \\
& 238 \mathrm{U} \\
& 236 \mathrm{Pu} \\
& 238 \mathrm{Pu} \\
& 239 \mathrm{Pu} \\
& 240 \mathrm{Pu} \\
& 241 \mathrm{Pu} \\
& 242 \mathrm{Pu} \\
& 237 \mathrm{Pu}
\end{aligned}
$$

Emission rate $(\mathrm{C} i / \mathrm{yr})$

$4.36 \mathrm{E}-09$

$3.06 \mathrm{E}-08$

$3.52 \mathrm{E}-10$

$6.33 E-09$

$5.32 \mathrm{E}-11$

$8.76 \mathrm{E}-12$

$5.65 \mathrm{E}-08$

$2.79 \mathrm{E}-07$

2.08 E-07

7.93 E-06

8.64 E-11

$1.79 \mathrm{E}-08$ 
The controlled emission rates of gaseous radionuclides $(\angle 20 R n)$ for the FAA were conservatively calculated from the total amount of radon being generated within the fuel material being handled. (In reality, a large fraction of the $220 \mathrm{Rn}$ will decay before it leaves the fuel because $220 \mathrm{Rn}$ has a half-life of only $55.6 \mathrm{~s}$.) The enpriched uranium fuel alone was used to determine $220 \mathrm{Rn}$ releases because $232 \mathrm{U}$ represents the bounding radiological source term for radon.

Because of the short half-life of radon, decay in transit through the exhaust ductwork to the point of release is considerable. (The decay of $220 \mathrm{Rn}$ in the ductwork follows the ordinary exponential decay law.) The emission rate of $220 \mathrm{Rn}$, therefore, is equal to the initial $220 \mathrm{Rn}$ activity multiplied by the decay factor to take into account decay during transit. The decay factor is determined by the following formula:

$$
\text { Decay Factor }=\mathrm{e}^{(-\mathrm{t} * \mathrm{~L}[220])}=0.0672
$$

where: $-t=$ transit time in ducts $(3.61 \mathrm{~min})$

$$
\begin{aligned}
& L^{*}=\text { decay constant (In2/half } 1 \text { ife of specific radionuclide) } \\
& \text { e }=2.7183
\end{aligned}
$$

The amount of $220 \mathrm{Rn}$ released from the facility depends on the initial radon activity (which is determined by the $232 \mathrm{U}$ impurity concentration, the preprocessing decay time of $232 \mathrm{U}$, and the residence time of $220 \mathrm{Rn}$ inside the facility before being emitted) multiplied by the above described decay factor. The specific maximum release rate input data for these factors is listed in Table 3-2. The resulting emissions are listed in Table 3-3.

Table 3-2. Input for 220 Rn Emissions (Actual Calculations for Fuel Assembly Area).

$\begin{array}{ll}\text { Facility } U \text { inventory: } & 19.0 \mathrm{~kg} \mathrm{U}(41.8 \mathrm{lb}) \\ \text { Initial } 232 U \text { impurity: } & 300.0 \mathrm{p} / \mathrm{B} \\ \text { Pre-processing decay time: } & 3 \text { months } \\ \text { Facility residence time: } & 1 \text { weeks }\end{array}$

Table 3-3. Controlled Radon Emission Rate (Actual) for Fuel Assembly Area.

$\frac{\text { Nuclide }}{220 \mathrm{Rn}}$ $\frac{\mathrm{Ci} / \mathrm{yr}}{280}$

\subsection{PROJECTED POTENTIAL CONTROLLED EMISSIONS}

The following discussion and analysis provide releases from theoretical production rates. The FAA is being designed for a production rate of $11,000 \mathrm{pins} / \mathrm{yr}$. 
Projected potential controlled emission rates are the emission rates that would result from operation of the facility at maximum capacity $24 \mathrm{~h} / \mathrm{d}, 365$ $\mathrm{d} / \mathrm{yr}$. The projected potential controlled emission rates for the FAA have been calculated based on the data developed in sections $3.1,3.2$, and 4.2. To perform these calculations, the assumption was made that a linear relationship exists between the amount of throughput and the amount of emissions.

The projected potential controlled emission rate has been calculated from the controlled radionuclide emission rates, 1 isted in Tables 3-1 and 3-3, using the following formula:

$(8,760 / 1,760)(13,000 / 11,000)($ controlled radionuclide emission rate $)=$ projected potential controlled emission rate.

The factor $8,760 / 1,760$ in the above equation adjusts the controlled radionuclide emission rates to $24 \mathrm{~h} / \mathrm{d}$ and $7 \mathrm{~d} / \mathrm{wk}$ operation. The controlled radionuclide emission rates are based on operation of the facility $8 \mathrm{~h} / \mathrm{d}$ and $5 \mathrm{~d} / \mathrm{wk}$ for $44 \mathrm{wk}(1,760 \mathrm{hr}$ of operation). Operation of the facility $24 \mathrm{~h} / \mathrm{d}$ and $7 \mathrm{~d} / \mathrm{wk}$ for $1 \mathrm{yr}$ would result in $8,760 \mathrm{hr}$ of operation.

The factor $13,000 / 11,000$ in the above equation adjusts the production rate to maximum efficiency. The controlled radionuclide emission rates are based on a production rate of 11,000 fuel pins per year. The 11,000 fuel pins per year production rate would result from plant operations at expected efficiency, $8 \mathrm{~h} / \mathrm{d}$ and $5 \mathrm{~d} / \mathrm{wk}$. Operations at $100 \%$ efficiency, $8 \mathrm{~h} / \mathrm{d}$ and 5 $d / w k$, would result in a production rate of 13,000 fuel-pins per year.

The projected potential controliled particulate radionculide emission rates for the FAA are 1isted in Table 3-4. The projected potential controlled gaseous emissions rate for the FAA is shown in Table 3-5.

Table 3-4. Controlled Particle Radionuclide Emission Rates (Potential) Fuel Assembly Area (Emissions at Stack).

Nuclide

$$
\begin{aligned}
& 232 \mathrm{U} \\
& 234 \mathrm{U} \\
& 235 \mathrm{U} \\
& 236 \mathrm{U} \\
& 238 \mathrm{U} \\
& 236 \mathrm{Pu} \\
& 238 \mathrm{Pu} \\
& 239 \mathrm{Pu} \\
& 240 \mathrm{Pu} \\
& 241 \mathrm{Pu} \\
& 242 \mathrm{Pu} \\
& 237 \mathrm{~Np}
\end{aligned}
$$

Emission rate $(\mathrm{Ci} / \mathrm{yr})$

$2.56 E-08$

$1.80 \mathrm{E}-07$

$2.07 E-09$

$3.72 E-08$

$3.13 E-10$

$5.15 \mathrm{E}-11$

$3.32 \mathrm{E}-07$

1.64 E-06

$1.22 E-06$

4.66 E-05

$5.08 \mathrm{E}-10$

$1.05 E-07$ 
Table 3-5. Controlled Radon Emission Rate (Potential) for Fuel Assembly Area.
$\frac{\text { Nuclide }}{220 R n}$
$\frac{C i / y r}{1,650}$

\subsection{ANTICIPATED CONSTRUCTION SCHEDULE}

The following construction schedule is projected:

Start of design (conceptual)

Completion of design (definitive)

Start of major equipment procurement

Completion of major equipment procurement

Start of construction (pre-construction

activities)

Completion of construction
November 1988

July 1989

September 1989

February 1990

August 1989

January 1991

\subsection{A DEMONSTRATION OF BEST AVAILABLE CONTROL TECHNOLOGY (BACT) SELECTION}

Radionuclides are the only regulated pollutants of concern projected to be emitted by the proposed source in significant quantities as defined by PSD regulations. Therefore, the demonstration of BACT has been 1 imited to impacts of ambient radionuclide concentrations, or a demonstration of best available radionuclide control technology (BARCT).

A BARCT is defined by WAC $-480-60$ as follows:

Technology which will result in a radionuclide emission limitation based on the maximum degree of reduction for radionuclides which would be emitted from any proposed stationary source or modification of a source which the permitting authority on a case-by-case basis, taking into account energy, environmental, and economic impacts and other costs, determines is achievable for such source or modification through application of production processes or available methods, systems, and techniques. In no event shall application of best available radionuclide technology result in emissions of radionuclides which would exceed the ambient annual standard limitation specified in this chapter.

The selection of the emissions control system described in Section 3.5 is BARCT for the pollutants to be emitted by the FAA as supported by the following discussion. 


\subsection{CONTROL ALTERNATIVES}

Radionuclide emissions from the FAA will consist primarily of particulate matter generated during the processing and fabrication of the enriched uranium oxide or mixed oxide fuels and neptunium oxide target assemblies. Based on the handling operations that will be performed and the physical characteristics of the powder, suspended particulate matter is anticipated to be in the micrometer-and submicrometer-size range.

In order to identify all possible emission controls for this process, a nuclear and cross-industry survey for high-efficiency particulate matter controls was conducted (Appendix A). Therefore, devices capable of collecting only large-diameter particles are not included in the survey. All of the controls identified have been applied previously in radiochemical processing operations. High-efficiency particulate controls in the industrial sector are limited to HEPA filters, used for cleanroom applications, and packed fiber filters, for high-quality product gas filtration (essentially, high-efficiency mist eliminators [HEMEs]). Potential control devices identified in the surveys are presented in Table 3-6. Detailed process descriptions and evaluations are presented in Appendix B.

Table 3-6. Fuel Assembly Area Control Technology Survey Results.

\section{Particulate matter}

HEPA filter

Deep-bed sand filter

Deep-bed glass-fiber filter

High-efficiency mist eliminator

Prefilter
$99.97 \%$ for $0.3-\mu \mathrm{m}$ particles $99.95 \%$ for $0.3-\mu \mathrm{m}$ particles $99.9 \%$ for $0.3-\mu \mathrm{m}$ particles $99.5 \%$ for $1-\mu \mathrm{m}$ particles $85 \%(\max )$ for $0.3-\mu m$ particles

Of the potential particulate controls identified in Table 3-6, only the prefilter and HEPA can be applied to primary particulate control in this application.

In the nuclear industry, prefilters are generally used in combination with HEPAs to remove the larger particles in the exhaust stream, thus increasing the service life of the HEPAs. Extremely large units, such as the deep-bed sand and deep-bed fiber filters cannot be considered as primary filters because adequate floor space is not available. Although the HEME is relatively small (about $0.9 \mathrm{~m}[3 \mathrm{ft}]$ in length) it is significantly less effective than the HEPA in its removal of small particles, it requires additional plumbing (for possible filter cleaning with a waterwash), and it is normally not used for dry room offgas systems. Therefore, a combination prefilter/HEPA assembly is considered the only applicable particulate control 
alternative based on performance and operating/physical constraints for primary FAA exhaust treatment and is thus proposed as BARCT for this particular application. No further analys is of energy, environmental, or economic impacts is required because the control technology identified has been determined to be the technology that is both appropriate and that allows the lowest emission rate of radionuclides. Any other control technology would not provide a comparable low environmental impact, regardless of energy or economic impact. The BARCT analysis will therefore be limited to the final filtration processes only.

After primary treatment, all the exhaust from the FAA operations is combined and routed to a final filtration step before discharge through the FAA building stack. Final high-efficiency particle filtration before discharge of radionculide-contaminated gases to the atmosphere is a nuclear industry standard. Generally, two-stage filtration is used for this purpose. Presently employed final filtration techniques in the nuclear industry include combination prefilter and HEPAs, deep-bed glass-fiber filters, and deep-bed sand filters (Table 3-6). Deep-bed glass-fiber and sand filters are normally installed upstream of a final contact HEPA filter. Therefore, the alternative control systems for the final FAA exhaust that will be evaluated are the following:

Alternative 1 - deep-bed glass-fiber filter/one-stage HEPA

Alternative 2 - deep-bed sand filter/one-stage HEPA

Alternative 3 - two-stage HEPA.

The following discussion will present an evaluation of these final emission control alternatives based on environmental, energy, and economic impacts to demonstrate BARCT for the FAA emissions.

\subsection{ENVIRONMENTAL}

A11 of the three alternatives incorporate a HEPA filter as the secondstage control device. Studies have shown that the removal efficiency of a HEPA placed downstream of another high-efficiency particulate control device (such as a deep-bed sand filter or another HEPA) is lower than that of a single-stage HEPA (Zippler 1974). It is postulated that this is because of the extraction of the more readily collected particles in the initial filter (Moore and Fullam 1984). Sufficient data are not available to determine the effect that this would have on the overall removal efficiency of each control system. For the purposes of this analysis, it is assumed that the secondstage HEPA performs identically for each system. Therefore, the overall efficiency is directly related to the removal efficiency of the first stage unit. As shown in Table 3-6, alternative 3 (two-stage HEPA) would provide somewhat higher performance than alternatives 2 and 1 , respectively. Because ground-level radionuclide impacts are directly dependent on emission rate (and thus removal efficiency), the implementation of alternative 3 would result in the lowest air quality impact. 
All three alternatives use standalone dry processes. The only waste associated with these systems would be the spent filters. Alternative l has the largest volume of waste to be disposed of (i.e., the sand) and therefore poses the greatest potential environmental impact (landfill space and possible contamination) of the alternatives. Alternative 3 would produce less waste material than alternative 2 , although only relative quantities can be estimated at this time.

\subsection{ENERGY}

Energy requirements for the three alternatives are associated with operating a sufficiently large exhaust $f a n(s)$ to overcome the pressure drop of each system (as the final exhaust temperature of $26.6^{\circ} \mathrm{C}\left[80^{\circ} \mathrm{F}\right]$ is within the operating range of the filters). Based on the anticipated pressure drops of the initial control stage of each alternative (see Appendix B) alternative 2 (sand filter pressure drop $=11 \mathrm{in}$. WC) would have the highest energy impacts of the alternatives, followed by alternative 1 (fiber filter pressure drop $=8 \mathrm{in}$. WC) and alternative 3 (HEPA pressure drop $=$ 4 inches $W C$ ).

\subsection{ECONOMIC}

Installed costs of the three alternatives are presented below, based on previously installed exhaust cleaning systems at various nuclear fuel reprocessing plants (Burchsted et a1. 1976).

Alternative 1 (deep-bed fiber and HEPA)

Alternative 2 (deep-bed sand filter only)

Alternative 3 (two-stage HEPA)
Cost $\left(\$ / \mathrm{ft}^{3} / \mathrm{min}\right)$ 30.34

46.88 (cost of additiona)

7.43

These cost estimates show that alternative 3 costs only about $24 \%$ of alternative 1 and $16 \%$ of alternative 2 (percentage would be less if costs of HEPA were include in alternative 2). Although operating costs such as utilities, maintenance, operations, service life, and consumables are not available, it has been shown that alternative 2 has the highest utility cost ( 1 argest fan requirements) and higher overall operating costs than alternative 1 (Moore and Fullam 1984). Alternative 1 has the second highest utility cost, and alternative 3 has the lowest utility cost. On the other hand, Alternative 3 is expected to have higher maintenance costs than alternative 2 because of the frequency of filter changeouts.

\subsection{SUMMARY}

Alternative 3 is considered to be the BARCT for the final FAA exhaust. Its use of available proven control methods for reducing radionuclides is 
confirmed by comparing its effectiveness to the alternatives. It is the most cost effective alternative, having the lowest capital and operating costs. Alternative 3 also has the lowest energy consumption of the three systems evaluated.

\subsection{ANALYSIS OF PRESENT AIR QUALITY AT THE PROPOSED SOURCE LOCATION}

Radionuclides are the only regulated pollutants of concern projected to be emitted by the proposed source in significant quantities as defined by PSD regulations. Therefore, the analysis of present air quality at the proposed site has been limited to impacts of ambient radionuclide concentrations.

The following data was taken from PNL-6825, Hanford Site Environmental Report for Calendar Year 1988 (Jacquish 1989), a copy of which is provided to the Department of Ecology upon publication. The AIRDOSE-EPA (Clean Air Act Code) computer code was used by PNL to develop the offsite dose data.

Radiological airborne emissions for 1988, from the proposed project site (400 Area) as reported in the Hanford Site Environmental Report for Calendar Year 1988 were as follows:
$90 \mathrm{Sr}$
131 I
$2.1 \mathrm{E}-05 \mathrm{Ci}$
${ }^{41} \mathrm{Ar}$
$1.0 \mathrm{E}-05 \mathrm{Ci}$
$3.7 \mathrm{E}+01 \mathrm{Ci}$

These radionuclides combine for an effective dose equivalent (whole body dose) to the maximally exposed offsite individual of $2 \times 10^{-4} \mathrm{mR}$. The same report states that the effective dose equivalent to the maximally exposed offsite individual from all Hanford Site operations air emissions is $0.3 \mathrm{mR}$. Thus, current air quality at the proposed project site is responsible for less than $0.1 \%$ of the total Hanford Site dose to the maximally exposed offsite individual.

These doses can be compared to regulatory limits set by WAC 402-80-50 and WAC 173-480-040. The cited regulations set a whole body dose 1 imit to the maximally exposed offsite individual of $25 \mathrm{mR}$. The average dose to the maximally exposed offsite individual from 400 Area airborne emissions in 1988 , is less than $0.001 \%$ of the regulatory 1 imit.

\subsection{ANALYSIS OF THE PROPOSED SOURCE ON AMBIENT AIR QUALITY}

Again, radionuclides are the only regulated pollutants of concern projected to be emitted by the proposed source in significant quantities, as significant is defined by regulations. Therefore, the analys is of the impact of the emissions from the proposed source on ambient air quality has been limited to impacts of projected ambient radionuclide concentrations. 


\subsection{MODEL DESCRIPTION}

The AIRDOSE-EPA (Clean Air Act Code) computer code was used to calculate the dose from FCFS to the maximally exposed offsite individual. Meteorological data input to the AIRDOSE-EPA code include mixing height, rainfall rate, average air temperature, vertical temperature gradient, wind direction frequency, wind speed, and atmospheric stability. This information was obtained from the data base compiled by the Hanford Meteorological Station (HMS). The HMS data on airspeed, direction, and temperature are collected at a $124.9-\mathrm{m}(410-\mathrm{ft})$ tower located on the Hanford Site between the 200 East and 200 West Areas, and at a second tower at the 400 Area. Wind speed and direction are based on hourly data collected at the 400 Area meteorological tower $10-\mathrm{m}(32.8-\mathrm{ft})$ level during the years 1983 to 1987 . Atmospheric stability was estimated from the temperature gradient between the $9.1 \mathrm{~m}$ $(30-\mathrm{ft})$ and $60.9-\mathrm{m}(200-\mathrm{ft})$ levels at the HMS for the same period using standard methods of the U.S. Nuclear Regulatory Commission. Air temperature and mixing height are also 5 -yr averages of hourly data. Temperature is measured at the tower $60.9-\mathrm{m}(200-\mathrm{ft})$ level, and mixing height data are collected by onsite acoustic sounders.

Joint frequency data, as reported by the HMS, are modified for input into AIRDOSE-EPA by conversion to true average and reciprocal average wind speeds for each direction and stability class. The meteorological data are then used to calculate $x / Q$ values for each radionuclide, which are also a function of radiological half-life and dry deposition velocity. For purposes of this calculation, deposition velocities are assigned as follows: $1.0 \times 10^{-3} \mathrm{~m} / \mathrm{s}$ for all particulate materials, $1.0 \times 10^{-2} \mathrm{~m} / \mathrm{s}$ for iodine isotopes, and zero for all gases.

Source Terms: Projected annual releases from FAA as presented in Tables 3-1 and 3-3.

Release Height: The FAA stack height is $109.7 \mathrm{~m}(359.9 \mathrm{ft})$.

Inhalation Rate: $8,500 \mathrm{~m}^{3} / \mathrm{yr}\left(300,173 \mathrm{ft}^{3} / \mathrm{yr}\right)$.

Maximally Exposed Individual: Doses were estimated for an individual living $8.7 \mathrm{~km}(5.4 \mathrm{mi})$ south of the 4862 Building.

Meteorology: The HMS data and onsite meteorological data, as discussed above.

\subsection{RESULTS OF MODELING ANALYSIS}

As stated in Section 7.0, total 1988 airborne radiological emissions from the Hanford Site resulted in $0.3 \mathrm{mR}$ dose to the maximally exposed offsite individual. Table 3-7 shows that the projected doses from FAA controlled airborne radiological emissions to the maximally exposed offsite individual are $2.2 \times 10^{-3} \mathrm{mR}$ (radon) to the whole body. The airborne radiological emissions from FAA will constitute $7.3 \times 10^{-3}$ of the whole body dose to the 
maximally exposed offsite individual resulting from airborne radiological emissions from all Hanford Site operations, based on 1988 data.

The natural background radiation dose for the Tri-Cities area of Washington State is estimated to be $300 \mathrm{mR}$. The projected dose from the FAA would constitute $7.3 \times 10^{-6}$ of natural ambient radiation.

Table 3-7. Offsite Dose Estimates for an Individual Receiving Exposure to Airborne Radiological Emissions (Actual) From Fuel Assembly Area (mR).

Whole body

\begin{tabular}{|c|c|c|c|c|c|}
\hline $220 R n+D$ & $\begin{array}{l}\text { Other } \\
\text { nuclides }\end{array}$ & Total & $220 R n+D$ & $\begin{array}{l}\text { Other nuclides } \\
\text { (bone surface) }\end{array}$ & Total \\
\hline $2.2 E-03$ & $4.8 E-06$ & $2.2 E-03$ & $8.9 E-03$ & $7.2 E-05$ & $9.0 \mathrm{E}-03$ \\
\hline
\end{tabular}

\subsection{DEMONSTRATE THAT PROPOSED EMISSIONS WILL NOT CAUSE A VIOLATION OF STATE OR NATIONAL AMBIENT AIR QUALITY STANDARDS}

Both WAC 402-80-50 and WAC 173-480-040 state the following:

The WDOE ambient standard requires that emissions of radionuclides to the air shall not cause a dose equivalent of more than $25 \mathrm{mrem} / \mathrm{y}$ to the whole body or $75 \mathrm{mrem} / \mathrm{y}$ to a critical organ of any member of the public.

National ambient air quality standards for U.S. Department of Energy (DOE) facilities, are stated in 40 CFR 61.92 as follows:

Emissions of radionuclides to air from DOE facilities shall not exceed those amounts that cause a dose equivalent of $25 \mathrm{mrem} / \mathrm{y}$ to the whole body or $75 \mathrm{mrem} / \mathrm{y}$ to the critical organ of any member of the public.

If the projected airborne radionuclide doses from $F A A$, as listed in Table 3-7, to the maximally exposed offsite individual are added to the Hanford Site 1988 total dose to the maximally exposed offsite individual, it is clear that FAA emissions will not cause a violation of either state or Federal standards.

\subsection{DEMONSTRATE THAT PROPOSED EMISSIONS WILL NOT CAUSE AN EXCURSION OVER PSD INCREMENTS FOR PARTICULATE MATTER AND SULFUR DIOXIDE}

No sulfur dioxide will be emitted by the FAA; therefore the PSD sulfur dioxide increments are not applicable. 
Because the proposed project will not meet significant emission levels for particulate matter, as significant emission levels are defined by 40 CFR 52.21 , no air quality impact analyses are required for particulate matter.

\subsection{DEMONSTRATE THAT PROPOSED EMISSIONS WILL NOT IMPAIR VISIBILITY IN A CLASS I AREA OR OTHER SENSITIVE AREAS}

Because the proposed source will not be constructed within $10 \mathrm{~km}$ (6.2 $\mathrm{mi})$ of a Class I Area, 40 CFR 52.21 states that demonstrations of visibility impact are not required.

\subsection{DISCUSS THE PROPOSED PROJECT'S EFFECTS ON REIDENTIAL OR COMMERCIAL GROWTH, VEHICULAR TRAFFIC, SOILS, VEGETATION, ACID DEPOSITION AND ANY OTHER AIR QUALITY RELATED VALUES.}

The proposed project will have no impact on residential or commercial growth or vehicular traffic because the proposed project will be located on the Hanford Site, a Federal Government public exclusion area.

The following, taken from the Hanford Site Environmental Report for Calendar Year 1988 (Jacquish 1989), describes the Hanford Site area soil and vegetation monitoring program and states the results of that program for 1988.

Surface soil and rangeland vegetation samples were collected at a number of locations during 1988, both on and off the Hanford Site. The purpose of sampling was to detect the possible build-up of radionuclides from the deposition of airborne effluents released from Hanford facilities. Samples were collected at nonagricultural, relatively undisturbed sites so that natural deposition and build-up processes would be represented.

An assessment of radionuclide contributions from Hanford operations was made by comparing results from samples collected 1) on Site with those collected off Site, 2) around the site perimeter with those collected at distant locations, and 3) downwind (primarily east and south of the Site) with those collected from generally upwind and distant locations. In addition, results obtained from each location in 1988 were compared to results obtained from the same location in previous years. Evaluations of 1988 results provided no indication of trends or increases in the concentrations of radionuclides in the offsite environment that could be attributed to Hanford operations.

A detailed description of the results of this study can be found in Chapter 4.5 of the publication cited. 
In light of the PNL study results cited above, an emissions increase on the order of magnitude discussed $\left(10^{-3}\right)$ (radon) indicates that the proposed project will have little or no measurable effect on soils or vegetation in the area. 


\section{REFERENCES}

Burchsted et al. 1976, Nuclear Air Cleaning Handbook--Design, Construction, and Testing of High-Efficiency Air Cleaning Systems for Nuclear Application, C.A. Burchsted, J.E. Kahn, and A.B. Fuller, ERDA-76-21, Oak Ridge National Laboratory, Oak Ridge, Tennessee.

Jacquish, R.E. 1989, Hanford Site Environmental Report for Calendar Year 1988, PNL-6825, Pacific Northwest Laboratory, Richland, Washington.

McDowell et al. 1976, Penetration of HEPA Filters by Alpha Recoil Aerosols, W.J. McDowe11, and F.G. Seeley (Oak Ridge National Laboratory) and M. T. Ryan (University of Lowel1, Massachusetts), 14 th ERDA Air Cleaning Conference, Sun Valley, Idaho, August 11-13, 1976.

Moore, E.B. and H.T. Fullam 1984, Control Technology for Radioactive Emissions to the Atmosphere at U.S. Department of Energy Facilities, PNL-4621-Fina1, Pacific Northwest Laboratory, Richland, Washington.

Zippler, D.B. 1974, "Evaluation of Multistage Filtration to Reduce Sand Filter Exhaust Activity," Proceedings of the 13th AEC Nuclear Air Cleaning Conference, Vol. 1, San Francisco, California, March 1975, pp. 609-619. 
DOE/RL 89-20

APPENDIX A

LITERATURE SEARCH 


\section{POLLUTION ABSTRACTS}

POLLUTION ABSTRACTS is a leading resource to environmentally related technical literature on pollution, its sources, and its control. References in Pollution Abstracts are drawn from approximately 2,500 primary sources from around the world, including books, conference papers/proceedings, periodicals, research papers, and technical reports. As of 0ctober 1988 the data base consisted of 240,000 records covering the period 1970 to the present and is updated bimonthly.

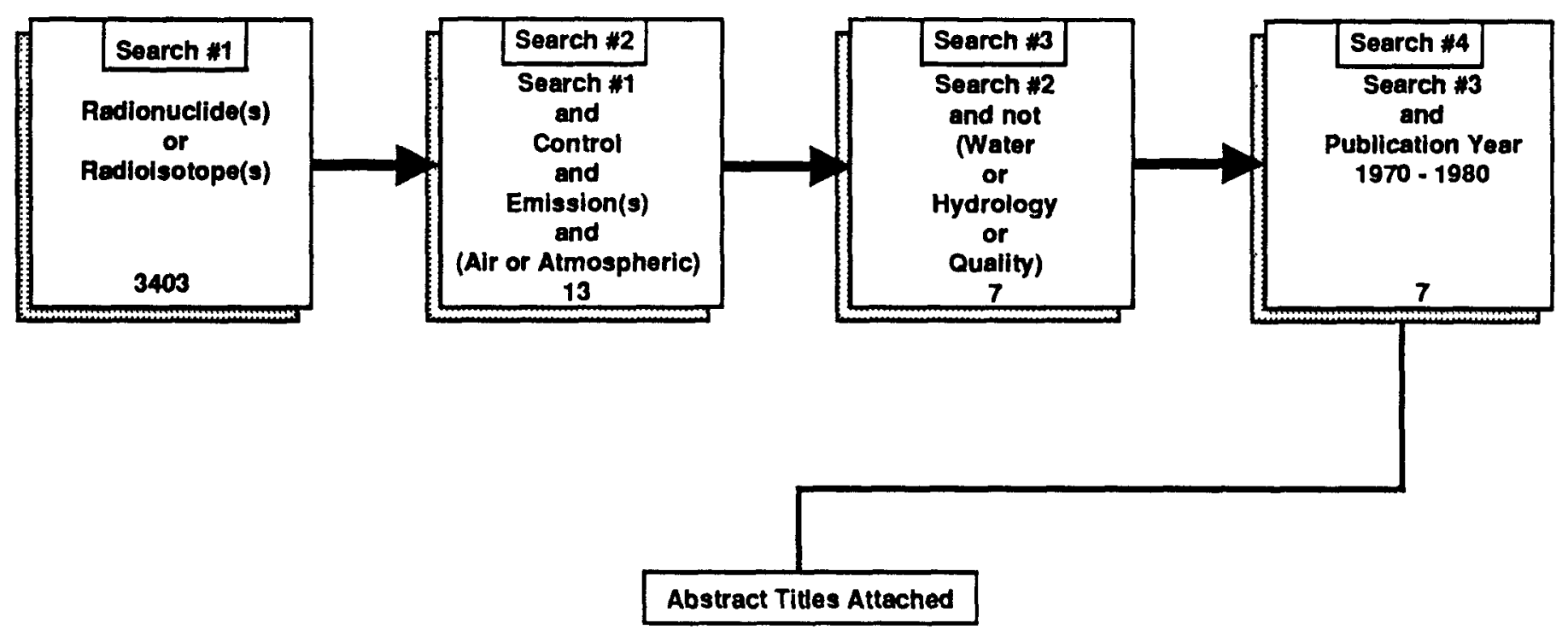


1. Partitioning of natural radionuclides in the waste streams of coal-fired utilities

Roeck, D.R.; Reavey, T.C.; Hardin, J.M.

Alliance Technol. Corp., 213 Burlington Rd., Bedford, MA 01730, USA

HEALTH PHYS VOL. 52, N0. 3, pp. 311-323, Publ.Yr: 1987

2. Radiation Protection and Environmental Monitoring for Radioactive Waste Storage in a Salt Mine

Stippler, R.; Kleimann, H.

Gesellschaft Strahlen \& Umweltforschung mbH, Muenchen FRG

7th Regional Cong. IRPA/13th Annl. Conf. Fachverband fur Strahlenschutz

"Radioactive Wastes" Cologne, FRG 16-19 0ct. 1979 IN "PROC. 7TH

REGIONAL CONG. IRPA/13TH ANNL. CONF. FACHVERBAND FUR

STRAHLENSCHUTZ PUb1.Yr: 1979

L.F.FRANZEN, GRS, POSTFACH 101650 , D-5000 KOLN 1, FRG

3. Radioactive airborne effluents from the radiopharmaceutical industry.

Leventhal, L.; Chakoff, E. H.; Savage, E.; Strom, K. A.; Trent, M. G.; Fielder, D. R.; Cehn, J.I.

LFE-EAL, Richmond, CA 94804

Twenty-fourth annual meeting of the Health Physics Society Philadelphia, Pennsylvania Jun $24-29,1979$

Health Physics Society

HEALTH PHYSICS 37(6), 799-800, Publ.Yr: Dec 1979 Coden: HLTPAO

DOC Type: CONFERENCE PAPER

4. (Ensuring radiation safety of the population in connection with the development of the atomic energy industry).

Vorob'ev, E. I. -

Acad. of Medical Sciences USSR, Leninsky Prospekt 14, Moscow V-71, USSR

GIGIENA I SANITARIYA No. 6, 3-7, Publ.Yr: 1979 Coden: GISAAA

Languages: Russian

DOC Type: JOURNAL PAPER

5. Bioindication of the aerosol products of nuclear fission with the aid of the needles of the common pine tree.

Piskunov, L. I.; Treiger, S. I.

ATOMNAIA ENERGIIA 45(3), 223-225, Publ.Yr: Sep 1978 Coden: AENGAB

SOVIET ATOMIC ENERGY 45(3), 913-915, Coden: SATEAZ

DOC Type: JOURNAL PAPER

6. The remote control and monitoring system for nuclear reactors operational in Bavaria. Dornstetter, $P$.

DORNIER POST No. 2, 9-14, Publ.Yr: 1979 Coden: DOPOAC

ISSN: $0012-5563$

DOC Type: JOURNAL PAPER 
7. Experience practique du traitement des effluents gazeux a l'usine de $\backslash$ retraitement

Eurochemic. (Operational experience of gaseous effluent treatment of the Eurochemic reprocessing plant).

Osipenco, A.; Detilleux, E.

Eurochemic, $2400 \mathrm{Mol}$, Bel.

Seminar on radioactive effluents from nuclear fuel reprocessing plants Karlsruhe, FRG

Nov. 22-25, 1977

Radioactive effluents from nuclear fuel reprocessing plants: Seminar proceedings

Publ.Yr: 1978 pp. 71-80

Publ: Luxembourg Commission of the European Communities

Eng., Fr., Ger. sums.

Languages: French

Doc Type: CONFERENCE PAPER 
NTIS

NTIS is produced by the National Technical Information Service of the U.S. Department of Commerce. The data base consists of Government- sponsored research, development, and engineering reports as well as other analyses prepared by Government agencies, their contractors, or grantees. The data base contains 1.4 million records as of January 1989 covering dates from 1964 to the present and is updated biweekly.

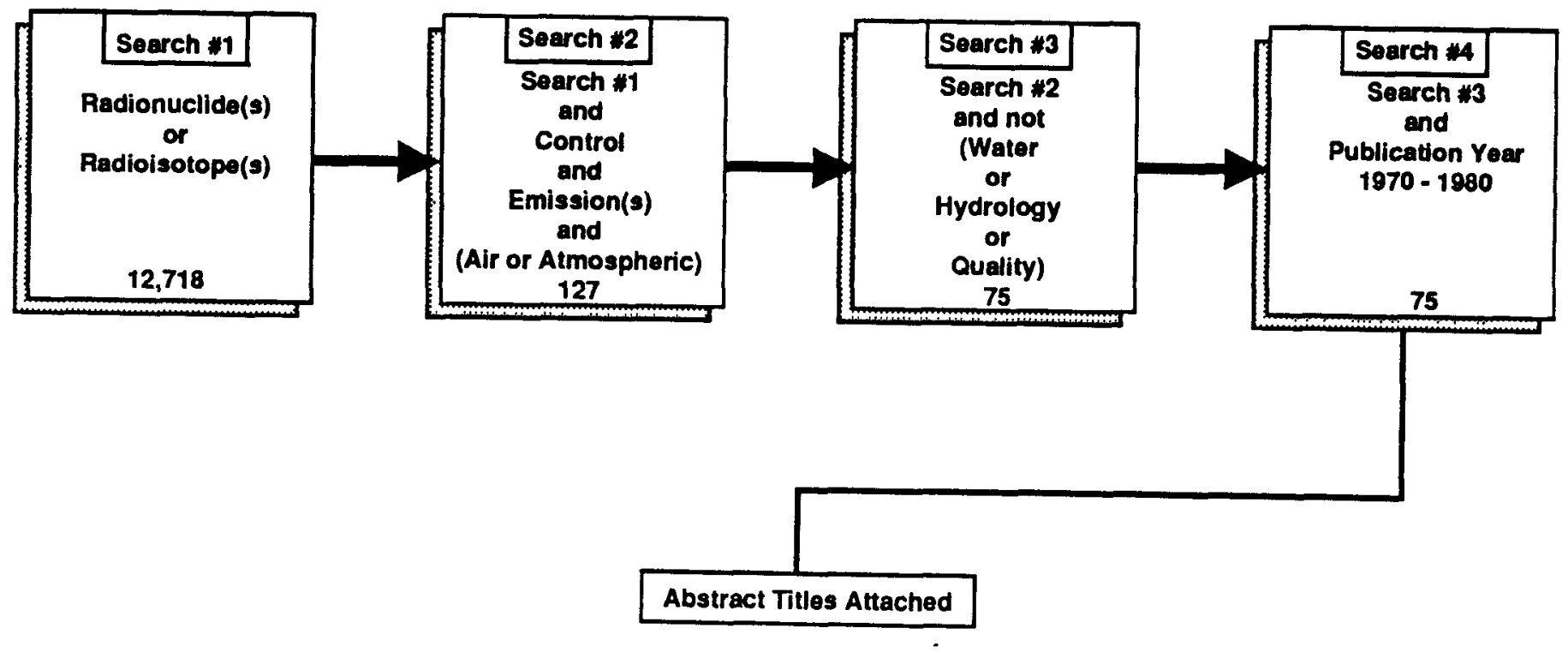


1. Second Progress Report for the WERF (Waste Experimental Reduction Facility) Incinerator

Dalton, J.D.

$E G$ and $G$ Idaho, Inc., Idaho Falls.

Sponsor: Department of Energy, Washington, DC.

Report No.: EGG-WM-8154

Jun $8859 p$

2. Measurement and Modeling of External Radiation During 1985 from LAMPF (Los Alamos Meson Physics Facility) Emissions

Bowen, B. M.; 01 sen, W. A.; Chen, I.; Van Etten, D. M. Los Alamos National Lab., NM.

Sponsor: Department of Energy, Washington, DC.

Report No.: LA- $11150-$ MS

Nov $8731 p$

3. Radiation Dose Resulting from the Releases of Fly Ash in the Environment

Koester, H.W.; Leenhouts, H. P.; Frissel, M. J.

Ministerie van Volkshuisvesting, Ruimtelijke Ordening en Milieubeheer, The Hague (Netherlands). Directie Stralenbescherming.

Report No.: VROM-DSB-86-21; VROM-60250/6-86

Jun $86102 p$

Languages: Dutch

4. Waldsterben, natuerliche und kerntechnisch erzeugte Radioaktivitaet. Gutachten zumoeglichen Zusammenhaengen zwischen der Emission radioaktiver Edelgase auskerntechnischen Anlagen und dem Waldsterben und zum Vergleich natuerlicher undkuenstlicher Radioaktivitaet. Forest decline, natural and technically generated radioactivity. Expertise on possible relations between effluent radioactive rare gas from nuclear plants and forest decline and regarding the comparability of natural and artificial radioactivity)

Teufel, D.

Institut fuer Energie- und Umweltforschung e.V., Heidelberg (Germany, F.R.).

Report No.: IFEU--25

Jun $8342 p$

Languages: German

5. OLDES - ein KFUE-integrierbares System zur Diagnose und Prognose der Strahlenexposition bei erhoehten Emissionen aus kerntechnischen Anlagen. (OLDES - an on-line dose evaluation system that $c$ an be integrated into the remote monitoring system of nuclear power stations for additional monitoring and prognostic assessment in case of major accidental activity release)

Witt, H.; Brenk, H.D.; Kruschel, K.P.; Knaup, A.G.

Bundesministerium fuer Umwelt, Naturschutz und Reaktorsicherheit, Bonn (Germany, F.R.).

Report No.: BMU--1986-135

1986 228p

Languages: German 
6. Atmospheric Tracer Study of the Emissions from the University of Michigan Cyclotron/PET Facility (Thesis) Scofield, P. A.

Michigan Univ., Ann Arbor.

Sponsor: Oak Ridge Associated Universities, Inc., TN.; Department of Energy, Washington, $D C$.

Report No.: DOE/OR/00033-T308

23 Mar $86145 p$

7. Influence of Industry on Pollution of the Environment and Human Population with Natural Radionuclides and Heavy Metals Jaworowski, $Z$.

Central Lab. for Radiological Protection, Warsaw (Poland). Report No.: CLOR-116/D $1982152 p$

8. Overview of Airborne Radioactive Emissions at Los Alamos National Laboratory

Guevara, F. A.; Dvorak, R. F. Los Alamos National Lab., NM.

Sponsor: Department of Energy, Washington, $D C$. Report No.: LA-UR-87-1103; CONF-870620-2

$198728 p$

9. Calculation Program of Consequences Developed for the Crisis Technical Center of the Protection and Nuclear Safety Institut

Crabol, B.; Manesse, D.; Bouscatie, F.

CEA Centre d'Etudes Nucleaires de Fontenay-aux-Roses (France). Dept. d'Analyse de Surete.

Report No.: CEA-CONF-8586; CONF-8509130-5; CEA-DAS-.-220

Sep $8515 p$

Languages: French Document Type: Conference proceeding

10. Berechnung der Strahlenexposition durch Ableitungen radioaktiver Stoffe mit der Abluft aus Anlagen von Isotopenanwendern (Calculation of Radiation

Exposure from Emissions of Radioactive Materials with Off-Air from Facilities Using Isotopes)

Haubelt, R.; Fischer, P.; Sonnabend, H. R.

Bundesgesundheitsamt, Neuherberg (Germany, F.R.). Inst. fuer

Strahlenhygiene.

Report No.: ISH-46; ISBN-3-924403-21-X

Aug $8435 p$

Languages: German 
11. Untersuchungen ueber die Emission von Eisen-55 und Nickel-63 mit der Abluft aus Kerncraftwerken in der Bundesrepublik Deutschland in den Jahren 1979-1981 (Investigations into the Emission of Iron-55 and Nickel-63 from Off-Gas of Nuclear Power Plants in the Federal Republic of Germany in the Years 1979-198 1)

Gesewsky, P.; Vog 1, K.; Winkelmann, I.

Bundesgesundheitsamt, Neuherberg (Germany, F.R.). Inst. fuer Strahlenhygiene.

Report No.: ISH-11

Dec 82 50p

Languages: German

12. Assessment of Atmospherically-Released Radionuclides Using the Computerized Radiological Risk Investigation System

Nelson, C. B.; Sjoreen, A. L.; Miller, C. W.; Baes, III, C. F. Office of Radiation Programs, Washington, DC.

Sponsor: Oak Ridge National Lab., TN.; Department of Energy, Washington, DC.

Report No.: CONF-861165-4

$19865 p$

13. Modeling of External Radiation from the Transport of Radionuclides Across a Canyon

Bowen, B. M. ; 01 sen, W. A.; Van Etten, D.; Chen, I-1 i

Los Alamos National Lab., NM.

Sponsor: Department of Energy, Washington, DC.

Report No.: LA-UR-86-2838; CONF-861165-2

$19865 p$

14. In Situ Vitrification Large-Scale Operational Acceptance Test Analysis

Buelt, J. L.; Carter, J. G.

Battelle Pacific Northwest Labs., Richland, WA.

Sponsor: Department of Energy, Washington, DC.

Report No.: PNL -5828

May $8652 p$

15. Inhalation Toxicology Research Institute Annual Report, October 1, $1984-$.

September 30, 1985

Medinsky, M. A.; Muggenburg, B. A.

Lovelace Biomedical and Environmental Research Inst., Albuquerque, NM.

Inhalation Toxicology Research Inst.

Sponsor: Department of Energy, Washington, DC.

Report No.: LMF-114

Dec $85540 p$

16. GASPAR; Evaluation of Atmospheric Releases (NRC Code)

(Software)

Eckerman, K. F.

Oak Ridge National Lab., TN.

Report No.: ANL/NESC-963

1985 mag tape 
17. Suitability of Bees as an Indicator for Environmental Problems

Drescher, W.

Report No.: LA-TR-84-13

$198214 p$

18. Control Technology for Radioactive Emissions to the Atmosphere at U.S. Department of Energy Facilities: The LoS Alamos Meson Physics Facility

Moore, E. B.; Fullam, H. T.

Battelle Pacific Northwest Labs., Richland, WA.

Sponsor: Eastern Environmental Radiation Facility, Montgomery, AL.

Report No.: PNL-4621-ADD-1

Mar $8526 p$

19. Sensitivity, Applicability and Validation of Bi-Gaussian off-and on-Line Models for the Evaluation of the Consequences of Accidental Releases in Nuclear Facilities

Kretzschmar, J. G.; Mertens, I.; Vanderborght, B.

Commission of the European Communities, Luxembourg.

Report No.: EUR-9385

$1984177 \mathrm{p}$

20. Technology of Off-Gas Treatment for Liquid-Fed Ceramic Melters

Scott, P. A.; Goles, R. W.; Peters, R. D.

Battelle Pacific Northwest Labs., Richland, WA.

Sponsor: Department of Energy, Washington, DC.

Report No.: PNL -5446

May $85113 p$

21. Control Technology for Radioactive Emissions to the Atmosphere at US Department of Energy Facilities: The Los Alamos Meson Physics Facility.

Addendum 1

Moore, E. B.; Fullam, H. T.

Battelle Pacific Northwest Labs., Richland, WA.

Sponsor: Department of Energy, Washington, DC.

Report No.: PNL-4621-ADD. 1

Mar $8522 p$

22. Calculation of Radionuclide Migration Via the Air and Food Pathway and of the Potential Radiation Exposure Resulting from Surface, Facilities for Nuclear Waste Management. Summarizing Interim Report. Pt. 4

Hahn-Meitner-Inst. fuer Kernforschung Berlin G.m.b.H. (Germany, F.R.). Project Sicherheitsstudien Entsorgung.

Report No.: INIS-MF-9188

May 83 92p

Languages: German 
23. Control Technology for Radioactive Emissions to the Atmosphere at US Department of Energy Facilities

Moore, E. B.

Battelle Pacific Northwest Labs., Richland, WA.

Sponsor: Department of Energy, Washington, DC.

Report No.: PNL-4621-FINAL

Oct $84612 p$

24. Radionuclides: Background Information Document for Final Rules.

Volume 2 (Final rept)

Office of Radiation Programs, Washington, DC.

Sponsor: PEI Associates, Inc., Cincinnati, OH.; Battelle Columbus Labs.,

$\mathrm{OH}$.; Kilkelly Environmental Associates, Inc., Raleigh, NC.

Report No.: EPA/520/1-84/002/2

Oct $84441 p$

25. Radionuclides: Background Information Document for Final Rules.

Volume 1 Office of Radiation Programs, Washington, DC.

Sponsor: PEI Associates, Inc., Cincinnati, OH.; Battelle Columbus Labs., OH.;

Kilkelly Environmental Associates, Inc., Raleigh, NC.

Report No.: EPA/520/1-84/022/1

Oct $84282 p$

26. Scientific Critique of Available Models for Real-Time Simulations of Dispersion (Technical rept.)

Lewellen, W. S.; Sykes, R. I.

Aeronautical Research Associates of Princeton, Inc., NJ.

Sponsor: Nuclear Regulatory Commission, Washington, DC. Office of Nuclear Regulatory Research.

Report No.: ARAP-472

Mar $85170 p$

27. Method of Instantaneous Approximation of the Atmospheric Dispersion Doury, A.

CEA Centre d'Etudes Nucleaires de Fontenay-aux-Roses (France).

Inst. de Protection et de Surete Nucleaire.

Report No.: CEA-CONF-7187; DAS-43; CONF--831032--4

Dec $8312 p$

Languages: French Document Type: Conference proceeding

28. Continuous Vent Sampler for Monitoring Radionuclide Emissions

Orlett, M. J.

Goodyear Atomic Corp., Piketon, $\mathrm{OH}$. Chemical and Materials

Technology Dept.

Sponsor: Department of Energy, Washington, DC.

Report No.: GAT-T-3282; CONF-841187-15

19 oct $8415 p$ 
29. Uranium Content in Surface Air in Vienna During the Years $1963 / 64$ and 1974 - 1978

Irlweck, K.; Pichlmayer, F.

Oesterreichisches Forschungszentrum Seibersdorf G.m.b.H.

Report No.: OEFZS-4187; ST-103/82; PH---351/82

Nov $8214 p$

Languages: German

30. Recent Field Studies of Dry Deposition to Surfaces in Plant Canopies

Lindberg, S. E.; Lovett, G. M.; Bondietti, E. A.; Davidson, C. I.

Oak Ridge National Lab., TN.

Sponsor: Carnegie-Mellon Univ., Pittsburgh, PA. Dept. of Civil

Engineering.; Department of Energy, Washington, DC.

Report No.: CONF-840612-17

$198420 p$

31. EFFDOS - A FORTRAN-77-Code for the Calculation of the Effective Dose Equivalent

Baer, M.; Honcu, S.; Huebschmann, W.

Kernforschungszentrum Karlsruhe G.m.b.H. (Germany, F.R.). Hauptabteilung

Sicherheit.

Report No.: KFK-3631

Jan $8466 p$

Languages: German

32. Radionuclides: Regulatory Impact Analysis of Emission Standards for Elemental Phosphorus Plants

Faucett (Jack) Associates, Inc., Chevy Chase, MD.

Sponsor: Environmental Protection Agency, Washington, DC.

Report No.: EPA/520/1-84/025

Oct $8484 p$

33. RETADD-II: A Long-Range Atmospheric Trajectory Model with Consistent

Treatment of Deposition Loss and Species Growth and Decay

Murphy, B. D.; Ohr, S. Y.; Begovich, C. L.

Oak Ridge National Lab., TN.

Sponsor: Department of Energy, Washington, DC.

Report No.: ORNL/CSD-99

Aug $8437 p$

34. Mobilization of Heavy Metals from Fossil-Fuelled Power Plants, Potential

Ecological and Biochemical Implications. Part 4. Assessment Studies of

the European Situation

Sabbioni, E.; Goetz, L.

Commission of the European Communities, Ispra (Italy). Joint Research Centre.

Report No.: ISBN-92-825-3839-7; EUR-6998-EN-PT-4

$1983179 p$ 
35. Survey of Five Utility Boilers for Radionuclide Emissions (Final rept.) Roeck, D. R.; White, M. 0.; Kiddie, A. M.; Young, C.W. GCA Corp., Bedford, MA. GCA Technology Div. Sponsor: Office of Radiation Programs, Washington, DC. Report No.: GCA-TR-83-56-G

Dec 83 150p

36. Emitted and Decayed Values of Radionuclides in Gaseous Wastes Discharged to the Atmosphere from the Separation Facilities Through Calendar Year 1972

Anderson, J. D.

Atlantic Richfield Hanford Co., Richland, WA. Sponsor: Department of Energy, Washington, $D C$.

1 Mar $749 p$

37. Airborne Emission Control Technology for the Elemental Phosphorus Industry (Final rept.)

Stula, R. T.; Belanger, R. E.; Clary, C. L.; May, R. F.; Spaeth, M. E. Science Applications, Inc., La Jolla, CA.

Sponsor: Environmental Protection Agency, Washington, DC. Jan $84412 p$

38. Balance of the Tropospheric 0zone and Its Relation to Stratospheric

Intrusions Indicated by Cosmogenic Radionuclides. Part IX and Part $X$. Combined Annual Report, 1 November 1977-31 0ctober 1979

Reiter, R.; Kanter, H. J.; Jaeger, H.; Munzert, K.

Fraunhofer-Gesellschaft zur Foerderung der Angewandten Forschung e.V., Garmisch-Partenkirchen (Germany, F.R.). Inst. fuer Atmosphaerische Umwel t forschung.

Sponsor: Department of Energy, Washington, DC.

Report No.: DOE/ET/03425-23/24

Aug $8372 p$

39. GASPAR; Evaluation of Atmospheric Releases

(Software)

Eckerman, K. F.; Lash, D. G.; Shields, J. A.

Oak Ridge National Lab., TN.

Sponsor: Nuclear Regulatory Commission, Washington, DC. Div. of

Automatic Data Processing.; Department of Energy, Washington, DC.

Report No.: ANL/NESC-963

1984 mag tape

40. Estimation of Radionuclide Releases from Specific Large Coal-Fired Industrial and Utility Boilers

Greiner, N. R.; Williams, M. D.; Wagner, P.

Los Alamos National Lab., NM.

Sponsor: Department of Energy, Washington, DC.

Report No.: LA-9845-MS

Aug $83227 p$ 
41. Radionulides in Western Coal. Final Report Abbott, D. T.; Styron, C. E.; Casella, V. R. Monsanto Research Corp., Miamisburg, OH. Mound. Sponsor: Department of Energy, Washington, DC. Report No.: MLM-3026

23 Sep $8328 p$

42. Background Information on Sources of Low-Level Radionuclide Emissions to Air

Corbit, C. D.; Herrington, W. N.; Higby, D. P.; Stout, L. A.; Corley, J. P.

Battelle Pacific Northwest Labs., Richland, WA.

Sponsor: Department of Energy, Washington, DC.

Report No.: PNL-4670

Sep $8349 p$

43. Choosing the Best Meteorological Conditions for Atmospheric Diffusion Experiments at the Angra Site

Nicolli, D.; Thomas, P.

Commisao Nacional de Energea Nuclear de Brasil, Rio De Janeiro

Report No.: CNEN-DIN-01/83

Jan $8319 p$

44. Inhalation Toxicology Research Institute. Annual Report, October 1 , 1981 -September 30, 1982

Snipes, M. B.; Marshal1, T. C.; Martinez, B. S.

Inhalation Toxicology Research Inst., Albuquerque, NM.

Sponsor: Department of Energy, Washington, DC.

Report No.: LMF-102

Dec 82 589p

45. Atlantic Coast Unique Regional Atmospheric Tracer Experiment (ACURATE) Schubert, J. F.; Heffter, J. L.; Mead, G. A.

Du Pont de Nemours (E.I.) and Co., Aiken, SC. Savannah River Lab.

Sponsor: Department of Energy, Washington, DC.

Report No.: DP-1651

May $8316 p$

46. Background Information Document Proposed Standards for Radionuclides (Draft rept)

Office of Radiation Programs, Washington, DC.

Report No.: EPA-520/1-83-001

Mar $83390 p$

47. Emmissions of Naturally Occuring Radioactivity: Stauffer Elemental Phosphorus Plant

Andrews, Veron $E$.

Office of Radiation Programs-Las Vegas Facility, NV.

Report No.: EPA-520/6-82-019

Nov $8236 p$ 
48. Plutonium-Aerosol Emission Rates and Human Pulmonary Deposition Calculations for Nuclear Site 201, Nevada-Test Site Shinn, J. H.; Homan, D. N. Lawrence Livermore National Lab., CA. Sponsor: Department of Energy, Washington, DC. Report No.: UCRL-53301 21 Jun $8221 p$

49. ETADDII: Modeling Long-Range Atmospheric Transport of Radionuclides Murphy, B. D. Oak Ridge National Lab., TN.

Sponsor: Department of Energy, Washington, DC .

Report No.: CONF-820609-47

$198229 p$

50. Scaled-Up Testing of Alternative Trapping Agents for Radioactive Constituents in Plant Vent Streams

Saraceno, A. J.; Reiter, N. F.

Goodyear Atomic Corp., Piketon, $\mathrm{OH}$.

Sponsor: Department of Energy, Washington, DC.

Report No.: GAT-T-3115; CONF-820418-3

$198222 p$

51. SESAM: A Model for the Calculation of Radiation Exposure by Emission of Pollutants with the Exhaust Air in the Case of a Multi-Source Situation Ehrlich, H. G.; Vogt, K. J.; Brunen, E.

Oak Ridge Nationa1 Lab., TN.

Sponsor: Department of Energy, Washington, DC.

Report No.: ORNL-TR-4794

Aug $8081 p$

52. POPFOOD - A Computer Code for Calculating Ingestion Collective Doses from Continuous Atmospheric Releases

Hotson, J.; Stacey, A.; Nair, S.

Central Electricity Generating Board, Berkeley (England). Berkeley Nuclear Labs.

Jul $8047 p$

53. MILDOS - A Computer Program for Calculating Environmental Radiation Doses from Uranium Recovery Operations

(Research rept.)

Strenge, D. L.; Bander, T. J.

Battelle Pacific Northwest Labs., Richland, WA.

Sponsor: Nuclear Regulatory Commission, Washington, DC. Div. of Waste Management

Report No.: PNL-3767

Apr $81179 p$ 
54. Investigations of the Emission of Radionuclides from Coal Fired Power Plants. Methods of Analys is and Measured Results for a Hard Coal Power Plant and a Brown Coal Power Plant

Chatterjee, B.; Hoetzl, H.; Rosner, G.; Winkler, R.

Gesellschaft fuer Strahlen- und Umweltforschung m.b.H., Neuherberg bei

Munich (Germany, F.R.). Inst. fuer Strahlenschutz.

Feb 80 44p

Languages: German

55. Sources of 0zone and Sulfate in Northeastern United States. Annual Progress Report

Husain, L.

New York State Dept. of Health, Albany.

Sponsor: Health Research, Inc., Albany, NY.; Department of Energy, Washington, $D C$.

0 Jun $80225 p$

56. Air Pathway 3

Hessisches Ministerium fuer Wirtschaft und Technik, Wiesbaden (Germany, F.R.).

Report No.: CONF-770778-

$1977176 p$

Languages: German Document Type: Conference proceeding

57. LIGA - A Program to Calculate the Local Individual gamma Submersion Dose Due to Waste Air Plumes of Nuclear Facilities

Brenk, H. D.; Rohloff, F.; Brunen, E.; Geiss, H.; Vogt, K. J.

Kernforschungsanlage Juelich G.m.b.H. (Germany, F.R.). Zentralabteilung Strahlenschutz.

Jan $7977 p$

Languages: German

58. Air Pathway 3

Hessisches Ministerium fuer Wirtschaft und Technik, Wiesbaden (Germany, F.R.). Report No.: CONF-770778-1977

$176 p$

59. Characterization of Gaseous and Particulate Effluents from the Nuclear Vitrification Project

Goles, R.W.; Hamilton, D. C.; Brauer, F. P.; Rieck, Jr., H. G.;

Robertson, D. M.

Battelle Pacific Northwest Labs., Richland, WA.

Sponsor: Department of Energy.

oct $7939 p$ 
60. Pyrotechnical Production of Labelled Aerosols and Their Use in the Ground Atmosphere

Kuehn, W. K. G.; Alps, W.

Zentralstelle fuer Atomkernenergie-Dokumentation, Eggenstein-

Leopoldshafe n (Germany, F.R.).

Report No.: CONF-7710173-6

1977 7p

Languages: German Document Type: Conference proceeding

61. Source Category Survey: Uranium Refining Industry

(Final rept.)

Stelling III, John H. E.

Radian Corp., Durham, NC.

Sponsor: Environmental Protection Agency, Research Triangle Park, NC.

Office of Air Quality Planning and Standards.

Report No.: EPA-450/3-80-010

May $8025 p$

62. Computer Program for Calculating the Radiological Consequences of

Shorttime Radioactive Releases from Nuclear Installations

Boeck, H.; Strubegger, M.

Atominstitut der Oesterreichischen Univ., Vienna.

Sep 78 38p

Languages: German

63. Diffusion and Exhalation of Radon from Uranium Tailings

Silker, W. B.; Heasler, P. G.

Battelle Pacific Northwest Labs., Richland, WA.

Sponsor: Nuclear Regulatory Commission, Washington, DC. Office of Nuclear

Regulatory Research.; Department of Energy, Washington, DC .

Report No.: PNL-3207

Mar $80136 p$

64. Radiological Impact Caused by Emissions of Radionuclides into Air in the United States: Preliminary Report

(Technical rept)

Office of Radiation Programs, Washington, $D C$.

Report No.: EPA/520/7-79-006

Aug $7948 \mathrm{lp}$

65. Physical and Chemical Characterization of Aerosol Emissions from

Coal-Fired Power Plants

Ondov, J. M.; Biermann, A. H.

Cal ifornia Univ., Livermore. Lawrence Livermore Lab.

Sponsor. Department of Energy.

Report No.: CONF-790458-3

25 Jun $7916 p$ 
66. Assessment of the Radiological Impact of Coal Utilization. I. Preliminary Studies on Western Coal

Styron, C. E.; Casella, V. R.; Farmer, B. M.; Hopkins, L. C.; Jenkins, P. H.

Mound Facility, Miamisburg, $\mathrm{OH}$.

Sponsor: Department of Energy.

12 Feb 79 100p

67. Application-Oriented Concept for Calculating Environmental Impacts

Through Exhaust Air Emissions from Nuclear Facilities for Sites in the Federal Republic of Germany

Brenk, H. D.

Kernforschungsanlage Juelich G.m.b.H. (Germany, F.R.). Zentralabteilung Strahlenschutz.

Sponsor: Technische Hochschule, Aachen (Germany, F.R.).

Feb $78225 p$

Languages: German Document Type: Thes is

68. Analysis for Radionuclides in SRC and Coal Combustion Samples (Final rept. Nov 77-Jul 78)

Koester, Pamela A.; Zieger, Warren $\mathrm{H}$.

Hittman Associates, Inc., Columbia, MD.

Sponsor: Industrial Environmental Research Lab., Research Triangle Park, NC.

Report No.: EPA/600/7-78/185

Sep $7833 p$

69. AREAS: A Computer Code for Estimating Air Pollutant Concentrations from Dispersed Sources

Moore, R. E.

Oak Ridge National Lab., Tenn.

Sponsor: Department of Energy.

May $7842 p$

70. Methodology for Assessing Dose Commitment to Individuals and to the Population from Ingestion of Terrestrial Foods Contaminated by Emissions from a Nuclear Fuel Reprocessing Plant at the Savannah River Plant

Ng, Y. C.; Phillips, W. A.; Ricker, Y. E.; Tandy, R. K.; Thompson, S. E.

California Univ., Livermore. Lawrence Livermore Lab. Sponsor: Department of Energy.

$15 \operatorname{Mar} 7873 p$

71. Area Source Radiological Emission Analysis Code (AREAC)

Michlewicz, David

Office of Radiation Programs, Washington, D.C. Environmental Analysis

Div. Report No.: ORP/EAD-76/6

oct 76 63p 
72. Preliminary Assessment of the Impact of Radionuclides in Western Coal on Health and Environment

Styron, C. E.

Mound Lab., Miamisburg, Ohio.

Sponsor: Department of Energy.

Report No.: CONF-780109-1

$19786 p$

73. Interlaboratory Comparison of Neutron Activation and Atomic Absorption Analyses of Size-Classified Stack Fly Ash

Ondov, J. M.; Ragaini, R. C.; Heft, R. E.; Fisher, G. L.; Silberman, $D$.

California Univ., Livermore. Lawrence Livermore Lab.

Sponsor: Energy Research and Development Administration.

Report No.: CONF-760985-2

29 Jun $7714 p$

74. AIREM Program Manual. A Computer Code for Calculating Doses, Population Doses, and Ground Depositions Due to Atmospheric Emissions of Radionuclides Final rept.)

Martin, Jr., J. A.; Nelson, J. C. B.; Cuny, P. A.

Office of Radiation Programs, Washington, D.C. Field Operations Div.

Report No.: EPA-520/1-74-004

May $74134 p$

75. Industrial Wood/Coal Co-Utilization in the Northeast: Technology Assessment and Case Studies. Final Report

White, A. L.

Boston Planning Group, Inc., MA.

Sponsor: Department of Energy, Washington, DC.

Report No.: DOE/OR/21389-T3

Sep $8541 p$ 
DOE/RL 8920

APPENDIX B

ALTERNATIVE CONTROL EQUIPMENT 


\section{APPENDIX B}

\section{ALTERNATIVE CONTROL EQUIPMENT}

\section{HIGH-EFFICIENCY PARTICULATE AIR (HEPA) FILTER}

\section{Pollutants Controlled:}

Particulate matter

\section{Process Description:}

By definition, a HEPA filter is a disposable, extended medium, dry-type filter having (1) a minimum particle removal efficiency of greater than $99.97 \%$ for $0.3-\mu \mathrm{m}$ particles; (2) a maximum resistance when clean of $250 \mathrm{~Pa}$ ( 1 in. water column (WC) when operated at rated air flow capacity; and (3) a rigid casing extending the full depth of the medium. The core of the HEPA is generally made by pleating a continuous web of fiberglass paper back and forth over corrugated separators that add strength to the core and provide air passages between the pleats. The core is then sealed in a wood or steel casing (frame) with an elastomeric sealant. The filter paper itself is composed of very fine (submicron) glass fibers in a matrix of larger $(1-4-\mu \mathrm{m})$ fibers and held with an organic binder. Increased particle removal can be attained by using HEPA filters in series.

\section{Current Applications:}

Filtration for "cleanroom" environments

Nuclear industry ventilation systems

Design Characteristics/Performance:

Efficiencies of at least $99.97 \%$ for $0.3-\mu \mathrm{m}$ or smaller particles

Relatively low pressure drop ( 1 in. WC new, 4 in. WC at replacement)

System Advantages:

Extremely high efficiency Simple design; no moving parts

System Disadvantages:

Spent filters become solid waste Must be kept dry to avoid fouling

Somewhat fragile

\section{References:}

Fluor 1988

EPA 1984

Burchsted 1976 
ALTERNATIVE CONTROL EQUIPMENT

\section{DEEP-BED SAND FILTER}

\section{Pollutants Controlled:}

Particulate matter

\section{Process Description:}

Sand filters are deep beds (several feet thick) of rock, gravel, and sand constructed in layers graded with about 2 to 1 variation in granule size from layer to layer. Gas flow is upward through the bed, with the granules decreasing in size in the direction of flow. A top layer of moderately coarse sand is added to prevent fluidization. Below the sand bed is a course of hollow tiles that serve to distribute the gas evenly throughout the bed. In principle, the larger granules remove most of the large particles and particulate mass, while the layers of finer sands provide high efficiency removal.

\section{Current Applications:}

Radiochemical processing facility ventilation systems

Design Characteristics/Performance:

Pressure drop of a 7-layer, $3 \mathrm{in.}$ WC down to 50 -mesh filter is 7-11 in. WC Removal efficiency fabricated to be $99.95 \%$ for $0.3-\mu \mathrm{m}$ particles

System Advantages:

Low maintenance

Fire resistant

High heat capacity

System Disadvantages:

High initial cost Large space requirement

References:

Burchsted 1976
Can accommodate large fluctuations in gas flow Inert to chemical attack

High pressure drop

Spent sands become solid waste 
ALTERNATIVE CONTROL EQUIPMENT

\section{DEEP-BED GLASS-FIBER FILTER}

Pollutants Controlled:

Particulate matter

\section{Process Description:}

Deep-bed glass-fiber filters are deep ( 8 to 84 in.) beds of compacted fiberglass insulating wool contained in stainless steel boxes having opaque sides and perforated screens at the top and bottom. Different packing densities are used for each stage of the deep-bed filter (much like the sand filter), with the low-density packing stage at the gas inlet and the highdensity packing stage at the exit. Gas flow is in the upward direction. Although various fibers were tested, only one was found to have sufficient curl to resist matting. The other fibers were straight and therefore when packed together caused extremely high pressure drops at even low airflows.

Current Applications:

Radiochemical processing facility ventilation systems

Design Characteristics/Performance:

Pressure drop; 1.5 in. WC, clean filter, 8 in. WC spent filter Removal efficiency less than deep-bed sand filter (about $99.9 \%$ total)

\section{System Advantages:}

Predictable physical characteristics Relatively small space requirements Simple design

\section{System Disadvantages:}

Lower particle collection efficiency than sand filter

Relatively high pressure drop

Spent filters become solid waste

\section{References:}

Moore and Fullam 1984

Burchsted 1976 


\section{ALTERNATIVE CONTROL EQUIPMENT}

\section{PREFILTER (ROUGHING FILTER)}

Pollutants Controlled:

Particulate matter

\section{Process Description:}

Prefilters can be classified as either low (Group I), moderate (Group II), or high (Group III) efficiency filters. Group I panel filters are shallow, tray-like assemblies of coarse fibers or crimped metal mesh enclosed in a steel or cardboard casing. Group II and III filters are extended medium, dry-type units. The medium is pleated or formed as bags to increase surface area. Group II filters are effective in removing 5 - $\mu m+$ particles, while Group III filters can filter even smaller particles. Filter media can be chosen to minimize damage from corrosion.

\section{Current Applications:}

Various air filtering systems

Heating and ventilation systems

Design Characteristics/Performance:

Effective in removing large $(5-\mu \mathrm{m})$ particles

Pressure drop approximately 4 in. WC

\section{System Advantages:}

Simple design; no moving parts Low initial and operating cost Easily replaced

High dust loading capacity

\section{System Disadvantages:}

Spent filters become solid waste Somewhat high pressure drop

\section{References:}

Fluor 1988

Burchsted 1976 
ALTERNATIVE CONTROL EQUIPMENT

\section{HIGH-EFFICIENCY MIST ELIMINATOR (HEME)}

Pollutants Controlled:

Fine mists, particulate matter, aerosols

Process Description:

The HEMEs are composed of regenerable deep-bed fiber filters configured in an annular shape to remove submicrometer aerosols. Gas flows from the outside to the inside hollow core from which the clean gas exits at the top and the collected liquid exits at the sealed bottom through a drain pipe. Various fibers and other materials of construction can be selected for their resistance to gas constituents. The HEMEs can also be operated wet to allow simultaneous removal of both liquid and solid aerosols. Soluble particles become part of the liquid film and drop to the drain, while the insoluble particles lodge on the fiber and become physically bonded. Continuous or intermittent water spraying of the filter elements has been used to wash down and cleanse accumulated debris, thus extending the service life of the devices. However, water soluble compounds can migrate through the filter and become re-entrained.

\section{Current Applications:}

Acid and caustic mist removal Radiochemical plant service

\section{Design Characteristics/Performance:}

$100 \%$ removal of particles larger than $3 \mu \mathrm{m}$

$99.5 \%$ removal of particles less than $3 \mu \mathrm{m}$ in size

Pressure drops up to 25 in. WC

System Advantages:

High efficiencies

Simple design; no moving parts

Life can be extended by backwashing filter elements

System Disadvantages:

Solid and liquid wastes produced

Sensitive to process variations

High pressure drops

(i.e., upsets)

Relatively large space requirements

\section{References:}

Fluor 1988

Burchsted 1976

Scott et al. 1985 


\section{REFERENCES}

BPNL 1984, Control Technology for Radioactive Emissions to the Atmosphere at U.S. Department of Energy Facilities, Battelle Pacific Northwest Laboratories, Richland, Washington.

BPNL 1985, Iechnology of Off-Gas Treatment for Liquid-Fed Ceramic Melters, Battelle Pacific Northwest Laboratories, Richland, Washington.

Burchsted, C.A., J.E. Kahn, A.B. Fuller 1976, Nuclear Air Cleaning Handbook. Design, Construction, and Testing of High-efficiency Air Cleaning Systems for Nuclear Application, ERDA-76-21, 0ak Ridge National Laboratory, Oak Ridge Tennessee.

EPA 1984, Radionuclides-Background Information Document for Final Rules, EPA 520-1-84-022-1, U.S. Environmental Protection Agency, Office of Radiation Programs, Washington, D.C.

Fluor 1988, Melter Off-Gas Design Evaluation, Final Issue, Fluor Technology Inc., Advanced Technology Division, Irvine, California. 
CORRESPONDENCE CONTROL

Number of Copies

ONSITE

9

\section{Correspondence Control}

J. D. Bauer

D. G. Carter

R. J. Laudon

I. M. Metcalf

R. C. Nickols

K. L. Young

EDMC

Publications Service

Central. Files (3)
B3 - 15

N1 -49

$\mathrm{H} 4-50$

K6-22

B3- 02

$\mathrm{N} 1-40$

$\mathrm{H} 4-5 \mathrm{l}$

A2-24

L8-04

Distr. - 1 